Nada UNIVERSIDADE DE SÃO PAULO

PROGRAMA DE PÓS-GRADUAÇÃO EM PSICOBIOLOGIA

FACULDADE DE FILOSOFIA, CIÊNCIAS E LETRAS DE RIBEIRÃO PRETO

MARIANA REZENDE ALVES DE OLIVEIRA

Fatores cognitivos-comportamentais na hesitação à vacina e a percepção à doença: implicâncias no controle da pandemia da COVID-19

Ribeirão Preto 
MARIANA REZENDE ALVES DE OLIVEIRA

\section{Fatores cognitivos-comportamentais na hesitação à vacina e a percepção à doença: implicâncias no controle da pandemia da COVID-19}

Dissertação apresentada ao Programa de PósGraduação em Psicobiologia da Faculdade de Filosofia, Ciências e Letras de Ribeirão Preto USP como parte dos requisitos para obtenção do grau de Mestre em Ciências.

Área de concentração: Psicobiologia.

Orientador: Prof. Dr. José Aparecido da Silva

Ribeirão Preto 
Autorizo a reprodução total ou parcial deste trabalho por qualquer meio convencional ou eletrônico, para fins de estudo e pesquisa, desde que citada a fonte.

Catalogação na publicação

Serviço de Biblioteca e Documentação

Programa de Pós-Graduação em Psicobiologia

Faculdade de Filosofia Ciências e Letras de Ribeirão Preto

Universidade de São Paulo

Oliveira, Mariana Rezende Alves de

Fatores cognitivos-comportamentais na hesitação à vacina e a percepção à doença: implicâncias no controle da pandemia da COVID-19. Ribeirão Preto, 2021. 109 p.

Dissertação de Mestrado Faculdade de Filosofia Ciências e Letras de Ribeirão Preto - USP. Área de concentração: Psicobiologia.

1. Comportamento de saúde. 2. Percepção à doença. 3. Covid-19. 4. Hesitação à Vacina. 


\section{FOLHA DE APROVAÇÃO}

Mariana Rezende Alves de Oliveira

"Fatores cognitivos-comportamentais na hesitação à vacina e a percepção à doença: implicâncias no controle da pandemia da COVID-19.”.

Aprovado em:

Dissertação apresentada ao Programa de Pós-Graduação em Psicobiologia da Faculdade de Filosofia, Ciências e Letras de Ribeirão Preto - USP como parte dos requisitos para obtenção do grau de Mestre em Ciências.

Área de concentração: Psicobiologia.

Banca Examinadora

Prof. Dr.

Instituição:

Assinatura:

Prof. Dr.

Instituição:

Assinatura:

Prof. Dr.

Instituição:

Assinatura: 


\section{DEDICATÓRIA}

Dedico esse trabalho à minha mãe, Luciana, por me inspirar e mostrar o caminho dos estudos e da ciência desde cedo. 


\section{AGRADECIMENTOS}

Agradeço de forma sincera e afetuosa

A toda minha família, em especial meu pai Antônio Carlos, irmão Rafael, avó Terezinha e a minha tia Juventina pelo apoio, incentivo e compreensão durante todas as fases deste processo e da vida.

Aos meus amigos, em especial às estimadas Carolina, Ana e Amanda por todo companheirismo, torcida, disponibilidade e acolhimento neste e em tantos outros momentos significativos da vida.

Ao Professor José Aparecido por me orientar neste processo, compartilhar seu conhecimento e por me incentivar a ir além do óbvio.

A todos e todas que de forma direta e indireta estiveram comigo durante este processo ajudando, acompanhando ou torcendo por mim. 
EPÍGRAFE

"Contava as mortes que tivera na família [...] sussurrava as mágoas que elas lhe haviam causado, e, de repente, sem aviso ao universo, sem que reparasse no que dizia ou nos reparássemos nós os que escutávamos, remata, a erguer a chávena do café já sem fumo: 'Assim é a vida, mas eu não concordo.",

Fernando Pessoa 


\section{RESUMO}

Oliveira, M.R.A. (2021). Fatores cognitivos-comportamentais na hesitação à vacina e a percepção à doença: implicâncias no controle da pandemia da COVID-19. Dissertação de Mestrado, Programa de Pós-Graduação em Psicobiologia da Faculdade de Filosofia Ciências e Letras de Ribeirão Preto, Universidade de São Paulo.

A hesitação à vacina é considerada um problema de saúde pública mundial pela Organização Mundial da Saúde que permeia fatores comportamentais e cognitivos como percepção à vulnerabilidade à doença e capacidade de pensamento crítico. A hesitação à vacina é um problema no Brasil, que vem apresentando redução nas coberturas vacinais nos últimos 5 anos. A pandemia do novo coronavírus já levou à óbito mais de 600 mil brasileiros e a única prevenção existente é a vacina. O objetivo deste estudo foi avaliar e caracterizar a relação entre os fatores cognitivos e comportamentais que permeiam as percepções e atitudes em relação à vacina da COVID-19 em uma amostra da população brasileira em dois momentos da pandemia. Para tanto, foram utilizados 10 questionários que mensuravam e avaliavam os fatores intrínsecos da hesitação à vacina. A coleta se deu pela plataforma Google Forms no período de 22 de julho de 2020 a 23 de outubro de 2020 para 360 participantes e no período de 14 de janeiro de 2021 a 20 de maio de 2021 para 100 participantes. Os resultados demonstraram um nível médio de hesitação à vacina nas duas amostras. Foi encontrado um alto nível de percepção à vulnerabilidade à doença. Mais da metade dos participantes relaram intenção em se vacinar contra a COVID-19, no entanto uma parte significativa da amostra demonstrou que a origem da vacina poderia influenciar na decisão em se vacinar. Neste contexto, fatores como medo, percepção à doença infecciosa e ao cenário social, capacidade de pensamento crítico e confiança em órgãos especializados podem indicar a intenção de se vacinar ou não de uma população.

Palavras-chave: Comportamento de saúde; Percepção à vulnerabilidade à doença;

Covid-19; Hesitação à Vacina. 


\begin{abstract}
Oliveira, M.R.A. (2021). Cognitive-behavioral factors in vaccine hesitancy and disease perception: implications for the control of the COVID-19 pandemic. Dissertação de Mestrado, Programa de Pós-Graduação em Psicobiologia da Faculdade de Filosofia Ciências e Letras de Ribeirão Preto, Universidade de São Paulo.
\end{abstract}

Vaccine hesitancy is considered a worldwide public health problem by the World Health Organization that permeates behavioral and cognitive factors, such as perception of vulnerability to disease, critical thinking ability. It is a problem in Brazil, as the national vaccine coverage has been showing a significative reduction over the past 5 years. The new coronavirus pandemic has already led to death more than 600,000 Brazilians and the only existing treatment is the vaccine. The aim of this study was to evaluate and characterize the relationship between cognitive and behavioral factors that permeate perceptions and attitudes towards the COVID-19 vaccine in a sample of the Brazilian population at two different moments through the coronavirus pandemic. To achieve the aim of this study 10 questionnaires were used to measure and assess the intrinsic factors of vaccine hesitancy. The data collection took place through the Google Forms platform from 22 July 2020 to 23 October 2020 for 360 participants and from 14 January 2021 to 20 May 2021 for 100 participants. The results demonstrated an average level of vaccine hesitancy in the two samples. A high level of perception of vulnerability to the disease was also found. More than half of the participants reported an intention to be vaccinated against COVID-19, however a significant part of the sample demonstrated that the origin of the vaccine could influence the decision to be vaccinated. In this context, factors such as fear, perception of the infectious disease and the social scenario, critical thinking ability and trust in specialized agencies can indicate the intention of a population to get the vaccine or not.

Key words: Health behavior; Perception to disease vulnerability; Covid-19; Vaccine hesitancy. 


\section{LISTA DE ILUSTRAÇÕES}

Figura 1.

Continuum de aceitação à vacina.

Figura 2.

Modelo de Hesitação à Vacina - Modelo dos 3 Cs.

Gráfico 1.

Gráfico de dispersão da Correlação de Perason entre a Escala de Aderência às Teorias Conspiratórias (y) e a Escala de Atitudes Antivacina (x) com $\mathrm{p}<0.01$.

Gráfico 2.

Gráfico de dispersão da Correlação de Pearson entre a Escala de Hesitação à Vacina (y) e a Escala de Percepção à Vulnerabilidade à Doença Infecciosa $(\mathrm{x})$ com $\mathrm{p}<0.01$.

Gráfico 3.

Gráfico de Escarpa da Análise Fatorial Exploratória da Escala de AutoRelato de Credulidade.

Gráfico 4.

Gráfico de Escarpa da Análise Fatorial Exploratória da Escala de Percepção à Vulnerabilidade à Doença Infecciosa. 
Gráfico 5.

Gráfico de Escarpa da Análise Fatorial Exploratória da Escala de Aderência às Teorias Conspiratórias Antivacina.

Gráfico 6.

Gráfico de Escarpa da Análise Fatorial Exploratória da Escala de Atitudes Antivacina.

Gráfico 7.

Gráfico de Escarpa da Análise Fatorial Exploratória da Escala de Hesitação à Vacina.

Gráfico 8.

Gráfico de Escarpa da Análise Fatorial Exploratória da Escala de Inteligência Social.

Gráfico 9.

Gráfico de Escarpa da Análise Fatorial Exploratória da Escala de Vulnerabilidade Social. 


\section{LISTA DE TABELAS}

Tabela 1 - Caracterização da amostra da Fase $1(n=360)$.

Tabela 2 - Caracterização da amostra da Fase $2(n=100)$.

Tabela 3 - Frequência absoluta e porcentagem do questionário sociodemográfico dos respondentes do Módulo 7 sobre vacinação e infecção pela COVID-19 (n = 201).

Tabela 4 - Frequência absoluta e porcentagem do questionário sociodemográfico dos respondentes do Módulo 8 sobre vacinação e infecção pela COVID-19 ( $\mathrm{n}=159)$.

Tabela 5 - Frequência absoluta e porcentagem do questionário sociodemográfico dos respondentes da Fase 2 sobre vacinação e infecção pela COVID-19 (n = 100).

Tabela 6 - Frequência de gênero e análise estatística das escalas INP-16, Credulidade, Percepção à Vulnerabilidade à Doença; Aderência às Teorias Conspiratórias, e Atitudes Antivacina dos respondentes do Módulo 7 (n=201).

Tabela 7 - Frequência de gênero e análise estatística das escalas VHS, Escala de Inteligência Autoavaliada, Escala de Percepção à Vulnerabilidade à Doença Infecciosa, Escala de Inteligência Social e Escala de Vulnerabilidade Social dos respondentes do Módulo 8 ( $\mathrm{n}=159)$.

Tabela 8 - Frequência de gênero e análise estatística das escalas VHS, Percepção à Vulnerabilidade à Doença; Aderência às Teorias Conspiratórias; e Atitudes Antivacina $(n=100)$.

Tabela 9 - Análise de Correlação de Pearson entre as escalas de Aderência às Teorias Conspiratórias e de Atitudes Antivacina com $\mathrm{p}<0.01$.

Tabela 10 - Análise de Correlação de Pearson entre INP-16 e a Escala de Aderência às Teorias Conspiratórias com $\mathrm{p}<0.01$.

Tabela 11 - Análise de Correlação de Pearson entre INP-16 e a Escala de Atitudes Antivacina com $\mathrm{p}<0.01$ 
Tabela 12 - Análise de Correlação de Pearson entre as VHS e a Escala de Percepção à Vulnerabilidade à Doença Infecciosa com $\mathrm{p}<0.01$.

Tabela 13 - Estudo de validade da Escala de Auto-Relato de Credulidade a partir do critério Kaiser.

Tabela 14 - Matriz de Componente rotativa da Escala de Auto-Relato de Credulidade.

Tabela 15 - Estudo de validade da Escala de Percepção à Vulnerabilidade à Doença Infecciosa a partir do critério Kaiser.

Tabela 16 - Matriz de componente rotativa da Escala de Percepção à Vulnerabilidade à Doença Infecciosa.

Tabela 17 - Estudo de validade da VCBS a partir do critério Kaiser.

Tabela 18 - Matriz de componente rotativa da VCBS.

Tabela 19 - Estudo de validade da Escala de Atitudes Antivacinação a partir do critério Kaiser.

Tabela 20 - Matriz de Componente rotativa da Escala de Atitudes Antivacina.

Tabela 21 - Estudo de validade da Escala de Hesitação à Vacina a partir do critério Kaiser.

Tabela 22 - Matriz de componente rotativa da Escala de Hesitação à Vacina.

Tabela 23 - Estudo de validade da Escala de Inteligência Social a partir do critério Kaiser.

Tabela 24 - Matriz de Componente Rotativa da Escala de Inteligência Social.

Tabela 25 - Estudo de validade da Escala de Vulnerabilidade Social a partir do critério Kaiser.

Tabela 26 - Matriz de Componente rotativa da Escala de Vulnerabilidade Social. 


\section{SUMÁRIO}

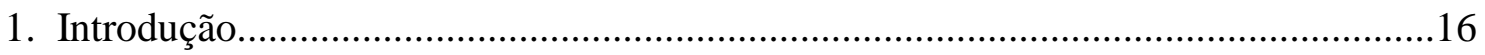

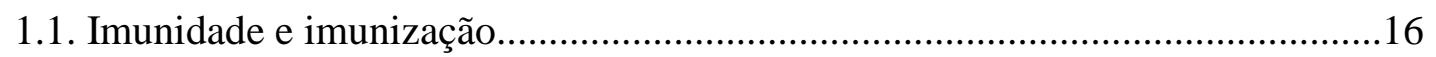

1.1.1. Doenças infecciosas e o papel da vacinação na saúde pública..................16

1.1.2. Hesitação e recusa vacinal: Confiança, complacência e conveniência.....17

1.2. Pandemia do novo Corona vírus - COVID-19 e a corrida das vacinas.............21

1.3. Fatores cognitivos e comportamentais presentes na hesitação a vacina na

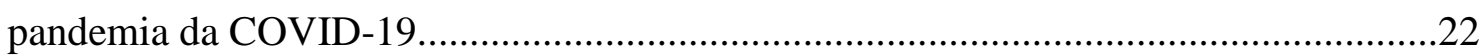

1.3.1. Fatores cognitivos, comportamentais e personalidade............................22

1.3.2. Percepção à doença infecciosa............................................................25

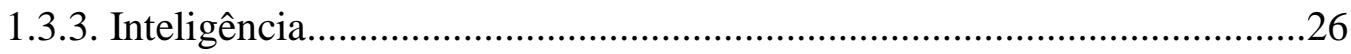

1.3.4. Mídias sociais e o pensamentos anti-ciência.............................................27

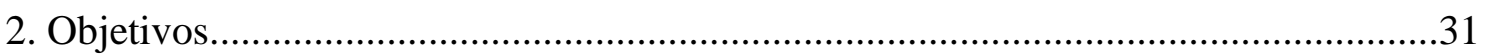

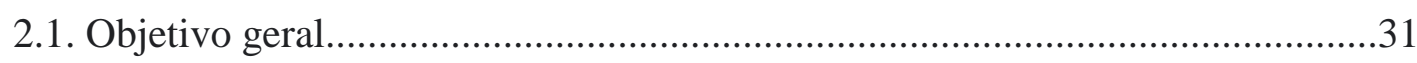

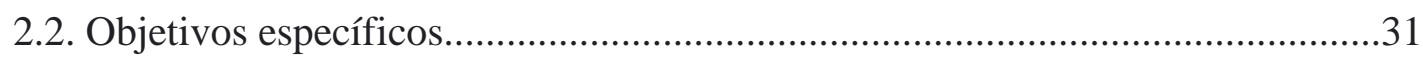

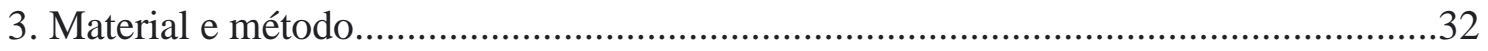

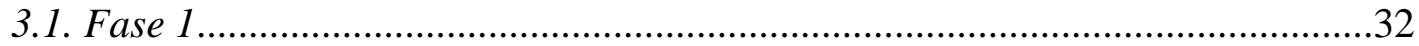

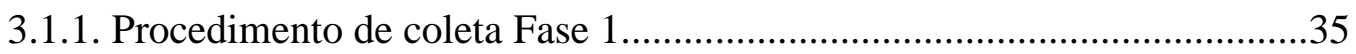

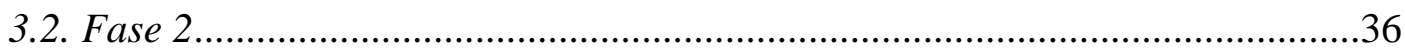

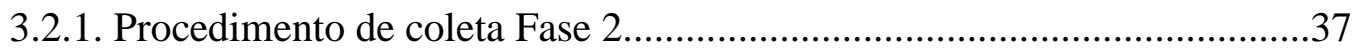

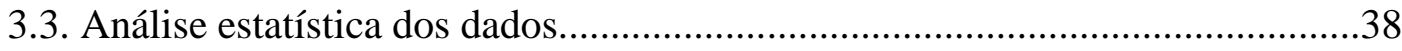

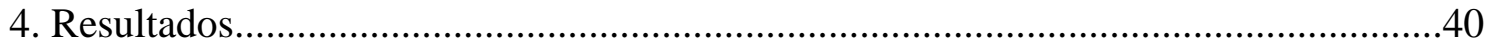

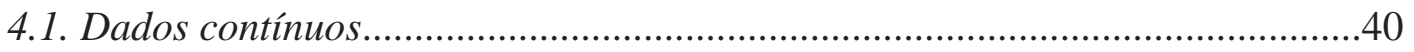

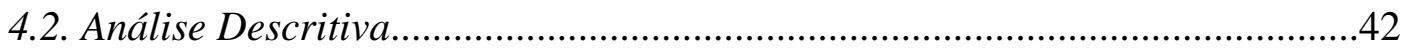

4.2.1 Escores e frequências estatísticas........................................................42

4.2.2. Correlação de Pearson............................................................................44 
4.3. Análise fatorial exploratória. 48

5. Discussão .62

5.1. Fatores cognitivos, comportamentais e personalidade nas atitudes antivacina.65

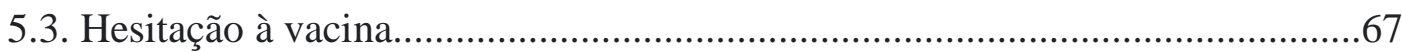

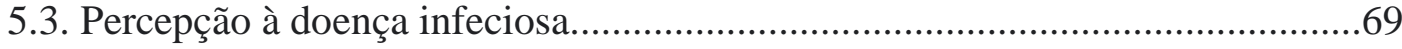

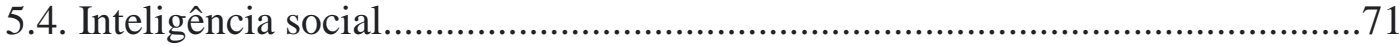

5.5. O lugar do Brasil na pandemia da covid-19................................................72

5.6. Análise Fatorial Exploratória e Correlações entre fatores..................................73

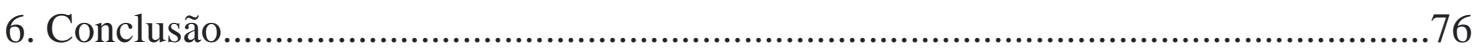

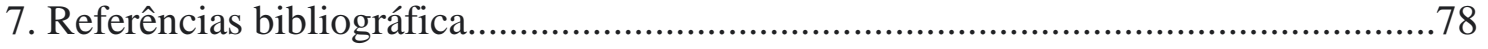




\section{Introdução}

\subsection{Imunidade e imunização}

\subsubsection{Doenças infecciosas e o papel da vacinação na saúde pública}

Vacina é uma substância que é dada à uma pessoa - ou animal - para protegê-la de um patógeno - bactéria, vírus ou outro microorganismo que possa causar alguma doença infecciosa (Feemster, 2018). Segundo a Organização Mundial da Saúde (OMS) (World Health Organization - WHO), a vacinação previne de dois a três milhões de óbitos no mundo todo (WHO, 2013) e é uma ferramenta de saúde pública, uma vez que a decisão de se vacinar ou não tem impacto individual e coletivo (Xiao \& Wong, 2020; WHO, 2013).

Segundo dados da Organização Mundial da Saúde, a vacinação salva anualmente entre 2 e 3 milhões de vidas todos os anos no mundo todo (WHO, 2017). De forma simplificada, a vacina irá possibilitar que grupos de pessoas que não tenham em seu organismo a capacidade de combater alguma doença infecciosa (geralmente crianças e mulheres grávidas) sejam protegidos de maneira indireta (Dubé et al, 2015). Ou seja, a vacina irá reduzir o número de indivíduos suscetíveis à doença fazendo parar, assim, a transmissão entre pessoas (Feemster, 2018). É o que chamamos de imunidade de rebanho. Há também a imunidade natural, que é adquirida ao contrair a doença infecciosa.

No entanto, estes dois tipos de imunidade podem falhar. A primeira, pois a partir do momento em que um número significativo de indivíduos não se vacina - ou deixa de tomar a dose anual de alguma vacina que deve ser sazonalmente reforçada pode ocorrer um surto de determinada doença - e não há nada a se fazer que pararia a transmissão (Taylor, 2019; Feemster, 2018). A segunda, que é a imunidade natural, é a mais arriscada, pois para adquiri-la envolve o risco de o indivíduo ficar gravemente doente ou até vir a morrer em decorrência da doença (Feemster, 2018).

Historicamente, a primeira vacina surgiu em 1796 com a descoberta da vacina contra a Varíola pelo médico inglês Edward Jenner (Órtiz-Sanchez et al., 2020; Dubé et al., 2015). Assim, a partir de 1800 a população da Europa foi vacinada contra varíola de maneira obrigatória e compulsória, o que levou a população a criar a "Liga Contra Vacinação Obrigatória”, em 1867 (Órtiz-Sanchez et al., 2020; Dubé et al., 2015). 
No Brasil, as primeiras campanhas de vacinação datam do ano de 1804 e tinham o mesmo caráter obrigatório das campanhas inglesas, e objetivavam prevenir a febre amarela, varíola e poliomielite (Beltrão et al., 2020). Diante da obrigatoriedade e da vacinação compulsória, a população criou um sentimento negativista que sustentava as crenças de que as vacinas não eram seguras ou eram armas biológicas utilizadas pelo governo para o controle populacional (Beltrão et al., 2020).

Em 1904, no Brasil, ocorre a Revolta da Vacina, que foi uma manifestação popular da população do Rio de Janeiro contra as ações governamentais que tornavam a vacinação obrigatória e puniam quem se recusasse a tomar (Dubé et al., 2015). Por ser essencial para a imunização das pessoas e erradicação das doenças, programas governamentais foram criados para facilitar o acesso e incentivar a população a se vacinar. Em 1973 o Ministério da Saúde elaborou o Programa Nacional de Imunizações (PNI) que passou a coordenar as ações de promoção à saúde pela rede pública de saúde, diferente das antigas campanhas de caráter obrigatório e punitivo (Ministério da Saúde, 2013).

Com uma campanha de vacinação mais acessível e menos assertiva, o Brasil se tornou referência mundial, sendo pioneiro na disponibilização de vacinas de modo universal (Beltrão et al., 2020). Até 2012 o Brasil mantinha uma cobertura vacinal de Sarampo de 99\%. Desde 2014 essa porcentagem vem caindo de modo alarmante, juntamente com novos casos da doença (Beltrão et al., 2020; Almeida et al., 2020). Dados mais atuais do Ministério da Saúde (Ministério da Saúde, 2019), no ano de 2019, retratam que foram confirmados 5.346 casos de sarampo com uma cobertura vacinal de $52,78 \%$.

A eficácia das vacinas contra doenças transmissíveis é considerada como um dos fatores responsáveis pela hesitação à mesma. Isso está ligado à crença de que pelo fato da doença ter baixíssima incidência não é necessário vacinar seus filhos (Órtiz-Sanchez et al., 2020). A vacina acaba sendo vítima de sua própria eficácia, pois, uma vez que determinada doença foi erradicada a percepção da população é que não há mais necessidade de se prevenir.

\subsubsection{Hesitação e recusa vacinal: Confiança, complacência e conveniência}

A hesitação vacinal se refere à demora na aceitação ou à total recusa de uma vacina, independente de sua disponibilidade nos serviços de saúde locais (WHO, 2014). 
Esta definição foi estabelecida pelo Strategic Dvisory Group of Experts on Immunization (SAGE) Working Group on Vaccine Hesitancy, cirado em 2012 pela OMS, que caracterizou os fatores que podem influenciar na decisão de aceitar ou recusar as vacinas, tendo em vista a tendência mundial crescente deste fenômeno (Succi, 2017; WHO, 2014).

O SAGE Working Group on Vaccine Hesitancy busca avaliar os fatores de influência na confiança nas vacinas para, assim, desenvolver intervenções que possam corrigir falhas na comunicação e evitar surtos de doenças que podem ser totalmente prevenidas com vacinas (MacDonald, 2015; Salmon et al., 2015). Em 2012 a OMS definiu as atitudes relacionadas à vacinação em um continuum que vai desde a aceitação total até a uma recusa total de vacinas que, respectivamente, estariam relacionadas com a alta e a baixa demanda para determinada doença prevenida por vacinação - a hesitação se encontraria em um espaço entre estas duas atitudes (WHO, 2014).

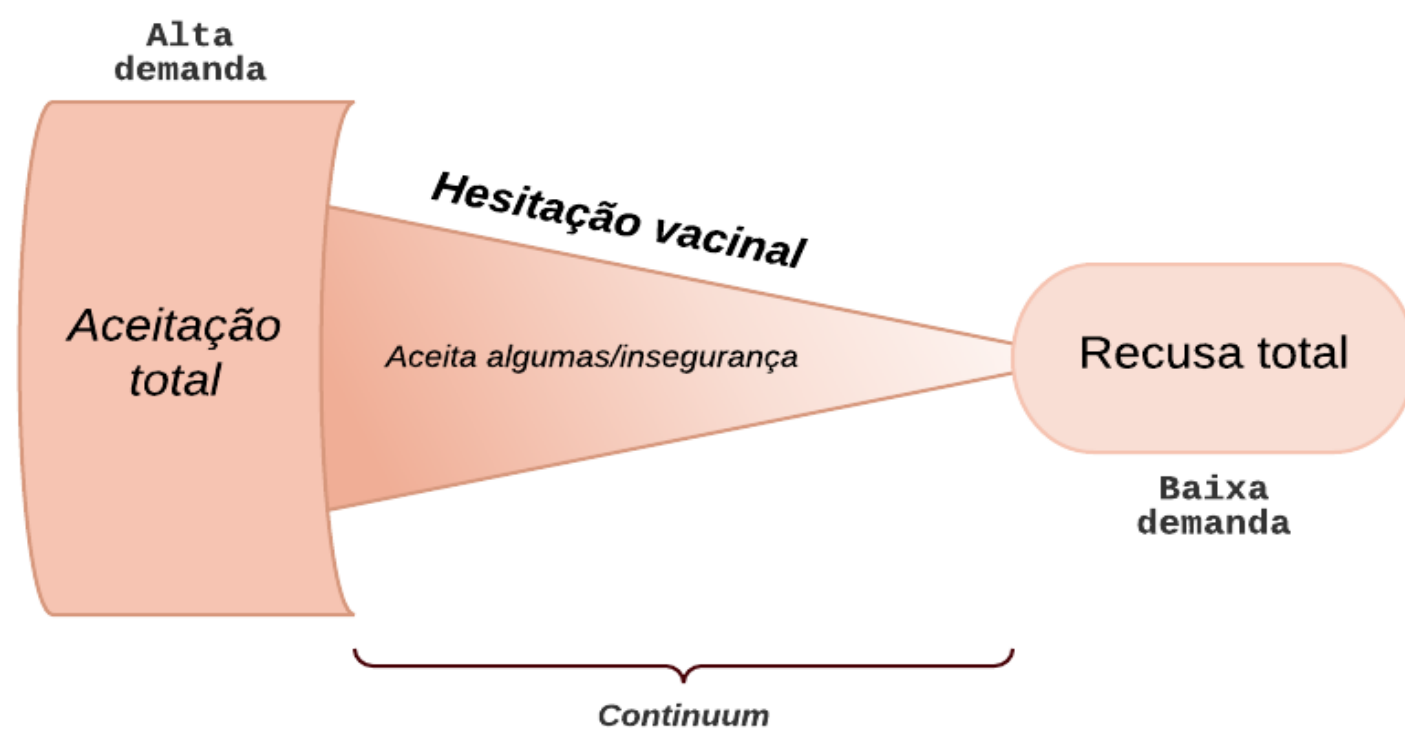

Figura 1. Continuum de aceitação de vacina (adaptado de WHO, 2013).

A hesitação vacinal é entendida, portanto, como um comportamento que resultará no processo de tomada de decisão e reflete a interação de fatores que podem influenciar nesta decisão dentro do continuum (Larson et al., 2018; WHO, 2014).

Segundo a OMS, os fatores estudados e listados como significativamente influentes na hesitação foram considerados pela sua aplicabilidade a nível global (WHO, 2014). A importância de ser um modelo passível de avaliação e até mensuração de seus fatores por meio questionários e outros instrumentos (WHO, 2014) se dá pela 
possibilidade de intervenção no processo de tomada de decisão da hesitação vacinal, já que este é um comportamento que pode ser modificado para a aceitação (Larson et al., 2014).

O Modelo da Hesitação à Vacina - ou "Modelo dos 3 Cs" (Figura 2) - é definido em: Confiança na efetividade e segurança das vacinas, dos sistemas e profissionais de saúde que a oferecem e das motivações políticas que decidem a necessidade da vacina; Complacência, na qual a percepção dos riscos de uma doença infecciosa é baixa, dando a entender que a vacina não é uma ação preventiva necessária; e Conveniência, que é medida pela disponibilidade, acessibilidade e entrega das vacinas em um contexto favorável (WHO, 2014).

Baseando-se no Modelo dos 3 Cs, a OMS entende que, dentro destes grandes fatores estão envolvidas também questões mais específicas a nível contextual com fatores mais amplos que podem ser considerados como fatores potenciais na tomada de decisão (Larson et al., 2014). São considerados três domínios-chaves: 1- Influências Contextuais; 2- Influências individuais e coletivas; 3 - Questões relativas às vacinas e à vacinação (Larson et al., 2014; WHO, 2014).

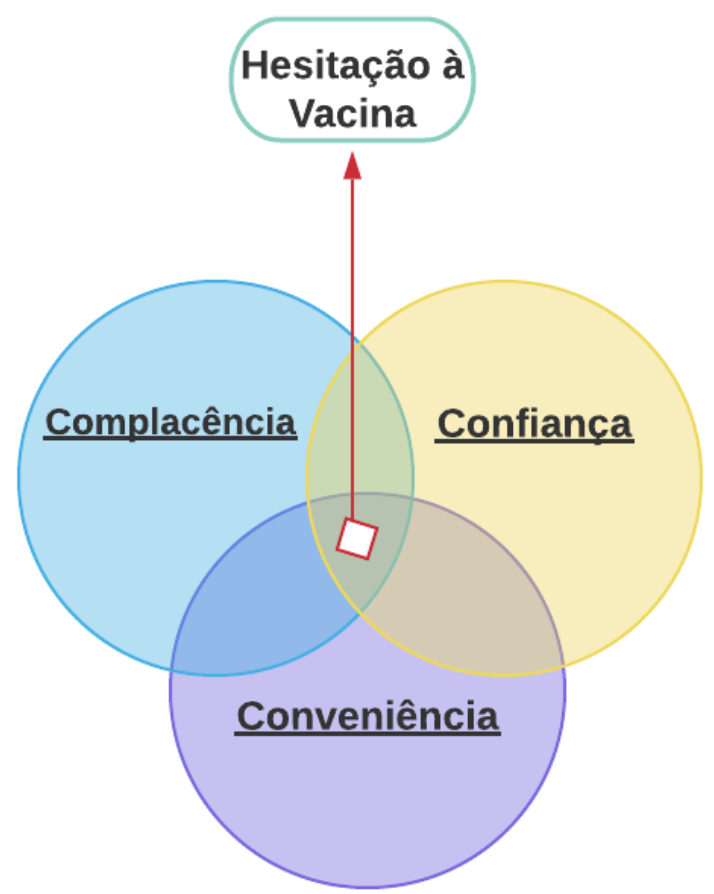

Figura 2. Modelo dos 3 Cs (adaptado de WHO, 2014).

Entender as motivações e crenças sobre a saúde pode contribuir na decisão de se vacinar (Cerda \& García, 2021). A decisão de se vacinar ou não ocorre em um contexto de confiança nos diversos fatores envolvidos neste processo (programas de imunização 
locais, percepção de risco à doença e até o envolvimento de personalidades políticas) (Larson et al., 2018). Estes indivíduos considerados hesitantes podem aceitar algumas vacinas, mas recusar outras.

Estudos têm indicado que os principais fatores envolvidos nesta decisão são medo de efeitos adversos, consideração de opiniões de familiares ou médicos contrários à vacinação, crenças religiosas, nível socioeconômico e educacional, comunicação da mídia sobre determinada doença e vacinas ou até mesmo posicionamento político (Camargo et al., 2020; Taylor, 2020; Cerda \& García, 2021; Larson et al., 2014).

Desde 2019 a OMS considera a hesitação vacinal como uma das dez ameaças para a saúde global (WHO, 2020). É um fenômeno que já afeta 90\% dos países e se espalha de forma rápida e fácil por grupos e afinidades ideológicas, afetivas e comportamentais (Petousis-Harris et al., 2020; Ward, 2016). No entanto não é um movimento tão recente, visto que revoltas ou agitações populares e desconfiança contra as vacinas ocorrem desde o século XIX devido ao desconhecimento dos riscos da doença, da importância da imunidade pela vacinação e de medidas governamentais coercitivas e punitivas para se alcançar um bom índice vacinal (Beltrão et al., 2020; Órtiz-Sanchez et al., 2020; Dubé et al., 2015).

Dentro do continuum da hesitação vacinal há o movimento antivacina, ambos podem ocorrer pela propagação de informações erradas, distorcidas ou extrapoladas sobre os efeitos adversos das vacinas (Camargo et al., 2020). Um dos momentos mais relevantes e que colaborou para fortalecer a hesitação vacinal nos séculos XX e XXI foi a publicação de um artigo fraudulento em 1998 quando o médico Andrew Wakefield publicou na revista científica Lancet um artigo que afirmava que a vacina contra sarampo, caxumba e rubéola tinha relação com o desenvolvimento de autismo (Wakefield, 1998).

Países como os Estados Unidos da América e França são reconhecidos pelos altos índices de hesitação vacinal atualmente - por exemplo, em relação à epidemia da vacina contra a Influenza H1N1 (Ward, 2016; Larson et al., 2014). Mesmo sendo mundialmente reconhecido pelos altos índices de cobertura vacinal e pelo sucesso das campanhas públicas de vacinação (Almeida et al., 2020; Brasil, 2013), o Brasil tem sido afetado negativamente por esse movimento.

Foi observada uma redução significativa na cobertura vacinal de quase todas as vacinas disponibilizadas pelo Sistema Único de Saúde (SUS) nos últimos cinco anos (Almeida et al., 2020; Beltrão et al., 2020). Entre as vacinas que registraram as maiores 
reduções estão: DTP 4 a 6 anos (63,5\%), Poliomielite 4 anos (69\%) e a Tetra (71\%), coincidindo com a faixa etária entre 0-6 anos, alvo principal do movimento antivacina (Bernardo, 2019).

\subsection{Pandemia do novo Corona vírus - COVID-19 e a corrida das vacinas}

Em dezembro de 2019 a China teve seus primeiros casos de COVID-19 (WHO, 2020c). A nova doença (COVID-19) é causada pela síndrome respiratória aguda grave coronavírus-2 (SARS-CoV-2). No dia 11 de março de 2020 a OMS declarou a pandemia do novo coronavírus - COVID-19 com um comunicado oficial indicando que, até aquele momento 118,000 casos reportados em pelo menos 114 países pelo mundo (WHO, 2020a).

A OMS neste comunicado orientou os líderes de cada país que estava sendo afetado pela COVID-19 a prepararem os sistemas de saúde, monitorar o surgimento de novos casos e a adotarem medidas coletivas e individuais de prevenção (WHO, 2020c). Juntamente com a falta de um tratamento efetivo contra esta nova doença, a adoção de medidas comportamentais preventivas para tentar diminuir a infecção e a transmissão por exemplo, uso de máscaras, higiene das mãos e superfícies, distanciamento social e até isolamento social - foi essencial (Taylor, 2019; WHO, 2020c).

Essas medidas preventivas, além de objetivarem a proteção individual, serviram para desacelerar a transmissão do vírus, diminuir a mortalidade e não sobrecarregar os profissionais e sistemas de saúde (Murphy et al., 2021; WHO, 2020c). Notícias falsas, suposições e teorias conspiratórias foram criadas acerca do novo coronavírus e sua origem, fator que pode ter contribuído para hesitação à vacina contra a COVID-19 e a não adoção efetiva das medidas preventivas (Pummerer et al., 2021).

Desde o anúncio da OMS declarando a COVID-19 como uma pandemia (WHO, 2020), cientistas de universidades do mundo todo começaram a trabalhar em busca de uma vacina. O primeiro teste clínico em seres humanos de uma possível vacina contra a covid-19 foi feito em 3 de março de 2020 nos EUA (National Institute of Health, 2020).

Desde o início do segundo semestre de 2020 tem sido noticiado que a vacina contra a Covid-19 poderia ser aprovada entre outubro e dezembro. Desde o início de dezembro de 2020, com a aprovação das vacinas, alguns países como Argentina, Estados Unidos da América e Inglaterra iniciaram a vacinação nos grupos de risco e em profissionais de saúde que estão na linha de frente. 
Enquanto isso, mais de um mês depois de vários países iniciarem suas campanhas de vacinação, o estado de São Paulo deu início à vacinação do estado no dia 17 de janeiro de 2021, e a vacinação a nível nacional teve início no dia 19 de janeiro de 2021. As vacinas disponíveis no Brasil para uso emergencial, aprovadas pela Agência Nacional de Vigilância Sanitária, são a Coronavac, do Instituto Butantan (ANVISA, 2021a), e a AstraZeneca, da Fiocruz (ANVISA, 2021b). No entanto, sem possuir um Plano de Vacinação concreto e com a possibilidade de faltar insumos para tal, o Brasil vive uma luta política em relação a vacina desde agosto de 2020.

Em 2020, a disseminação de informações falsas sobre vacinas aumentou significativamente (Beltrão et al., 2020). Movimentos negacionistas, que são contra a ciência e órgãos de saúde, em relação a pandemia da COVID-19 também têm ganhado cada vez mais espaço nas redes sociais e adeptos ao redor do mundo.

A OMS define como "infodemia" uma quantidade excessiva de informações inseguras sobre um determinado problema, associadas às buscas reativas em tempos de grandes medos, o que pode dificultar os caminhos para soluções ao criar tumultos e desconfiança entre leigos (WHO, 2019). As compreensões científicas do cenário pandêmico da COVID-19 sofrem mudanças diárias, gerando medo, incertezas e até desconfiança na população (Vasconcellos-Silva et al., 2020).

No Brasil estudos sobre os fatores que influenciam em atitudes e comportamentos antivacina ainda são escassos, pois apesar da recente queda vacinal dos últimos 5 anos, o país não abraçava o movimento com tanta força. No entanto, o cenário atual da pandemia da COVID-19 trouxe muitas incertezas e descrença da população aos órgãos de saúde e desconfiança em relação à ciência.

Até o momento da finalização deste estudo - Agosto de 2021 -, a pandemia da COVID-19 já matou mais de 4 milhões de pessoas pelo mundo, somando um total de 219 milhões de casos (Ritchie et al., 2021).

\subsection{Fatores cognitivos e comportamentais presentes na hesitação a vacina na pandemia da COVID-19}

\subsubsection{Fatores cognitivos, comportamentais e personalidade}

Atitudes e comportamentos antivacinação estão em crescimento desde o início da pandemia em países que não possuíam problemas nas campanhas de vacinação, 
como o Brasil (Beltrão et al., 2020). Visões equivocadas sobre vacinas e a hesitação à vacina são problemas presentes em países como Estados Unidos da América e França desde epidemias como a da H1N1 (Pummerer et al., 2021).

Diversos estudos têm buscado explicar o fenômeno da hesitação à vacina por teorias comportamentais como a Teoria do Comportamento Planejado (TPB) e o Modelo de Crença À Saúde (HBM) (Fishbein et al., 2006; Fishbein et al., 2010). Estes modelos sugerem que os indivíduos são mais suscetíveis a se comportarem para controlar a transmissão de uma doença se a perceberem como letal ou se perceberem a si próprios como suscetíveis à contaminação (Park et al., 2020; Xiao \& Wong, 2020).

Traços de personalidade têm sido relacionados à probabilidade do individuo experienciar emoções negativas em resposta a eventos estressores (Taylor, 2019). Pessoas com pontuações altas em instrumentos que avaliam estes traços tendem a manifestar emoções negativas - como ansiedade e depressão - quando expostas a eventos estressores (Sternberg, 2000). Além disso, estudos sugerem que há uma tendência da crença em teorias conspiratórias - ou informações falsas - ser caracterizada por motivos epistêmicos, existenciais e sociais (Taylor 2019; Douglas et al., 2017).

Os adeptos a movimentos que questionam ou negam vacinas e a própria ciência têm sido caracterizados em estudos como grupos de pessoas que são pessoas mal preparadas para compreender os aspectos da epidemiologia, imunologia, etc., com um padrão cognitivo limitado para o pensamento crítico, o que pode fazer com que se sintam mais certezas sobre as próprias crenças (Oliveira \& Da Silva, 2021; Camargo Jr, 2020). Estas características podem indicar traços de personalidade narcisista a partir do momento em que estas pessoas acreditam ser mais inteligentes e possuírem mais conhecimento do que especialistas, pois estão providas de informação secreta que é ocultada das massas (Taylor, 2019; Park et al., 2020).

Assim, diversos estudos (Douglas et al., 2017, 2019; Galliford \& Furnham, 2017; Lantian et al., 2017) sugerem que esta tendência a adesão a teorias conspiratórias, falsas informações e atitudes antivacina e anticiencia estão correlacionadas com traços narcisistas (necessidade de se sentir único, que pode ser cumprida ao achar que se tem posse de informações privilegiadas) e a um nível de ingenuidade (credulidade, acesso baixo à literatura e informações verdadeiras, bem como baixa capacidade de pensamento crítico para analisar as fontes e conteúdo de determinada informação (Taylor, 2019). 
Todas as incertezas que permeiam a pandemia da COVID-19 - duração da pandemia, medidas de prevenção, estudos iniciais para uma vacina para uma doença ainda desconhecida - pode levar a população a criarem teorias conspiratórias que preencham essas incertezas (Taylor, 2019). Essas teorias irão se ater a informações que confirmem crenças pessoais e que vão "desmentir" órgãos superiores e especialistas: se a curva diminuiu, não eram necessárias todas as medidas preventivas impostas e mudanças de atitudes da população (apesar de terem sido esses fatores que obtiveram esse resultado) (Oliveira \& Da Silva, 2021; Biddlestone et al., 2020).

Outro fenômeno que vem recentemente ganhando destaque nas explicações de teorias negacionistas é o Dunning Kruger Effect (DKE) (Oliveira \& Da Silva, 2021). O DKE define-se por pessoas que dizem ter informações sobre determinado assunto, desacreditando das informações de especialistas e acreditando que são superiores (Muller et al., 2021). Para Muller et al. (2021), o que ocorre no DKE é uma superioridade ilusória que pode ser motivada, em parte, pela familiaridade de alguma situação por experiências anteriores.

No caso do movimento antivacina, as pessoas tendem a alegar que "determinado pesquisador" afirmou que não há evidencias de que vacinação seja benéfica para o ser humano, ou que alguma "personalidade importante" afirmou que "nunca viu nenhum caso grave de determinada doença". Essas personalidades utilizadas para justificar alguma informação falsa geralmente não existem ou não possuem formação para falar sobre o assunto, mas acabam passando mais credibilidade por causa dos seus títulos (Weitz et al., 2020).

A recusa do conhecimento científico, segundo Camargo Jr (2020) é reforçada por fenômenos sociocognitivos complexos, como o backfire effect, ou seja, uma vez que uma pessoa tenha acreditado em uma concepção errada, a apresentação de fatos e evidências científicas não irão enfraquecer tal, irá apenas fortalecê-la. (Camargo Jr., 2020). É o que vem ocorrendo em parte da população desde março com o início da pandemia da COVID-19. Quanto mais informações falsas sobre a doença e seus possíveis tratamentos surgiam na mídia, mais os cientistas e pessoas bem instruídas tentam expor as informações verdadeiras, o que só serve de reforço para as fake News (Oliveira \& Da Silva, 2021).

Há também a tendência da hesitação ou negação à vacina estar relacionada com pensamentos mágicos, narcisismo, preocupação com a saúde e mortalidade dos outros, ingenuidade e aceitação de pseudociências em detrimento de comprovações científicas. 
No geral, sugere-se que as teorias conspiratórias atraem pessoas que buscam significados para questões pessoais ou não possuem capacidade cognitiva para encontrar as respostas de maneira racional, o que pode levar à crença de que possuem informações raras que outras pessoas não têm (Camargo Jr, 2020; Taylor, 2019).

\subsubsection{Percepção à doença infecciosa}

O modelo de percepção de risco descreve as reações do indivíduo ao perigo como instintiva ou intuitiva (Slovic et al., 2004). Os riscos de determinada situação são percebidos como mais perigosos quando são incomuns, desconhecidos pela ciência, caracterizados por uma catástrofe natural ou leva várias pessoas a morte em pouco tempo (Caserotti et al., 2021).

Um dos principais papeis da percepção ao risco é feito por questões afetivas: a percepção irá demarcar o estímulo ou contexto como positivo ou negativo (Slovic et al., 2004). Assim, a heurística do afeto indica que as pessoas irão considerar um risco de um evento não apenas com base em informações objetivas, mas também com base nos sentimentos vivenciados (Caserotti et al., 2021).

Considerando a percepção de risco em casos de epidemias ou pandemias, as dimensões afetivas encontradas permeiam o medo, preocupação e ansiedade (Taylor, 2019; karlsson et al., 2020). A gripe comum, por exemplo, comumente induz uma percepção de baixo risco, uma vez que as pessoas estão familiarizadas e, provavelmente, já se contraíram a gripe em algum momento, além de ser uma doença que não possui um curso letal, logo não evocará componentes afetivos intensos (Caserotti et al., 2021).

Segundo Taylor (2019), os indivíduos que apresentarem níveis médios a altos de percepção a eventos ainda desconhecidos, podem experienciar comportamentos preventivos repetitivos e excessivos e um medo constante de infecção, independente dos dados estatísticos sobre a real severidade da situação. Durante um contexto pandêmico, em um primeiro momento a percepção de risco seria extremamente elevada, gerando medo, comportamentos preventivos em excessos, ansiedade de se infectar, percepção distorcida da própria saúde (considerando que possa estar infectado mesmo sem ter sido exposto ao risco), depressão e afetos negativos devido à perda de familiares, conhecidos e por perdas financeiras (Jetten et al., 2020; Passos et al, 2020; Taylor, 2019). 
Com a percepção de risco elevada a busca e aceitação por medidas preventivas e possíveis vacinas ou medicamentos tem uma tendência maior a serem aceitos, pois a dimensão emocional da percepção de risco guia a tomada de decisão para a busca e aceitação de ações preventivas (Chapman \& Coups, 2006). Assim, quanto maior a percepção de risco, maior a intenção de se vacinar e menor a tendência de passar pelo processo da hesitação vacinal (Caserotti et al., 2021; Ibuka et al., 2010).

Conforme o contexto pandêmico se estende por um determinado período de tempo, a tendência é que ocorra uma habituação em relação aos comportamentos, afetos e percepção (Taylor, 2019; Ajzen, 2002b). Com a exposição ao estímulo aversivo, a percepção ao risco diminui, logo comportamentos e atitudes preventivas são flexibilizadas, uma vez que os fatores afetivos não estão em um nível negativo intenso como antes e os fatores ambientais já são percebidos como estímulos neutros ou sem um impacto tão forte (Caserotti et al., 2021; Slovic et al., 2004).

A contaminação por uma doença infecciosa sem maiores complicações para à saúde pode diminuir a percepção ao risco também (Taylor, 2019). Assim, estudos têm evidenciado que quanto menor o nível de percepção ao risco, menor a intenção de se vacinar, possibilitando o processo de hesitação ou negação à vacina (Caserotti et al., 2021; Ibuka et al., 2010).

\subsubsection{Inteligência}

A definição geral de inteligência é a capacidade geral da mente que permite o raciocínio, o planejamento, a resolução de problemas, pensamento abstrato, a compreensão de ideias complexas e a aprendizagem (Da Silva, 2003). Há uma variedade de teorias sobre inteligência que trazem diferentes perspectivas, bem como a ideia da existência de inteligências múltiplas (Sternberg, 2000).

Um dos conceitos mais aceitos e utilizados para mensuração da inteligência é o da Inteligência Geral (ou Fator g). O modelo do Fator g trata a inteligência como um fator unidimensional, mas considerando dois fatores: fator geral da habilidade cognitiva (g) e outros fatores específicos que seriam subjacentes a g (Da Silva, 2003). Este modelo de inteligência corresponde à percepção de inteligência da maioria das pessoas (Carrol, 1997).

Outras definições consideram que inteligência e ambiente possuem interações diretas e indiretas. Considera-se que tanto o ambiente físico - alimentação, qualidade de 
vida e saúde física - e o ambiente social - escolaridade, vivências sociais, estimulação para desenvolvimento de habilidades cognitivas - podem afetar o nível de inteligência (Hunt, 2010). Estas influências ambientais na inteligência podem afetar também nos comportamentos sociais e na percepção ambiental de um indivíduo (Silvera et al., 2001).

A facilidade - ou dificuldade - de perceber padrões comportamentais e as consequências dos mesmos em outras pessoas é definida pelo conceito de inteligência social (Silvera et al., 2001). É um construto de difícil conceitualização e é multifacetado. Os autores Kosmitzki e John (1993) identificaram alguns componentes deste modelo: percepção dos eventos internos e humores de outras pessoas; habilidade de lidar com diferentes tipos de pessoas; conhecimento sobre regras sociais de convivência; boa sensibilidade e habilidade de resolução de problemas em situações complexas; e adaptação social (Silvera et al., 2001).

\subsubsection{Mídias sociais e o pensamentos anti-ciência}

Segundo Taylor (2019), teorias conspiratórias são mais prováveis de surgir durante períodos de incertezas em relação a grandes eventos, especialmente se esses eventos podem afetar pessoas importantes e famosas. Junto à pandemia da Covid-19 um fenômeno vem sendo cada vez mais comum, a "infodemia", que é descrita pela OMS como uma quantidade excessiva de informações inseguras sobre um determinado problema, em tempos de grandes medos, o que pode dificultar os caminhos para as soluções ao criar tumultos e desconfiança entre leigos (Vaconcellos-Silva \& Castiel, 2020).

Segundo os autores Ortiz-Sánchez et al. (2020), as pessoas que recusam as vacinas são mais prováveis de buscar informações sobre saúde nas redes sociais, e não com profissionais da área da saúde ou ciência. Além disso, a internet e as redes sociais se tornaram lugares de disseminação de teorias conspiratórias e mitos sobre vacinas e prevenção de doenças, sendo nesses meios de comunicação que os membros do grupo antivacina procuram informações que se adequem às suas crenças (Taylor, 2019).

Os algoritmos criados para aumentar os ganhos corporativos com a publicidade criam "bolhas" que impedem visões contestadoras de penetrar eficazmente em grupos conspiratórios, promovendo um ambiente de reforço positivo a todos os tipos de conceitos errados. Os especialistas acabam caindo no backfire-effect, citado 
anteriormente, pois tentam combater informações falsas (carregadas de fatores emocionais e pessoais) com as verdadeiras utilizando termos técnicos em demasia (Camargo Jr, 2020).

Atualmente o fácil e irrestrito acesso a todo tipo de informações, verdadeiras ou falsas, sobre aspectos de saúde pública e, principalmente, sobre as vacinas, têm tido grande influência na tomada de decisão sobre se vacinar ou não (Succi, 2018). Com a popularização da internet e das mídias sociais ao redor do mundo, ficou muito fácil e rápido buscar ou divulgar qualquer informação ou notícia. No entanto, nem sempre encontramos fontes confiáveis e para pessoas leigas ou ingênuas é difícil julgar a confiabilidade e a veracidade de determinada informação na internet. Em um estudo, Eysenbach et al. (2002) constataram que $70 \%$ dos websites que apresentam informações sobre cuidados e saúde possuíam problemas significativos em sua qualidade.

Em fevereiro de 2020 a OMS anunciou o nome oficial da SARS-CoV-2 como Covid-19 para evitar julgamentos enquanto a origem geográfica, étnica ou de alguma espécie animal do vírus (WHO, 2020a). No entanto, conforme a pandemia avançava, notícias falsas sobre a China - país que registrou o primeiro caso da doença - e consequências do vírus tomavam conta da internet, gerando uma onda de ataques xenofóbicos e preconceituosos. Quando os primeiros estudos sobre uma provável vacina começaram, no primeiro semestre de 2020, logo a mídia apelidou as prováveis vacinas com suas respectivas nacionalidades, denominando-as de "vacina da China", "vacina russa" ou "vacina de Oxford", dando margem para atitudes xenofóbicas (Gramacho \& Turgeon, 2021).

As pessoas que recusam vacinas são mais propensas a obter informações de redes sociais, não de profissionais de saúde ou sites de saúde verificados (Gramacho \& Turgeon, 2021; Ortiz-Sanchez et al., 2020). Para Beltrão et al. (2020), as redes sociais foram um fator de extrema relevância para a disseminação de teorias conspiratórias e do movimento antivacina. Segundo os autores, $43 \%$ dos usuários das mídias sociais afirmam fazer uso de duas horas diárias das redes, o que é uma grande exposição à diversas fontes de informações - muitas vezes não confiáveis - divulgadas por familiares, amigos, celebridades ou políticos (Beltrão et al., 2020).

Os defensores do movimento antivacina utilizam mídias sociais como WhatsApp, Twitter, Instagram e Facebook para promoverem sua retórica com temas polêmicos como a ameaça do excessivo controle governamental, manipulação de informações para lucro e informações de que vacinas causam efeitos adversos que são 
ocultados por órgãos superiores (Beltrão et al., 2020). No Brasil, os participantes deste movimento são, em sua maioria, aliados ao governo atual, visto que os próprios governantes são as principais fontes de divulgação de informações duvidosas sobre a pandemia e a vacina contra a COVID-19(Gramacho \& Turgeon, 2021; Camargo Jr., 2020).

Informações como "a vacina da China vai implantar um chip no seu organismo"; "a vacina vai alterar o DNA"; "A vacina da China tem efeitos graves que o governo chinês não quer divulgar"; "A China desenvolveu o vírus da Covid-19 em laboratório para lucrar com a cura" têm sido amplamente divulgadas pelas mídias como WhatsApp e Twitter (Gunaratne et al., 2019). Apoiadores do movimento antivacina utilizam "robôs" - softwares que fazem publicações automáticas e em massa nas mídias sociais e perfis falsos para postar essas informações. Como alguns estudos já demonstraram (Gunaratne et al., 2019; Camargo Jr, 2020; Vasconcellos-Silva et al., 2015), as informações antivacina na internet são em menor número do que as a favor das vacinas, porém os adeptos ao negacionismo acabam ganhando mais acessos pelo sensacionalismo e a utilização desses robôs para divulgação em massa.

$\mathrm{Na}$ perspectiva de consumidores de informação em saúde é mais prudente se unir aos rostos célebres e biografias que soam familiares do que, ao contrário, se orientar às médias das estatísticas oficiais, indeterminadoras e intangíveis por natureza (Vasconcellos-Silva et al., 2015). Os autores denominam isso como "efeitocelebridade": para as pessoas leigas é mais confiável a informação vinda de uma celebridade, do que de um especialista.

Em dezembro de 2019 a China teve seus primeiros casos de COVID-19 (WHO, 2020a). Em março de 2020 este vírus tornou-se rapidamente uma pandemia global que afetou mais de 185 países, infectando 90.353 .576 pessoas e provocando cerca de 1.936.410 de mortes em todo o mundo (WHO, 2020a). A pandemia sobrecarregou os sistemas hospitalares, fez despencar a atividade econômica em todo o mundo e causou medo na população mundial.

No início da pandemia, sem uma vacina ou tratamento em perspectiva, notícias falsas, suposições e teorias conspiratórias foram criadas acerca do novo coronavírus e sua origem. Na categoria conspiração, o movimento antivacina constrói afirmações como que o Bill Gates ou outros criaram a COVID-19 como um meio de desenvolver vacinas obrigatórias (Hotez, 2020). Na realidade de países que têm boa aceitação vacinal - Brasil, Argentina, Equador - criam histórias fatais acerca dos efeitos adverso 
das vacinas, aumentando o medo e a hesitação às vacinas (Cerda \& García, 2021; Urrunaga-Pastor et al., 2021; Beltrão et al., 2020). 


\section{Objetivos}

\subsection{Objetivo geral}

Avaliar e caracterizar a relação entre os fatores cognitivos e comportamentais que permeiam as percepções e atitudes em relação à vacina da COVID-19 em uma amostra da população brasileira em dois momentos da pandemia.

\subsection{Objetivos específicos}

1. Avaliar a relação entre personalidade e comportamento de hesitação à vacina;

2. Verificar relação entre fatores cognitivos e socioeconômicos;

3. Analisar a relação entre percepção e comportamento.

4. Analisar impactos a longo e curto prazo no controle da pandemia da COVID-19. 


\section{Material e método}

Foi conduzida uma pesquisa de caráter exploratório para avaliar fatores cognitivos e comportamentais envolvidos nas atitudes e percepções em relação à pandemia da COVID-19 e às vacinas-candidatas.

Critérios de inclusão: Participaram da pesquisa pessoas de 18 anos de idade ou mais, que falavam e compreendiam o idioma da pesquisa (português - Brasil) e residiam no Brasil.

Critérios de exclusão: Não participaram da pesquisa respondentes que residiam fora do Brasil ou que tiveram os questionários enviados de forma incompleta.

Riscos associados aos participantes: Responder aos questionários é considerado de risco mínimo, e somente pode ocasionar, se isso ocorrer, algum cansaço ou desconforto. Se, todavia, o participante eventualmente sentir alguma forma de desconforto relacionado ao questionário, poderá enviar um e-mail para o coordenador responsável pelo projeto de pesquisa. Assim considerando, o coordenador responsável se encarregará de lhe dar retorno a esse respeito o mais rapidamente possível.

Benefícios associados aos participantes: Os benefícios envolvem contribuição para a pesquisa brasileira, no sentido de colaborar para garantir dados atuais e relevantes para o período. Ademais, intervenções podem ser propostas a partir dos resultados e conclusões do estudo. Nesse sentido, a população poderá se preparar para outros eventos semelhantes.

Aspectos éticos: Esta pesquisa faz parte de um projeto guarda-chuva intitulado "Reações físicas, psicológicas e cognitivas à Covid-19" e está de acordo com os preceitos éticos, tendo sido submetida ao CONEP - Comissão Nacional de Ética em Pesquisa, o órgão institucional que tem por objetivo analisar os aspectos éticos e junto com o CEP - Comitê de Ética em Pesquisa que visa proteger o bem-estar dos indivíduos pesquisados. Número de aprovação do projeto (CAAE): 31703720.9.1001.0008.

\subsection{Fase 1}

Participantes: Na primeira fase do estudo a amostra foi composta por 201 respondentes aos questionários reunidos no "Módulo 7 - Atitudes e Comportamentos Antivacina" e 159 no "Módulo 8 - Escalas de Hesitação à Vacina, Inteligência Social Auto avaliada e Vulnerabilidade Social", totalizando 360 participantes nesta fase. Ambos os módulos foram ativados para a coleta de dados simultaneamente. É uma amostra 
majoritariamente feminina (73.61\%), com idade média de 35 anos de idade, ensino superior completo (41.67\%) e residentes no estado de São Paulo (52.78\%). Na Tabela 1 encontram-se detalhadas as características da amostra.

Tabela 1. Caracterização da amostra da Fase $1(n=360)$

\begin{tabular}{ccc}
\hline Variável & $\mathbf{N}$ & Porcentagem (\%) \\
\hline Feminino & 265 & $73.61 \%$ \\
Masculino & 95 & $26.39 \%$ \\
Idade (anos) & & \\
Média & 35 & - \\
Mediana & 31 & - \\
Moda & 25 & \\
Escolaridade & & $1.11 \%$ \\
Primário completo & 4 & $24.17 \%$ \\
Secundário completo & 87 & $41.67 \%$ \\
Graduação completo & 150 & $2.5 \%$ \\
Graduação incompleto & 9 & $28.61 \%$ \\
Pós-graduação completa & 103 & $1.94 \%$ \\
Pós-graduação incompleta & 7 & \\
Estado & & $52.78 \%$ \\
São Paulo (SP) & 190 & $12.5 \%$ \\
Minas Gerais (MG) & 45 & $16.67 \%$ \\
Sergipe (SE) & 60 & $0.28 \%$ \\
Acre (AC) & 1 & $0.56 \%$ \\
Alagoas (AL) & 2 & $0.83 \%$ \\
Amapá (AP) & 3 & $1.94 \%$ \\
Bahia (BA) & 7 & $0.28 \%$ \\
Distrito Federal (DF) & 1 & $0.28 \%$ \\
Espírito Santo (ES) & 3 & $1.67 \%$ \\
Goiás (GO) & 6 & $0.28 \%$ \\
Maranhão (MA) & 1 & $0.28 \%$ \\
Paraná (PR) & 1 & $0.56 \%$ \\
Pernambuco (PE) & 2 & $3.89 \%$ \\
Rio de Janeiro (RJ) & 14 & $5.00 \%$ \\
Rio Grande do Norte (RN) & 18 & $0.56 \%$ \\
Rio Grande do Sul (RS) & 2 & $0.56 \%$ \\
Roraima (RR) & & $0.28 \%$ \\
Rondônia (RO) & & \\
\hline & & \\
\hline & & \\
\hline
\end{tabular}

\section{Instrumentos de Pesquisa - Fase 1}

1. Inventário de Personalidade Narcisista - (IPN) - 16: O IPN-16 (Anexo A) consiste em um inventário com 16 afirmações, das quais o participante deve assinalar a que mais se aproxima de seu sentimento naquele momento. Se trata de um instrumento com 16 itens e duas afirmativas pareadas em cada item, das quais o respondente deve escolher uma. Apresenta uma consistência interna substancial (Alpha de Cronbach $=0.72$ ) (Ames, Rose \& Anderson, 2006). O inventário foi traduzido e adaptado para a língua portuguesa do Brasil. 
2. Escala de Auto-Relato de Credulidade: Se trata de uma escala de 12 itens tipo Likert e visa medir o quanto o participante realmente acredita que cada afirmação seja verdadeira em relação a sua forma de lidar com situações, pessoas e informações que chegam a ele no dia-a-dia (Teunisse et al., 2020). Cada item pode ser classificado de 1 (discordo fortemente) a 7 (concordo fortemente). O uso e tradução da escala para a língua portuguesa do Brasil foram autorizados pela autora. A escala (Anexo B) apresenta ótima consistência interna (Alpha de Cronbach $=0.83$ ).

3. Escala de Percepção à Vulnerabilidade à Doença Infecciosa: Consiste em uma escala (Anexo C) de 15 itens com pontuação tipo Likert que avalia 2 fatores, "Infectabilidade percebida de uma doença infecciosa" e "Aversão a germes" (Duncan et al., 2009). É pontuada no formato Likert com variação de 1 (discordo fortemente) a 7 (concordo fortemente) (Duncan et al., 2009). A escala apresenta uma boa consistência interna (Alpha de Cronbach = 0.69).

\section{Escala de Aderência às Teorias Conspiratórias Anti-Vacina (VCBS): A VCBS} (Anexo D) é uma escala que permite a avaliação e mensuração do quanto as pessoas podem acreditar - ou não - em teorias anti-vacina (Shapiro et al., 2016). É uma escala com 8 itens e pontuação tipo Likert, que varia de 1 (discordo fortemente) a 7 (concordo fortemente). A escala apresenta uma ótima consistência interna (Alpha de Cronbach = $0.88)$.

5. Escala de Atitudes Anti-Vacinação (ATVS): Consiste em uma escala de 12 itens para medir as atitudes em relação às vacinas, com pontuação tipo Likert que varia de 1 (concordo totalmente a 6 (discordo totalmente) (Martin \& Petrie, 2017). A escala (Anexo E) apresentou uma boa consistência interna (Alpha de Cronbach $=0.84)$.

6. Escala de Hesitação à Vacina (VHS): A VHS (Anexo F) é uma escala com 10 afirmações que vão avaliar o nível de hesitação à vacina (processo de tomada de decisão que depende no nível de compromisso do indivíduo com sua saúde, de sua cultura e na confiança que possui nas autoridades e profissionais da saúde). A pontuação é feita no modelo de escala Likert, variando de 1 (concordo totalmente) a 6 (discordo totalmente) (Shapiro et al., 2018).

7. Escala de Inteligência autoavaliada: Esta escala (Anexo G) avalia a percepção do indivíduo sobre sua própria inteligência. A pontuação varia de 1 (inteligência muito baixa) a 10 (inteligência muito alta) (Zajenkowski \& Czarna, 2015).

8. Escala de Inteligência Social: Constitui-se em 21 afirmações para avaliar 5 fatores de inteligência: manipulação social; habilidades sociais; empatia social; e extroversão; 
adaptabilidade social (Anexo H). É uma escala Likert, na qual a pontuação de cada afirmação varia de 1 (não me descreve) a 7 (me descreve bem) e possui 3 sub-escalas: Sub escala de processamento de informação social $(\mathrm{PS})($ Alpha de Cronbach $=0.81$ ); Sub. Escala de Consciência Social (CS) (Alpha de Cronbach $=0.79)$ e Sub escala de habilidades sociais (HS) Alpha de Cronbach = 0.86) (Silvera et al., 2001).

9. Escala de Vulnerabilidade Social: Esta escala (Anexo I) consiste em 15 itens com afirmações para avaliar a vulnerabilidade do indivíduo à exploração bem como seu nível de ingenuidade. Trata-se e uma escala tipo Likert de 4 pontos (Pinsker, McFarland \& Stone, 2011).

10. Questionário sociodemográfico: No questionário estruturado (Anexo J) serão abordadas questões relacionadas aos aspectos socioeconômicos; questões específicas ao isolamento social, vivências durante a pandemia e percepção a infecção pela Covid-19; hábitos de trabalho e higiene durante a pandemia; relação com as campanhas de vacinação promovidas pelo governo; e hábitos de saúde em 29 itens de múltipla escolha.

Antes de responder ao formulário, o participante teve que concordar com o Termo de Consentimento Livre e Esclarecido (TCLE) (Anexo K e Anexo L), visto que a participação nesta pesquisa foi voluntária.

\subsubsection{Procedimento de coleta Fase 1}

As escalas foram aplicadas de modo online pela plataforma Google Forms no período de 22 de julho de 2020 a 23 de outubro de 2020 - três meses após o início da pandemia da COVID-19 e período em que ainda havia uma rígida quarentena no Brasil e as vacinas-candidatas ainda estavam em fase de testes laboratoriais (OMS, 2020b). A coleta de dados ocorreu de forma não presencial e individual para cada participante. Os participantes foram convidados de maneira randomizada a participar da pesquisa por meio de e-mails e convites em redes sociais.

As escalas foram divididas em dois questionários online, que foram divulgados para a coleta de forma simultânea: as escalas INP-16, Escala de Auto-Relato de Credulidade, Escala de Percepção à Vulnerabilidade à Doença Infecciosa, Escala de Aderência às Teorias Antivacina e a Escala de Atitudes Antivacina foram respondidas no questionário "Módulo 7 - Atitudes e Comportamentos Anti-Vacina" e as escalas Escala de Hesitação à Vacina, Escala de Inteligência autoavaliada, Escala de 
Inteligência Social Autoavaliada, Escala de Vulnerabilidade Social e a Escala de Percepção à Vulnerabilidade às doenças infecciosas no "Módulo 8 - Escalas de Hesitação à Vacina, Inteligência Social Autoavaliada e Vulnerabilidade Social”. Os formulários foram divulgados para pessoas da comunidade acadêmica da FFCLRP USP e para a população brasileira geral por meio de anúncios nas redes sociais e em listas de e-mail.

\subsection{Fase 2}

Participantes: Na segunda fase do estudo a amostra foi composta por 100 participantes. É uma amostra com características semelhantes à da Fase 1 deste estudo: majoritariamente feminina (77\%), com idade média de 35.61 anos de idade, ensino superior completo (42\%) e residentes no estado de São Paulo (56\%). Na Tabela 2 encontram-se detalhadas as características da amostra.

Tabela 2. Caracterização da amostra Fase $2(n=100)$

\begin{tabular}{ccc}
\hline Variável & $\mathbf{N}$ & Porcentagem (\%) \\
\hline Feminino & 77 & $77 \%$ \\
Masculino & 23 & $23 \%$ \\
Idade (anos) & 35.61 & - \\
Média & 32 & - \\
Mediana & 25 & - \\
Moda & & \\
Escolaridade & 1 & $1 \%$ \\
Secundário completo & 42 & $42 \%$ \\
Graduação completo & 47 & \\
Pós-graduação completa & & $56 \%$ \\
Estado & 56 & $11 \%$ \\
São Paulo (SP) & 11 & $1 \%$ \\
Minas Gerais (MG) & 1 & $1 \%$ \\
Alagoas (AL) & 1 & $1 \%$ \\
Bahia (BA) & 1 & $2 \%$ \\
Distrito Federal (DF) & 2 & $13 \%$ \\
Paraná (PR) & 13 & $1 \%$ \\
Rio de Janeiro (RJ) & 1 & $3 \%$ \\
Rio Grande do Norte (RN) & 3 & 2 \\
Rio Grande do Sul (RS) & 2 & 2 \\
Pará (PA) & 2 & 1 \\
Ceará (CE) & 1 & \\
Amazonas (AM) & &
\end{tabular}




\section{Instrumentos de Pesquisa - Fase 2}

1. Escala de Percepção à Vulnerabilidade à Doença Infecciosa: Consiste em uma escala (Anexo C) de 15 itens com pontuação tipo Likert que avalia 2 fatores, "Infectabilidade percebida de uma doença infecciosa" e "Aversão a germes" (Duncan et al., 2009). É pontuada no formato Likert com variação de 1 (discordo fortemente) a 7 (concordo fortemente) (Duncan et al., 2009). A escala apresenta uma boa consistência interna (Alpha de Cronbach $=0.69$ ).

2. Escala de Aderência às Teorias Conspiratórias Anti-Vacina (VCBS): A VCBS (Anexo D) é uma escala que permite a avaliação e mensuração do quanto as pessoas podem acreditar - ou não - em teorias anti-vacina (Shapiro et al., 2016). É uma escala com 8 itens e pontuação tipo Likert, que varia de 1 (discordo fortemente) a 7 (concordo fortemente). A escala apresenta uma ótima consistência interna (Alpha de Cronbach = $0.88)$.

3. Escala de Atitudes Anti-Vacinação (ATVS): Consiste em uma escala de 12 itens para medir as atitudes em relação às vacinas, com pontuação tipo Likert que varia de 1 (concordo totalmente a 6 (discordo totalmente) (Martin \& Petrie, 2017). A escala (Anexo E) apresentou uma boa consistência interna (Alpha de Cronbach $=0.84$ ).

4. Escala de Hesitação à Vacina (VHS): A VHS (Anexo F) é uma escala com 10 afirmações que vão avaliar o nível de hesitação à vacina (processo de tomada de decisão que depende no nível de compromisso do indivíduo com sua saúde, de sua cultura e na confiança que possui nas autoridades e profissionais da saúde). A pontuação é feita no modelo de escala Likert, variando de 1 (concordo totalmente) a 6 (discordo totalmente) (Shapiro et al., 2018).

5. Questionário sociodemográfico: No questionário estruturado (Anexo $\mathrm{M}$ ) foram abordadas questões relacionadas aos aspectos socioeconômicos; hábitos de trabalho e higiene durante a pandemia; relação com as campanhas de vacinação promovidas pelo governo; e hábitos de saúde em 37 itens de múltipla escolha.

\subsubsection{Procedimento de coleta Fase 2}

As escalas foram aplicadas de modo online pela plataforma Google Forms no período de 14 de janeiro de 2021 a 20 de maio de 2021. O período de coleta da fase 2 deste estudo se caracterizava por ser o segundo ano da pandemia, a quarentena estava 
flexibilizada na maioria dos estados brasileiros e a vacinação contra a COVID-19 já havia sido iniciada em vários países, incluindo o Brasil (Ritchie et al., 2021).

A coleta de dados ocorreu de forma não presencial e individual para cada participante. Os participantes foram convidados, de maneira randomizada, a participar da pesquisa por meio de e-mails para a comunidade acadêmica da FFCLRP - USP e para a população brasileira geral por meio de anúncios nas redes sociais e em listas de e-mail.

Antes de responder ao formulário, o participante teve que concordar com o Termo de Consentimento Livre e Esclarecido (TCLE) (Anexo N), visto que a participação nesta pesquisa foi voluntária.

\subsection{Análise estatística dos dados}

Dados sociodemográficos

Foram analisados de forma descritiva utilizando o software Microsoft Office Excel 2007 para Windows, obtendo assim a frequência de respostas em números absolutos, porcentagens, médias e desvio-padrão

\section{Escalas e Inventários}

As escalas e inventários foram corrigidas para obtenção dos escores utilizando o software Microsoft Office Excel 2007 para Windows. Foi conduzida uma análise descritiva utilizando o software IBM SPSS Statistics 23 para Windows, de modo que foram obtidos os valores de frequência de respostas, média e desvio padrão.

\section{Análise Fatorial Exploratória (AFE)}

Foi realizada uma Análise Fatorial Exploratória nas escalas tipo Likert. Para a execução desta análise foram montadas tabelas com o número total de respondentes e as variáveis de cada escala, considerando o nível de análise de KMO e o teste de Bartlett. Com a análise foram obtidos o número de dimensões de cada instrumento pelo gráfico Scree plot e a correspondência rotativa de cada item dentro de cada escala. Nesta fase foi utilizado o software IBM SPSS Statistics 23 para Windows. 
Correlação de Pearson

Entre os fatores Aderência às Teorias Conspiratórias Antivacina (Shapiro et al., 2017) e a Escala de Atitudes Antivacinaçào (Martin \& Petrie, 2017); Escala de Hesitação à Vacina (Shapiro et al., 2018) e a Escala de Percepção à Vulnerabilidade a Doença Infecciosa (Duncan et al., 2009); Escala de Inteligência Social (Silvera et al, 2001) e Escala de Percepção à Vulnerabilidade a Doença Infecciosa (Duncan et al., 2009), foi feita uma análise de Correlação de Pearson com $p<0,05$. Para esta análise foi utilizado o software IBM SPSS Statistics 23 para Windows. 


\section{Resultados}

\subsection{Dados contínuos}

A Tabela 3 apresenta percentagens de respostas dos participantes, na Fase 1 do estudo, para as questões "Você já foi vacinado contra alguma doença infecciosa? (Vacinas obrigatórias: BCG; DTP e HIB; Hepatite B; Pneumocócica 10; VOHR; VOP; Meningocócica C; SCR ou Tríplice Viral)"; "Se você é adulto ou idoso, vacina-se todo ano contra a gripe?"; e "Você foi infectado com a Covid-19?", respetivamente

Tabela 3. Frequência absoluta e porcentagem do questionário sociodemográfico dos respondentes do Módulo 7 sobre vacinação e infecção pela COVID-19 $(n=201)$

\begin{tabular}{ccc}
\hline Questão & n & Porcentagem (\%) \\
\hline Vacinação doenças & Frequência Absoluta & Frequência Relativa \\
infeciosas & 192 & \\
Sim & 5 & $95.52 \%$ \\
Não & 4 & $2.49 \%$ \\
Não sei & 111 & $1.99 \%$ \\
Vacinação anual (Gripe) & 82 & $55.22 \%$ \\
Sim & 8 & $40.80 \%$ \\
Não & & $3.98 \%$ \\
Não sei & 10 & 4.98 \\
Sim & 102 & 50.75 \\
Não & 89 & 44.27 \\
Não sei & &
\end{tabular}

A Tabela 4 apresenta percentagens de respostas dos participantes na Fase 1 do estudo para as questões, "Você já foi vacinado contra alguma doença infecciosa? (Vacinas obrigatórias: BCG; DTP e HIB; Hepatite B; Pneumocócica 10; VOHR; VOP; Meningocócica C; SCR ou Tríplice Viral)"; "Se você é adulto ou idoso, vacina-se todo ano contra a gripe?"; e "Você foi infectado com a Covid-19?", respectivamente.

Tabela 4. Frequência absoluta e porcentagem do questionário sociodemográfico dos respondentes do Módulo 8 sobre vacinação e infecção pela COVID-19 (n = 159)

\begin{tabular}{ccc}
\hline Questão & n & Porcentagem (\%) \\
\hline Vacinação doenças & Frequência Absoluta & Frequência Relativa \\
infecciosas & & \\
Sim & 147 & $92.45 \%$ \\
Não & 7 & $4.40 \%$ \\
Não sei & 5 & $3.15 \%$ \\
Vacinação anual (Gripe) & & \\
Sim & 81 & $50.94 \%$ \\
Não & 74 & $46.54 \%$ \\
Não sei & 4 & $2.52 \%$ \\
Simfectado pela COVID-19 & 7 & \\
Não & 69 & $4.40 \%$ \\
Não sei & 83 & $52.39 \%$ \\
\hline
\end{tabular}


Fase 2

Os resultados dessa fase do estudo se deram 6 meses após a coleta de dados da Fase 1, de janeiro a maio de 2021. Neste período o Brasil entrava na segunda onda da pandemia da COVID-19 e, assim como outros países, já havia iniciado a vacinação.

A Tabela 5 a apresenta as porcentagens de respostas dos participantes, na Fase 2 do estudo, para as questões, "Você já foi vacinado contra alguma doença infecciosa? (Vacinas obrigatórias: BCG; DTP e HIB; Hepatite B; Pneumocócica 10; VOHR; VOP; Meningocócica C; SCR ou Tríplice Viral)"; "Se você é adulto ou idoso, vacina-se todo ano contra a gripe?"; e "Você foi infectado com a Covid-19?"; "Você irá se vacinar contra a COVID-19?”; e “A origem da vacina (país e/ou laboratório) contra a COVID19 tem influência na sua decisão para se vacinar?", respectivamente.

Tabela 5. Frequência absoluta e porcentagem do questionário sociodemográfico dos respondentes da Fase 2 sobre vacinação e infecção pela COVID-19 $(n=100)$.

\begin{tabular}{|c|c|c|}
\hline Questão & $\mathbf{n}$ & Porcentagem (\%) \\
\hline \multicolumn{2}{|l|}{ infecciosas } & Frequência Relativa \\
\hline Sim & 94 & $94.00 \%$ \\
\hline Não & 5 & $5.00 \%$ \\
\hline Não sei & 1 & $1.00 \%$ \\
\hline \multicolumn{3}{|l|}{ Vacinação anual (Gripe) } \\
\hline Sim & 57 & $57.00 \%$ \\
\hline Não & 41 & $41.00 \%$ \\
\hline Não sei & 2 & $2.00 \%$ \\
\hline \multicolumn{3}{|c|}{ Infectado pela COVID-19 } \\
\hline Sim & 18 & $18.00 \%$ \\
\hline Não & 60 & $60.00 \%$ \\
\hline Não sei & 22 & $22.00 \%$ \\
\hline \multicolumn{3}{|l|}{ Irá vacinar contra a } \\
\hline Sim & 98 & $98.00 \%$ \\
\hline Não & 2 & $2.00 \%$ \\
\hline \multicolumn{3}{|c|}{$\begin{array}{c}\text { Tipo da vacina influencia } \\
\text { na decisão }\end{array}$} \\
\hline Sim & 20 & $20.00 \%$ \\
\hline Não & 80 & $80.00 \%$ \\
\hline \multicolumn{3}{|l|}{ Isolamento social } \\
\hline Sim & 68 & $68.00 \%$ \\
\hline Não & 32 & $32.00 \%$ \\
\hline
\end{tabular}




\subsection{Análise Descritiva}

\subsubsection{Escores e frequências estatísticas}

Fase 1

A tabela 6 apresenta os escores e a dos participantes que responderam aos questionários presentes no Módulo 7, o que representa n=201 participantes da amostra total da primeira fase do estudo. Análise descritiva de frequência de gênero sobre os escores totais das escalas.

Tabela 6. Frequência de gênero e análise estatística das escalas INP-16, Credulidade, Percepção à Vulnerabilidade à Doença; Aderência às Teorias Conspiratórias, e Atitudes Antivacina dos respondentes do Módulo 7 (N=201)

\begin{tabular}{|c|c|c|c|}
\hline & Mulher(n=151) & Homem(n=50) & Amostra \\
\hline \multicolumn{4}{|l|}{ INP-16 } \\
\hline Média & 7.32 & 7.70 & 7.41 \\
\hline Mediana & 7 & 7 & 7 \\
\hline Moda & 7 & 8 & 7 \\
\hline Min & 3 & 4 & 3 \\
\hline Máx & 12 & 14 & 14 \\
\hline \multicolumn{4}{|c|}{ Credulidade } \\
\hline Média & 33.25 & 31.32 & 32.77 \\
\hline Mediana & 31 & 29.5 & 31 \\
\hline Moda & 36 & 32 & 24 \\
\hline Min & 12 & 12 & 12 \\
\hline Máx & 74 & 74 & 74 \\
\hline \multicolumn{4}{|c|}{ Percepção à } \\
\hline \multicolumn{4}{|c|}{ Vulnerabilidade à Doença } \\
\hline Média & 67.87 & 64.4 & 67 \\
\hline Mediana & 69 & 66 & 69 \\
\hline Moda & 69 & 68 & 69 \\
\hline Min & 28 & 39 & 28 \\
\hline Máx & 97 & 88 & 97 \\
\hline \multicolumn{4}{|c|}{ Aderência às Teorias } \\
\hline \multicolumn{4}{|c|}{ Conspiratórias } \\
\hline Média & 13.52 & 11.88 & 13.11 \\
\hline Mediana & 11 & 11 & 11 \\
\hline Moda & 8 & 8 & 8 \\
\hline Min & 8 & 8 & 8 \\
\hline Máx & 41 & 39 & 41 \\
\hline \multicolumn{4}{|c|}{ Atitudes Antivacina } \\
\hline Média & 27.60 & 24.82 & 26.92 \\
\hline Mediana & 26 & 24 & 25 \\
\hline Moda & 24 & 25 & 24 \\
\hline Min & 12 & 12 & 12 \\
\hline Máx & 65 & 62 & 65 \\
\hline
\end{tabular}


A Tabela 7 apresenta os escores e a dos participantes que responderam aos questionários presentes no Módulo 8, o que representa $n=159$ participantes da amostra total da primeira fase do estudo. Análise descritiva de frequência de gênero sobre os escores totais das escalas.

Tabela 7. Frequência de gênero e análise estatística das escalas VHS, Escala de Inteligência Autoavaliada, Escala de Percepção à Vulnerabilidade à Doença Infecciosa, Escala de Inteligência Social e Escala de Vulnerabilidade Social dos respondentes do Módulo $8(n=159)$

\begin{tabular}{|c|c|c|c|}
\hline & Mulher(n=114) & $\operatorname{Homem}(n=45)$ & Amostra \\
\hline \multicolumn{4}{|l|}{ Hesitação } \\
\hline Média & 40.27 & 40.58 & 40.35 \\
\hline Mediana & 41.5 & 42 & 42 \\
\hline Moda & 42 & 44 & 42 \\
\hline Min & 19 & 23 & 19 \\
\hline Máx & 49 & 46 & 49 \\
\hline \multicolumn{4}{|c|}{ Inteligência Autoavaliada } \\
\hline Média & 6.89 & 6.96 & 6.91 \\
\hline Mediana & 7 & 7 & 7 \\
\hline Moda & 9 & 7 & 6 \\
\hline Min & 3 & 5 & 3 \\
\hline Máx & 10 & 10 & 10 \\
\hline \multicolumn{4}{|c|}{ Percepção à } \\
\hline \multicolumn{4}{|c|}{ Vulnerabilidade à Doença } \\
\hline Média & 68.25 & 70.77 & 68.97 \\
\hline Mediana & 68 & 74 & 69 \\
\hline Moda & 77 & 74 & 74 \\
\hline Min & 39 & 45 & 39 \\
\hline Máx & 99 & 92 & 99 \\
\hline \multicolumn{4}{|c|}{ Inteligência Social } \\
\hline Média & 96.84 & 91.64 & 95.37 \\
\hline Mediana & 98 & 92 & 95 \\
\hline Moda & 109 & 93 & 89 \\
\hline Min & 53 & 60 & 53 \\
\hline Máx & 134 & 120 & 134 \\
\hline \multicolumn{4}{|c|}{ Vulnerabilidade Social } \\
\hline Média & 7.64 & 5.76 & 7.11 \\
\hline Mediana & 7 & 5 & 6 \\
\hline Moda & 8 & 3 & 4 \\
\hline Min & 0 & 0 & 0 \\
\hline Máx & 32 & 25 & 32 \\
\hline
\end{tabular}




\section{Fase 2}

A Tabela 8 mostra uma análise de frequência de gênero e estatística dos escores dos participantes desta fase do estudo.

Tabela 8. Frequência de gênero e análise estatística das escalas Hesitação a Vacina, Percepção à Vulnerabilidade à Doença; Aderência às Teorias Conspiratórias, e Atitudes Antivacina (n= 100)

\begin{tabular}{|c|c|c|c|}
\hline & Mulher & Homem & Amostra \\
\hline \multicolumn{4}{|l|}{ Hesitação } \\
\hline Média & 41.77 & 40.65 & 41.52 \\
\hline Mediana & 42 & 41 & 42 \\
\hline Moda & 42 & 43 & 42 \\
\hline Min & 33 & 20 & 20 \\
\hline Máx & 51 & 46 & 51 \\
\hline \multicolumn{4}{|c|}{ Percepção à } \\
\hline \multicolumn{4}{|c|}{ Vulnerabilidade à Doença } \\
\hline Média & 71.16 & 66.95 & 70.20 \\
\hline Mediana & 71 & 71 & 71 \\
\hline Moda & 71 & 71 & 71 \\
\hline Min & 41 & 29 & 29 \\
\hline Máx & 98 & 97 & 98 \\
\hline \multicolumn{4}{|c|}{ Aderência às Teoris } \\
\hline \multicolumn{4}{|c|}{ Conspiratórias } \\
\hline Média & 12.32 & 12.04 & 12.26 \\
\hline Mediana & 10 & 11 & 10.5 \\
\hline Moda & 8 & 14 & 8 \\
\hline Min & 8 & 8 & 8 \\
\hline Máx & 48 & 23 & 48 \\
\hline \multicolumn{4}{|c|}{ Atitudes Antivacina } \\
\hline Média & 26.93 & 26.04 & 26.73 \\
\hline Mediana & 25 & 23 & 25 \\
\hline Moda & 19 & 19 & 19 \\
\hline Min & 12 & 12 & 12 \\
\hline Máx & 60 & 72 & 72 \\
\hline
\end{tabular}

\subsubsection{Correlação de Pearson}

Foram feitas as análises de correlação de Pearson entre escalas que, de acordo com a literatura (Camargo Jr, 2020; Taylor, 2019; Shapiro et al., 2018, 2016; Duncan et al., 2009; WHO, 2013), possuem fatores que podem apresentar alguma correlação entre si.

As escalas Atitudes Antivacina e Escala de Aderência às Teorias Conspiratórias Antivacina apresentaram correlação média com $\mathrm{p}<0,01$, como mostra a Tabela 9. 
Tabela 9. Correlação entre as escalas Aderência às Teorias Conspiratórias, e Atitudes Antivacina $\operatorname{com} p<0,01$

\begin{tabular}{|c|c|c|c|}
\hline \multicolumn{4}{|c|}{ Correlações } \\
\hline & & ATITUDES & TEORIAS \\
\hline ATITUDES & Correlação de Pearson & 1 &, $468^{* *}$ \\
\hline \multirow[t]{2}{*}{ ANTIVACINA } & Sig. (bilateral) & & ,000 \\
\hline & $\mathrm{N}$ & 201 & 201 \\
\hline TEORIAS & Correlação de Pearson &, $468^{* *}$ & 1 \\
\hline \multirow[t]{2}{*}{ CONSPIRATÓRIAS } & Sig. (bilateral) &, 000 & \\
\hline & $\mathrm{N}$ & 201 & 201 \\
\hline
\end{tabular}

As escalas Atitudes Antivacina e Escala de Aderência às Teorias Conspiratórias Antivacina mostraram alguns pontos de convergência no gráfico de dispersão, como mostra a Figura 3, com uma correlação direta.

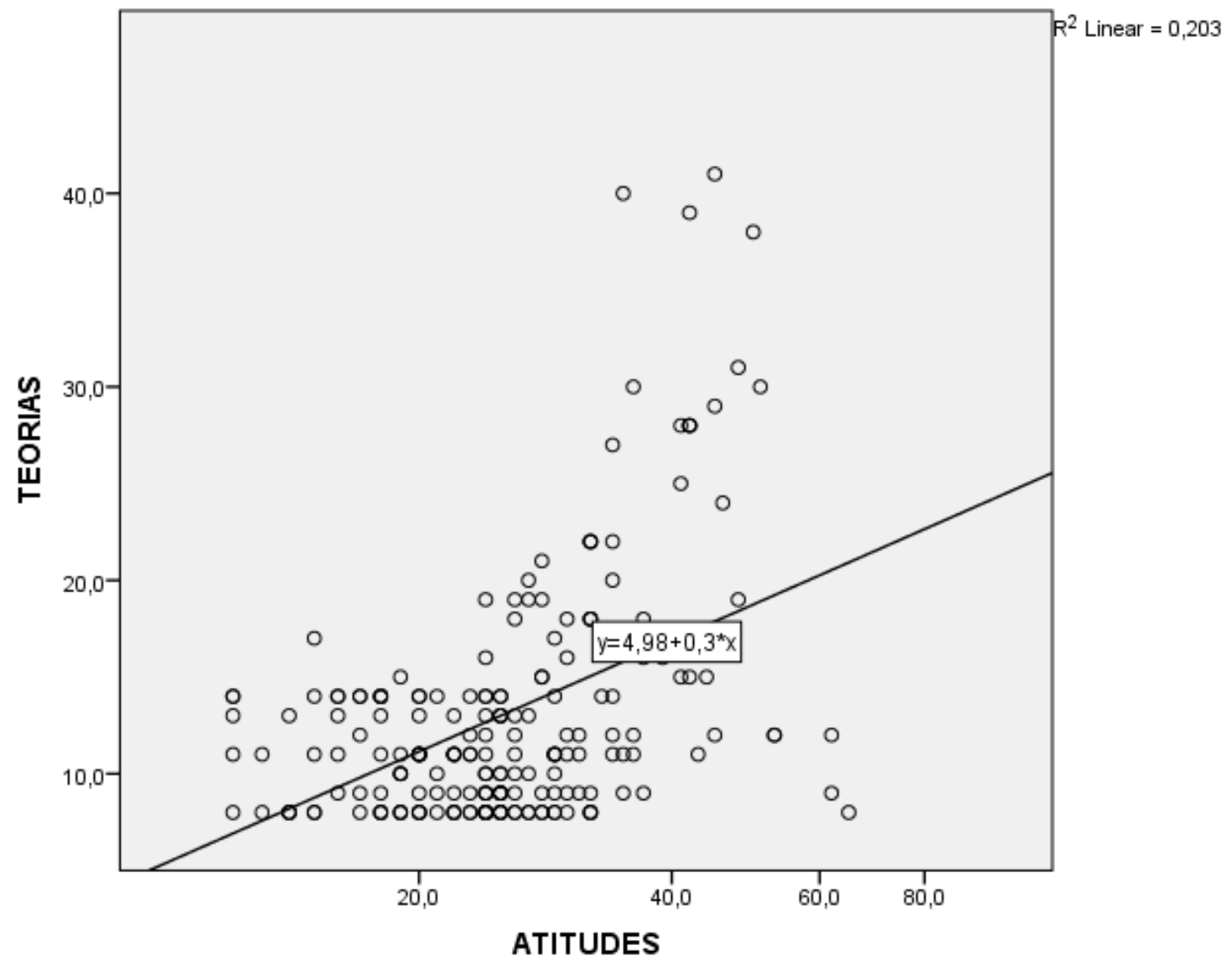

Gráfico 1. Gráfico de dispersão da Correlação de Perason entre a Escala de Aderência às Teorias Conspiratórias (y) e a Escala de Atitudes Antivacina (x) $\operatorname{com} \mathbf{p}<0.01$. 
A análise para correlação foi feita entre as escalas INP-16 e a Escala de Aderência às Teorias Conspiratórias. No entanto, não foi encontrada nenhuma correlação entre estes fatores, como mostra a Tabela 10.

Tabela 10. Análise de Correlação de Pearson entre as escalas INP-16 Aderência às Teorias Conspiratórias com $p<0,01$

\begin{tabular}{lccc}
\hline & \multicolumn{1}{c}{ Correlações } & & \\
\hline INP-16 & & INP-16 & Teorias Conspiratórias \\
& Correlação de Pearson & 1 &, 082 \\
& Sig. (bilateral) & &, 247 \\
Teorias & $\mathrm{N}$ & 201 & 201 \\
Conspiratórias & Correlação de Pearson &, 082 & 1 \\
& Sig. (bilateral) &, 247 & \\
& $\mathrm{~N}$ & 201 & 201 \\
\hline
\end{tabular}

A análise para correlação foi feita entre as escalas INP-16 e a Escala de Atitudes Antivacina. No entanto, não foi encontrada nenhuma correlação fortemente significativa entre estes fatores, como mostra a Tabela 11.

Tabela 11. Análise de Correlação de Pearson entre as escalas INP-16 e Atitudes Antivacina com $p<$ 0,01

\begin{tabular}{lccc}
\hline & \multicolumn{1}{c}{ Correlações } & \\
\hline INP-16 & INP-16 & Atitudes Antivacina \\
& Correlação de Pearson & 1 &,- 137 \\
& Sig. (bilateral) & &, 052 \\
Atitudes & $\mathrm{N}$ & 201 & 201 \\
Antivacina & Correlação de Pearson &,- 137 & 1 \\
& Sig. (bilateral) &, 052 & \\
& $\mathrm{~N}$ & 201 & 201 \\
\hline
\end{tabular}

A análise para correlação foi feita entre as escalas Escala de Hesitação à Vacina e a Escala de Percepção à Vulnerabilidade à Doença Infecciosa. A análise apresentou uma correlação. Significativa, mas fraca entre estes fatores, como mostra a Tabela 12. 
Tabela 12. Análise de Correlação de Pearson entre as escalas Hesitação a Vacina, Percepção à Vulnerabilidade à Doença com $p<0,01$

\begin{tabular}{lccc}
\hline \multicolumn{4}{c}{ Correlações } \\
\hline Hesitação à Vacina & Hesitação & Percepção \\
& Correlação de Pearson & 1 &, $221^{* *}$ \\
& Sig. (bilateral) & &, 005 \\
Percepção à Doença & $\mathrm{N}$ & 159 & 159 \\
& Correlação de Pearson &, $221^{* *}$ & 1 \\
& Sig. (bilateral) &, 005 & \\
& $\mathrm{~N}$ & 159 & 159 \\
\hline
\end{tabular}

**. A correlação é significativa no nível 0,01 (bilateral).

As escalas Escala de Hesitação à Vacina e a Escala de Percepção à Vulnerabilidade à Doença Infecciosa mostraram alguns pontos de convergência no gráfico de dispersão, como mostra o Gráfico 2, com uma correlação direta.

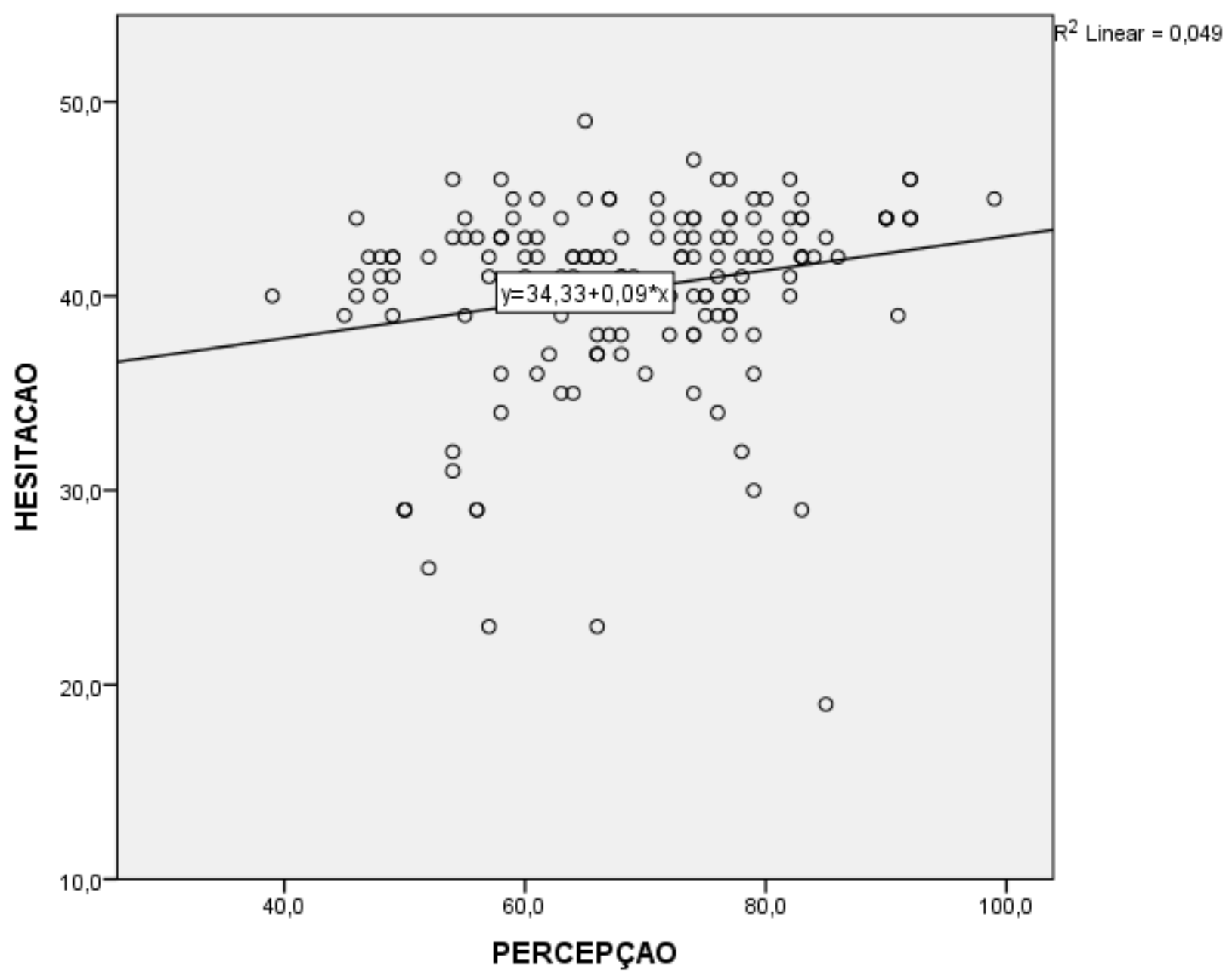

Gráfico 2. Gráfico de dispersão da Correlação de Pearson entre as escalas Hesitação a Vacina(y) e Percepção à Vulnerabilidade à Doença $(x)$ com $p<0,01$ 


\subsection{Análise fatorial exploratória}

Foi realizada uma análise fatorial exploratória de forma a estudar a validade das versões traduzidas e adaptadas das escalas. Para confirmar a validade, utilizou-se o critério do Gráfico Escarpa (Scree plot), identificando o ponto de inflexão da curva, considerando o número de fatores.

\section{Escala de Auto-Relato de Credulidade:}

Tabela 13. Estudo da validade da Escala de Auto-Relato de Credulidade a partir do critério Kaiser

\begin{tabular}{cccc}
\hline KMO & Teste de Bartlett $(\mathbf{p}-$ value $)$ & $\mathbf{N}^{\mathbf{0}}$ de Dimensões & Variância \\
\hline $\mathbf{0 . 8 8}$ & $<0.001$ & 2 & $60.20 \%$
\end{tabular}

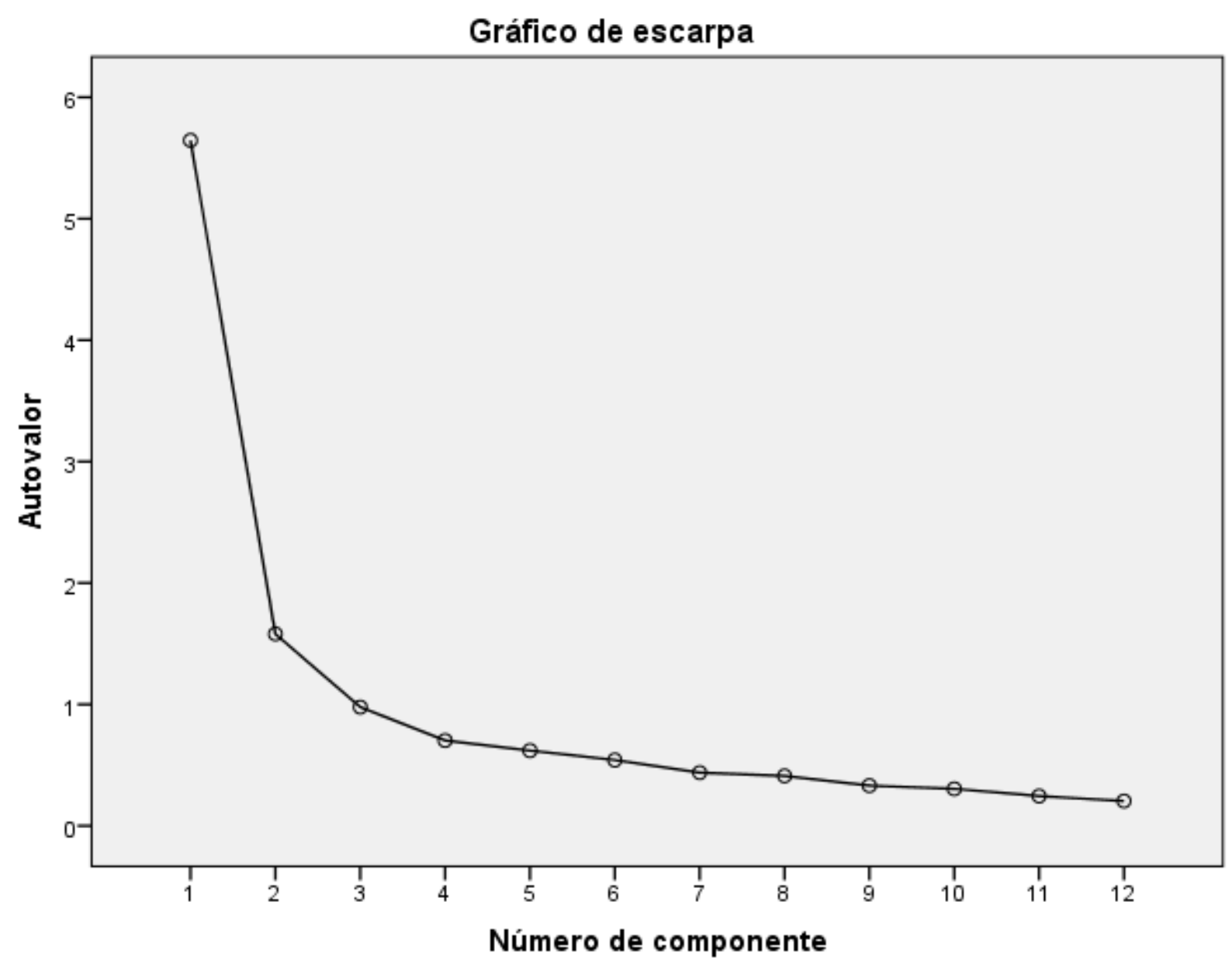

Gráfico 3. Gráfico de Escarpa da Análise Fatorial Exploratória da Escala de auto-relato de credulidade 
Tabela 14. Matriz de Componente rotativa da Escala de Auto-Relato de Credulidade

Matriz de componente rotativa ${ }^{\mathrm{a}}$

Componente

2

2. Geralmente sou rápido em perceber quando alguém está tentando me trapacear.

$-, 879 \quad-, 114$

4. Percebo rapidamente quando alguém está me passando a perna.

$-, 777 \quad-, 084$

1. Eu sou muito experto quando alguém está tentando me enganar

$-, 770 \quad-, 193$

5. Geralmente, eu levo um tempo para "cair a ficha" (detectar) quando alguém está me enganando.

,742 ,216

3. Sou muito lento em perceber quando alguém está me enganando.

,731 269

6. Não sou tão bom em ler os sinais de que alguém está tentando me manipular.

,700 237

11. As pessoas pensam que sou uma pessoa um pouco ingênua.

,118 ,732

9. Meus amigos acham que eu sou facilmente enganado.

,423 ,704

8. Se é provável que alguém caia num golpe ou farsa, esse alguém sou eu.

,401 ,680

10. No geral, sou facilmente manipulado.

,440 ,670

7. Minha família acha que sou um alvo fácil para os golpistas.

,378 ,631

12. Eu acho que sou mais crédulo que a pessoa média.

$-, 159 \quad 626$ 
Escala de Percepção à Vulnerabilidade à Doença Infecciosa:

Foi realizada uma análise fatorial exploratória de forma a estudar a validade das versões traduzidas e adaptadas das escalas.

Tabela 15. Estudo da validade da Escala de Percepção à Doença Infecciosa a partir do critério Kaiser

\begin{tabular}{cccc}
\hline KMO & Teste de Bartlett $(\mathbf{p}-$ value $)$ & $\mathbf{N}^{\mathbf{o}}$ de Dimensões & Variância \\
\hline $\mathbf{0 . 7 6}$ & $<0.001$ & 3 & $50.57 \%$
\end{tabular}

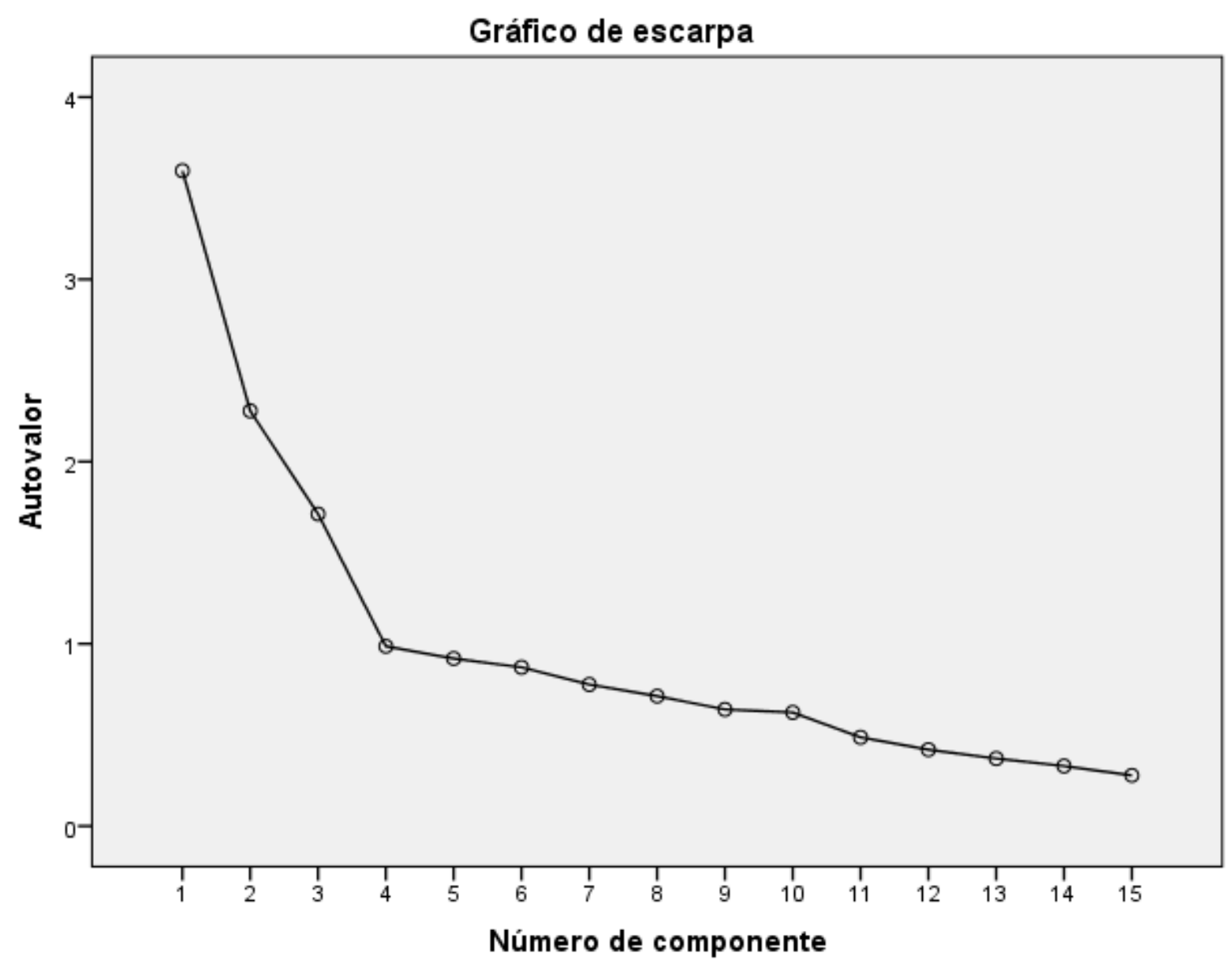

Gráfico 4. Gráfico de Escarpa da Análise Fatorial Exploratória da Escala de percepção à vulnerabilidade à doença infecciosa 
Tabela 16. Matriz de Componente rotativa da Escala de Percepção à Doença Infecciosa

\section{Matriz de componente rotativa ${ }^{\mathrm{a}}$}

6. Eu tenho um histórico de ser vulnerável à doenças infecciosas

8. Em geral, eu pego resfriados, gripes e outras doenças com muita facilidade.

10. É mais provável que eu pegue uma doença infeciosa do que as pessoas ao meu redor.

2. Se tem uma doença se espalhando, eu vou ser contaminado.

Componente

15. Evito usar telefones públicos, celulares de outras pessoas, devido ao risco de pegar algo da.

7. Prefiro lavar as mãos logo após apertar a mão de alguém.

3. Não me importo em compartilhar uma garrafa de água com um amigo.

\begin{tabular}{lll}
$\mathbf{1}$ & $\mathbf{2}$ & $\mathbf{3}$ \\
\hline 851 &, 098 &,- 011 \\
, 841 &, 067 &,- 048
\end{tabular}

9. Não gosto de usar roupas usadas porque não sei como era a pessoa que as vestiu no passado.

1. Realmente me incomoda quando as pessoas espirram sem cobrir a boca.

4. Não gosto de escrever com um lápis que alguém obviamente tenha mastigado.

12. É improvável que eu pegue um resfriado, gripe ou outra doença,

$, 823 \quad, 001 \quad-, 044$

,493 ,058 -,306

$, 043 \quad, 807 \quad 032$ mesmo que elas estejam ocorrendo.

14. Meu sistema imunológico me protege da maioria das doenças que

$, 159 \quad, 780 \quad-, 069$

$, 055 \quad-, 643 \quad, 143$

, 132 , 269 outras pessoas sofrem.

5. Minhas experiências passadas me fazem acreditar que não tenho

$\begin{array}{lll}-, 063 & , 503 \quad-, 139\end{array}$

$, 121 \quad, 476 \quad-, 110$

$-, 263 \quad-, 005 \quad, 696$

$-, 389 \quad-, 072 \quad, 681$

probabilidade de ficar doente, mesmo quando meus amigos estão doentes.

11. Minhas mãos não ficam sujas depois de tocar em dinheiro.

$-, 292 \quad-, 264 \quad, 584$

13. Não fico ansioso por estar perto de pessoas doentes. 
Escala de Aderência às Teorias Conspiratórias Anti-Vacina (VCBS):

Tabela 17. Estudo de validade da VCBS a partir do critério Kaiser

KMO Teste de Bartlett ( $\mathbf{p}$ - value) $\quad \mathbf{N}^{\mathbf{o}}$ de Dimensões $\quad$ Variância

$<0.001$

2

$71.29 \%$

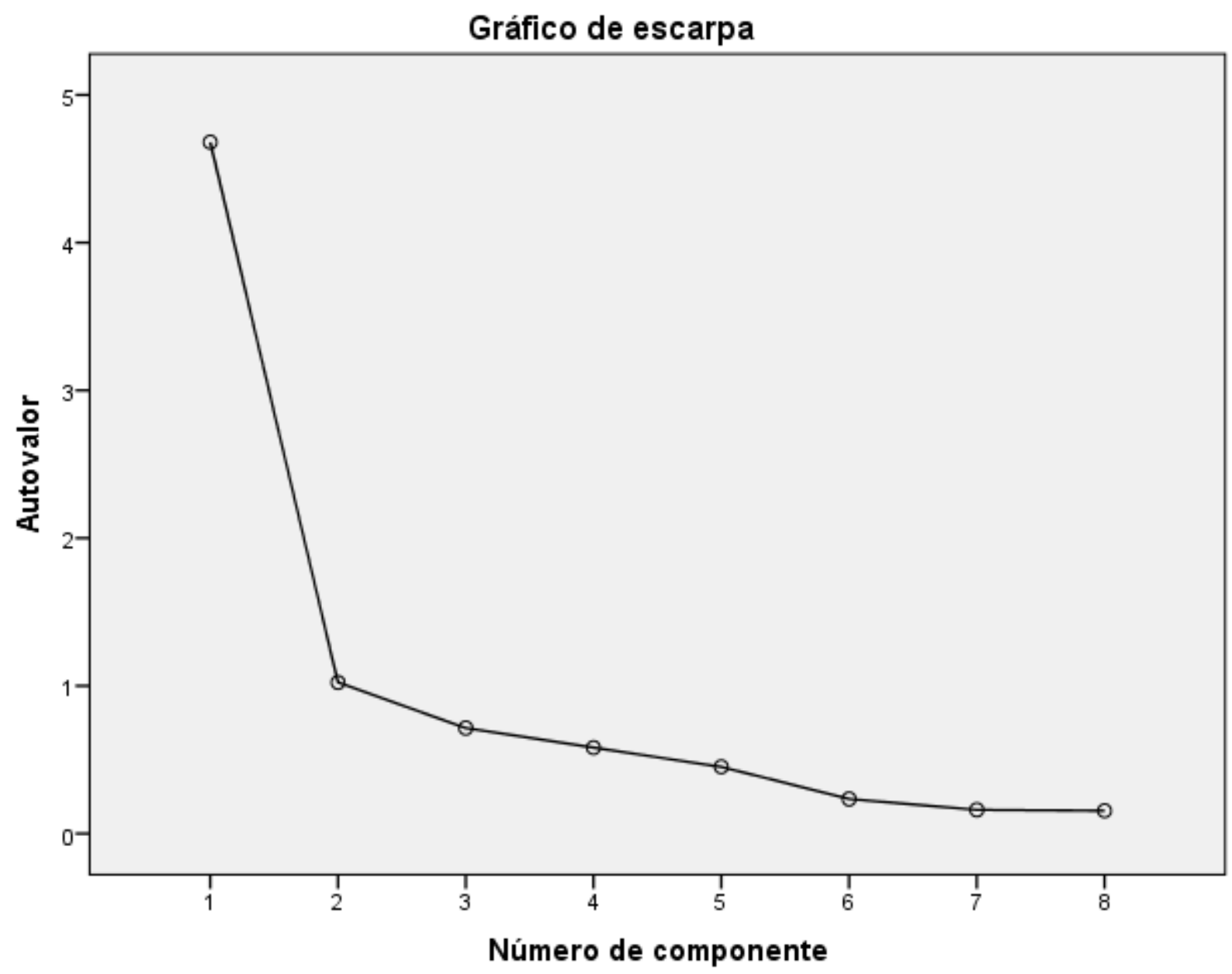

Gráfico 5. Gráfico de Escarpa da Análise Fatorial Exploratória da Escala de Aderência às Teorias Conspiratórias Anti-Vacina 
Tabela 18. Matriz de Componente rotativa da Escala VCBS

\section{Matriz de componente rotativa ${ }^{a}$}

\begin{tabular}{lll}
\hline & \multicolumn{2}{l}{ Componente } \\
$\begin{array}{l}\text { 8. A vacina da gripe permite ao governo monitorar os idosos por } \\
\text { meio da implantação de pequenos dispositivos de rastreamento. }\end{array}$ & \multicolumn{1}{c}{$\mathbf{2}$} \\
$\begin{array}{l}\text { 3. Pequenos dispositivos são colocados em vacinas a fim de } \\
\text { rastrear indivíduos. }\end{array}$ &, 876 &,- 065 \\
$\begin{array}{l}\text { 7. Pequenos dispositivos são implantados em vacinas para a } \\
\text { realização de experimentos de controle da mente. }\end{array}$ &, 873 \\
$\begin{array}{l}\text { 6. O governo está tentando ocultar o vínculo entre vacinas e } \\
\text { autismo. }\end{array}$ &, 801 \\
$\begin{array}{l}\text { 4. Companhias farmacêuticas, cientistas e acadêmicos trabalham } \\
\text { em conjunto para ocultar os perigos associados às vacinas. }\end{array}$ &, 784 \\
$\begin{array}{l}\text { 2. Vacinas são prejudiciais, e esse fato é ocultado do público. } \\
\text { 1. Imunizações permitem ao governo rastrear e controlar pessoas. } \\
\text { 5. Vacinas não sofrem modificações. }\end{array}$ &, 682 \\
\hline
\end{tabular}


Escala de Atitudes Anti-Vacinação (ATVS):

Tabela 19. Estudo de validade da escala de Atitudes Anti-vacinação a partir do critério Kaiser

\begin{tabular}{cccc}
\hline KMO & Teste de Bartlett $(\mathbf{p}-$ value $)$ & $\mathbf{N}^{\mathbf{0}}$ de Dimensões & Variância \\
\hline $\mathbf{0 . 8 2}$ & $<0.001$ & 3 & $70.93 \%$
\end{tabular}

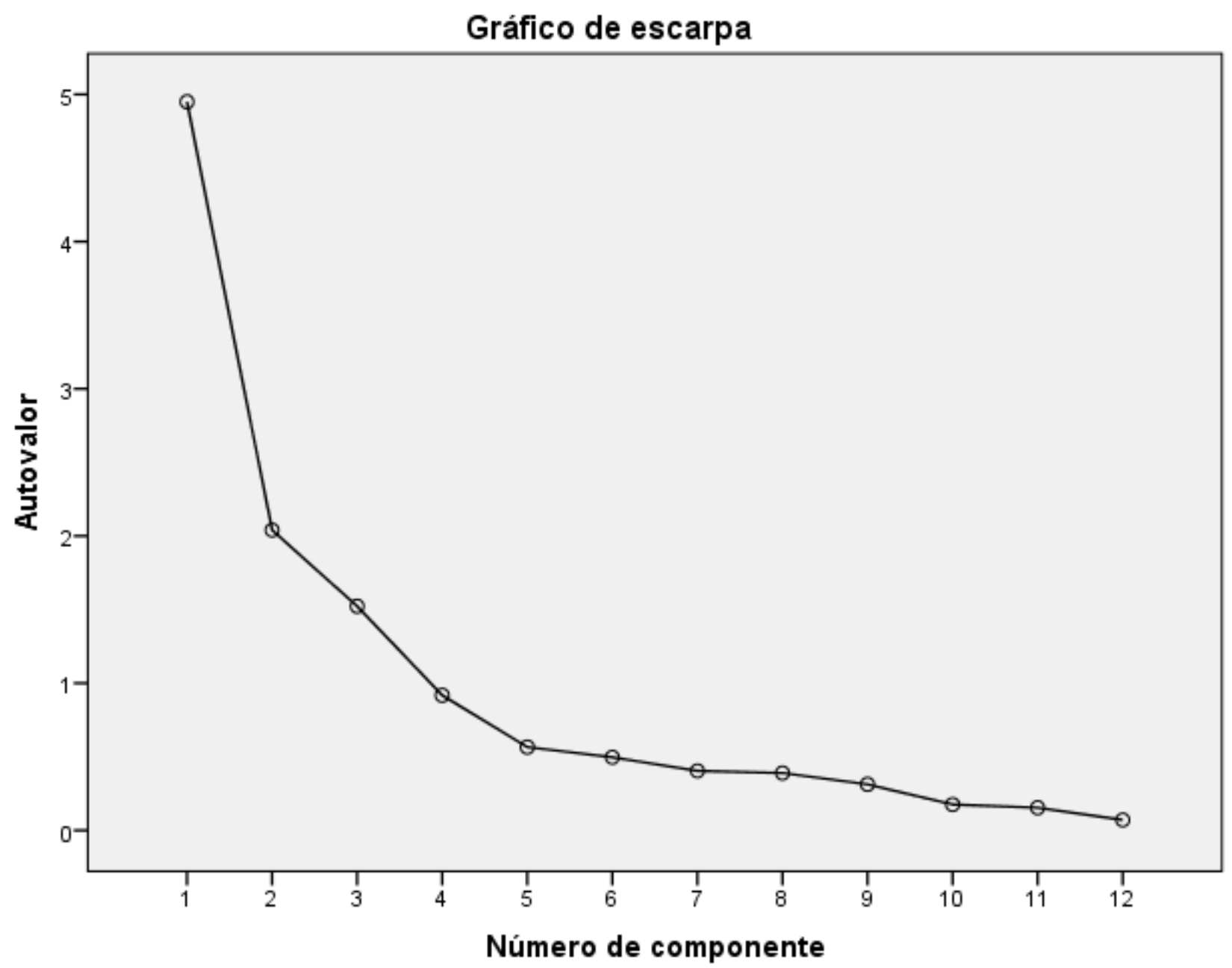

Gráfico 6. Gráfico de Escarpa da Análise Fatorial Exploratória da Escala de Atitudes AntiVacinação 
Tabela 20. Matriz de Componente rotativa da Escala de Atitudes Antivacina

Matriz de componente rotativa ${ }^{a}$

\begin{tabular}{|c|c|c|c|}
\hline & \multicolumn{3}{|c|}{ Componente } \\
\hline & 1 & 2 & 3 \\
\hline $\begin{array}{l}\text { 12. Ser exposto a doenças naturalmente é mais seguro para o sistema } \\
\text { imunológico do que ser exposto através da vacinação. }\end{array}$ & ,862 &,- 167 & 130 \\
\hline $\begin{array}{l}\text { 11. A exposição natural a vírus e germes oferece a proteção mais } \\
\text { segura. }\end{array}$ & 813 &, 174 & ,048 \\
\hline 10. A imunidade natural dura mais que uma vacinação. & ,775 & 007 & 100 \\
\hline $\begin{array}{l}\text { 8. As autoridades promovem a vacinação para ganho financeiro, não } \\
\text { para a saúde das pessoas. }\end{array}$ & ,730 &,- 301 &,- 041 \\
\hline 9. Os programas de vacinação são um grande golpe. & 667 &,- 411 &,- 063 \\
\hline $\begin{array}{l}\text { 7. As vacinas dão muito lucro para empresas farmacêuticas, mas não } \\
\text { fazem muito para pessoas comuns. }\end{array}$ & 604 &,- 229 & 265 \\
\hline 3. Sinto-me protegido depois de ser vacinado. &,- 224 & ,938 &,- 033 \\
\hline 1. Sinto-me seguro depois de ser vacinado. &,- 195 & ,914 & ,004 \\
\hline $\begin{array}{l}\text { 2. Posso confiar em vacinas para interromper a disseminação doenças } \\
\text { infecciosas graves. }\end{array}$ &,- 262 & 910 &,- 029 \\
\hline 5. As vacinas podem causar problemas imprevistos em crianças. & , 162 & 031 & ,806 \\
\hline 6. Preocupo-me com os efeitos desconhecidos das vacinas no futuro. & , 149 &, 162 & ,786 \\
\hline $\begin{array}{l}\text { 4. Embora a maioria das vacinas pareça ser segura, pode haver } \\
\text { problemas que ainda não descobrimos. }\end{array}$ &,- 074 &, 158 & ,784 \\
\hline
\end{tabular}


Escala de Hesitação à Vacina (VHS):

Tabela 21. Estudo de validade da escala de Hesitação à vacina KMO Teste de Bartlett (p - value) $\quad \mathbf{N}^{\mathbf{0}}$ de Dimensões Variância

0.89 $<0.001<20 \%$

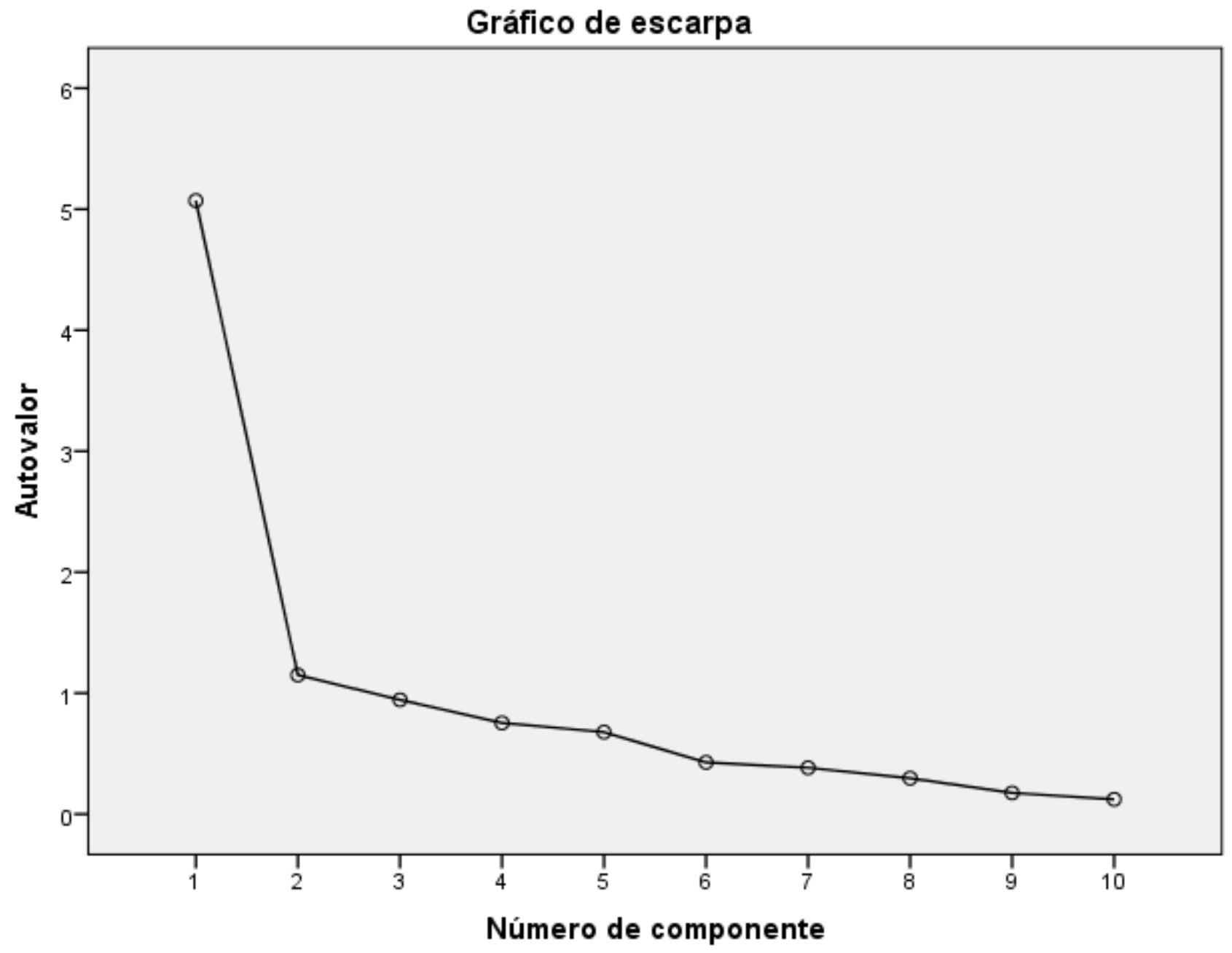

Gráfico 7. Gráfico de Escarpa da Análise Fatorial Exploratória da Escala de Hesitação à vacina 
Tabela 22. Matriz de Componente rotativa da Escala de Hesitação à Vacina

\section{Matriz de componente rotativa ${ }^{a}$}

\begin{tabular}{|c|c|c|}
\hline \multirow{3}{*}{$\begin{array}{l}\text { 7. Vacinar é uma boa maneira de proteger as crianças, adultos e } \\
\text { idosos de doenças. }\end{array}$} & \multicolumn{2}{|c|}{ Componente } \\
\hline & 1 & 2 \\
\hline & ,911 & , 176 \\
\hline $\begin{array}{l}\text { 1. Vacinas para crianças e adultos são importantes para a saúde } \\
\text { de ambos }\end{array}$ & ,892 &, 165 \\
\hline $\begin{array}{l}\text { 3. É importante para a saúde de todas as pessoas em meu bairro } \\
\text { que todos de minha família e parentes sejam vacinados. }\end{array}$ & ,877 & ,013 \\
\hline $\begin{array}{l}\text { 8. Geralmente eu faço para minhas crianças e meus familiares o } \\
\text { que o meu médico e demais profissionais de saúde recomendam } \\
\text { sobre vacinas. }\end{array}$ & ,818 &,- 095 \\
\hline 2. As vacinas são eficazes. & ,802 &,- 129 \\
\hline $\begin{array}{l}\text { 4. Todas as vacinas oferecidas pelos programas de governo às } \\
\text { pessoas de meu bairro são benéficas. }\end{array}$ &, 753 &,- 139 \\
\hline $\begin{array}{l}\text { 6. A informação que recebo sobre as vacinas a partir dos } \\
\text { programas de vacinação é confiável e precisa. }\end{array}$ & ,638 &,- 233 \\
\hline 5. Novas vacinas trazem mais riscos do que benefícios. &,- 493 & ,446 \\
\hline $\begin{array}{l}\text { 9. Eu me preocupo com as reações ou efeitos adversos que as } \\
\text { vacinas provocam. }\end{array}$ &,- 182 &, 825 \\
\hline $\begin{array}{l}\text { 10. Minhas crianças e/ou meus familiares necessitam de vacinas } \\
\text { para as doenças que não são tão comuns ou obrigatórias. }\end{array}$ &, 274 &, 388 \\
\hline
\end{tabular}


Escala de Inteligência Social:

Tabela 23. Estudo de validade da Escala de inteligência social

\begin{tabular}{cccc} 
KMO & Teste de Bartlett $(\mathbf{p}-$ value) & $\mathbf{N}^{\mathbf{0}}$ de Dimensões & Variância \\
\hline $\mathbf{0 . 7 9}$ & $<0.001$ & 5 & $61.86 \%$
\end{tabular}

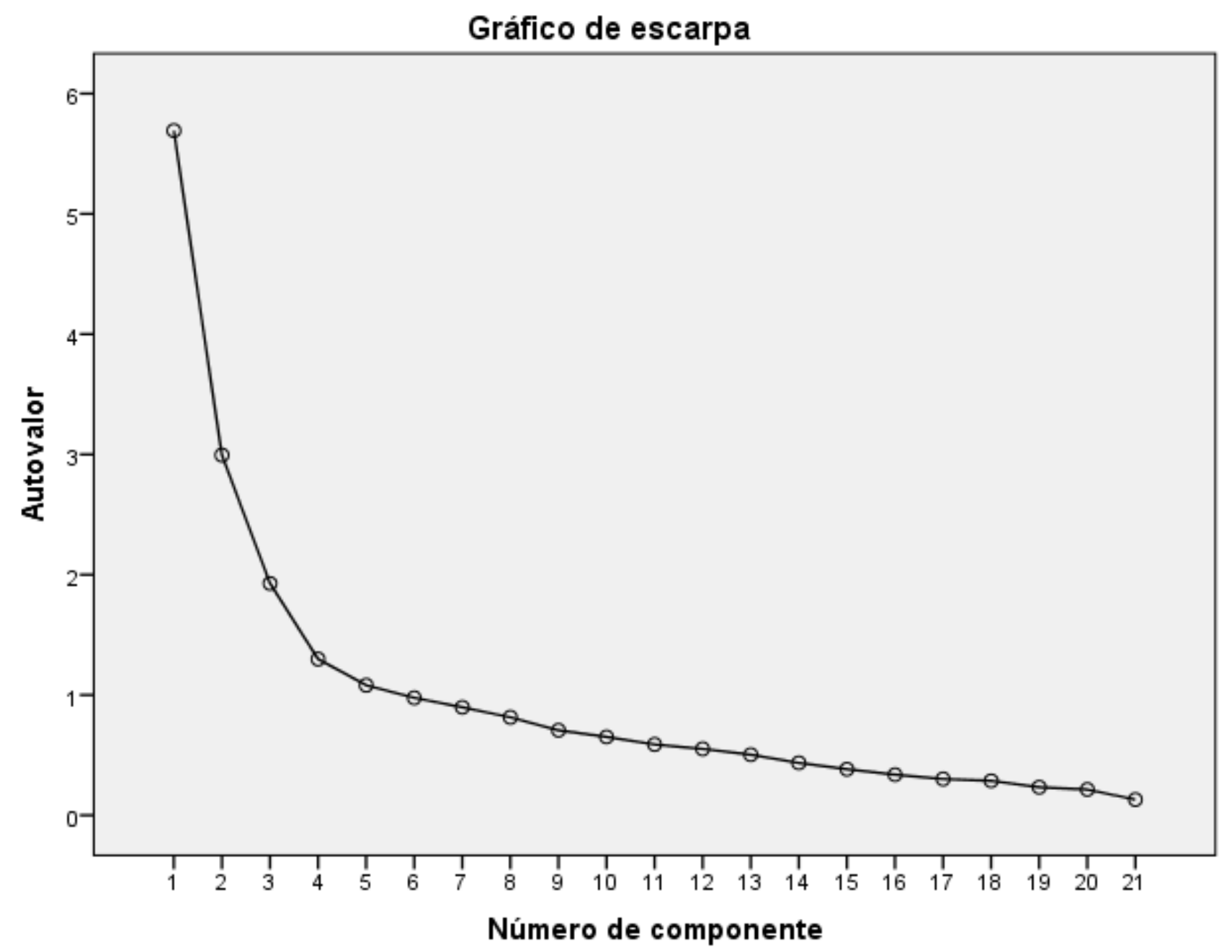

Gráfico 8. Gráfico de Escarpa da Análise Fatorial Exploratória da escala de inteligência social 
Tabela 24. Matriz de Componente rotativa da Escala de Inteligência Social

\section{Matriz de componente rotativa ${ }^{a}$}

\begin{tabular}{|c|c|c|c|c|c|}
\hline & & Com & onente & & \\
\hline & 1 & 2 & 3 & 4 & 5 \\
\hline 18. Sou bom em me relacionar com novas pessoas. & 840 &,- 188 & 189 & ,118 & ,249 \\
\hline $\begin{array}{l}\text { 10. Sou bom em entrar em novas situações e conhecer } \\
\text { pessoas pela primeira vez }\end{array}$ &, 817 &, 017 & 119 &, 121 &, 161 \\
\hline 7. Eu me encaixo facilmente em situações sociais. &, 810 &,- 100 & 106 &,- 064 & ,261 \\
\hline $\begin{array}{l}\text { 4. Costumo me sentir inseguro em relação a pessoas que } \\
\text { não conheço. }\end{array}$ &,- 616 &, 000 & ,032 & ,367 & ,113 \\
\hline $\begin{array}{l}\text { 20. Frequentemente tenho problemas para encontrar bons } \\
\text { tópicos de conversa. }\end{array}$ &,- 526 &, 352 & ,349 &,- 048 &, 186 \\
\hline $\begin{array}{l}\text { 8. Outras pessoas ficam com raiva de mim sem que eu seja } \\
\text { capaz de explicar o porquê. }\end{array}$ &,- 014 & ,765 &, 052 & ,330 &,- 087 \\
\hline 16. Costumo magoar outras pessoas sem perceber. &,- 130 & ,731 & 103 &,- 021 &,- 211 \\
\hline $\begin{array}{l}\text { 11. Parece que as pessoas ficam com raiva ou irritadas } \\
\text { comigo quando digo o que penso. }\end{array}$ &,- 025 & ,694 & 041 &, 295 &,- 190 \\
\hline $\begin{array}{l}\text { 21. Muitas vezes me surpreendo com a reação dos outros } \\
\text { ao que faço. }\end{array}$ &, 070 & ,622 & 079 & ,393 &, 103 \\
\hline $\begin{array}{l}\text { 12. Eu tenho dificuldade em me dar bem com outras } \\
\text { pessoas. }\end{array}$ &,- 440 &, 571 & 021 &, 220 &,- 285 \\
\hline 15. Levo muito tempo para conhecer bem os outros. &,- 277 &, 564 &,- 283 &, 027 &, 173 \\
\hline $\begin{array}{l}\text { 17. Posso prever como os outros reagirão ao meu } \\
\text { comportamento. }\end{array}$ & ,038 &, 025 & ,791 & ,037 &,- 021 \\
\hline 1. Eu posso prever o comportamento de outras pessoas. &, 018 &, 105 & ,726 &,- 233 & ,068 \\
\hline $\begin{array}{l}\text { 14. Muitas vezes consigo entender o que os outros estão } \\
\text { tentando realizar sem que eles necessitem me dizer } \\
\text { qualquer coisa. }\end{array}$ &, 160 &,- 166 & ,633 &, 135 & ,275 \\
\hline $\begin{array}{l}\text { 19. Muitas vezes consigo entender o que os outros } \\
\text { realmente querem dizer através de suas expressões faciais, } \\
\text { linguagem corporal, etc. }\end{array}$ &, 057 &,- 224 & ,621 &, 102 &, 250 \\
\hline 3. Eu sei como minhas ações farão os outros se sentirem. &, 322 &,- 046 & ,608 &,- 112 & ,200 \\
\hline $\begin{array}{l}\text { 5. As pessoas geralmente me surpreendem com o que } \\
\text { fazem. }\end{array}$ &,- 052 &, 183 &, 033 & ,788 &, 035 \\
\hline 13. Acho as pessoas imprevisíveis. & ,046 & ,253 &, 181 & ,683 &,- 134 \\
\hline $\begin{array}{l}\text { 2. Muitas vezes sinto que é difícil entender as escolhas dos } \\
\text { outros. }\end{array}$ &,- 037 &, 173 & 053 & 679 &,- 103 \\
\hline 6. Eu entendo os sentimentos de outras pessoas. & ,293 &,- 084 & ,252 &,- 166 & ,748 \\
\hline 9. Entendo os desejos dos outros. &, 136 &,- 171 & 312 &,- 049 & ,701 \\
\hline
\end{tabular}


Escala de Vulnerabilidade Social:

Tabela 25. Estudo de validade da escala de Vulnerabilidade social KMO Teste de Bartlett (p - value) $\quad \mathbf{N}^{\mathbf{0}}$ de Dimensões Variância

$\begin{array}{llll}\mathbf{0 . 7 8}<0.001 & 4 & 57.71 \%\end{array}$

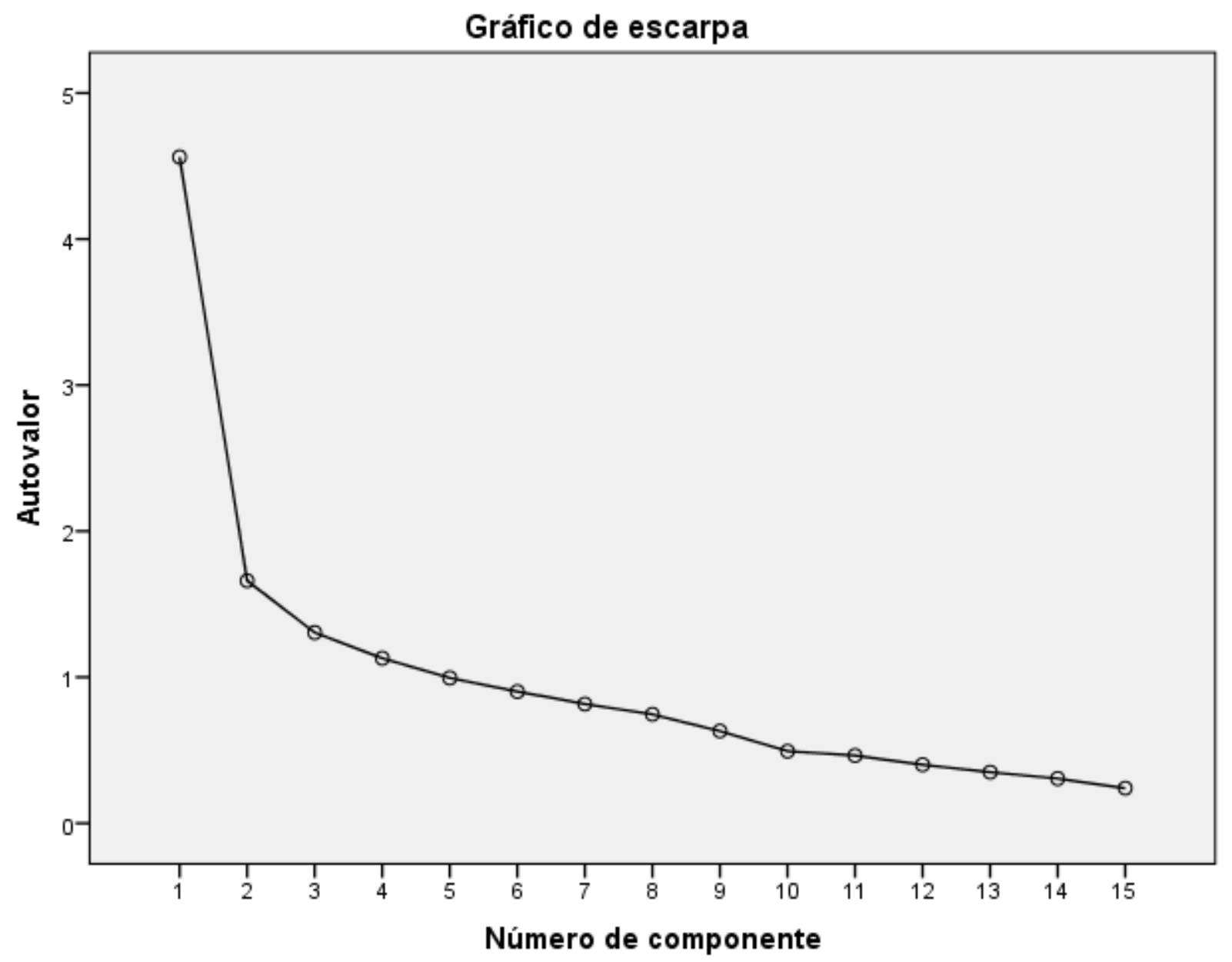

Gráfico 9. Gráfico de Escarpa da Análise Fatorial Exploratória da Escala de Vulnerabilidade social 
Tabela 26. Matriz de Componente rotativa da Escala de Vulnerabilidade Social

\section{Matriz de componente rotativa ${ }^{a}$}

\begin{tabular}{|c|c|c|c|c|}
\hline & \multicolumn{4}{|c|}{ Componente } \\
\hline & 1 & 2 & 3 & 4 \\
\hline 13. Fui enganado(a) por mentiras repetidas. &, 837 & 103 &,- 109 & 075 \\
\hline 14. Eu sou facilmente enganado(a). & ,782 & ,086 &, 127 & 089 \\
\hline 12. Fui enganado repetidamente. & ,683 & 312 &,- 008 & 087 \\
\hline 10. Eu acredito em coisas que são claramente falsas. & 658 & ,351 & 105 & 200 \\
\hline 11. Eu acredito em tudo que leio. & 605 & 081 & 056 & ,467 \\
\hline 1. Fui convencido(a) a comprar itens desnecessários. &, 511 & ,224 & 235 &,- 414 \\
\hline 5. Fui enganado(a) por golpes via e-mail ou correio. & ,108 & ,778 & 054 & 044 \\
\hline $\begin{array}{l}\text { 6. Forneci os detalhes da minha conta bancária a um } \\
\text { estranho. }\end{array}$ & , 126 & ,700 & ,205 &,- 119 \\
\hline 3. Eu apliquei em investimentos duvidosos. & , 158 &, 588 &,- 032 & ,423 \\
\hline 4. Fui influenciado(a) a fazer grandes doações. & , 146 &, 510 &,- 109 & ,465 \\
\hline 2. Paguei por itens que nunca chegaram. & 179 &, 504 & ,134 &,- 168 \\
\hline $\begin{array}{l}\text { 8. Fui convencido(a) a fazer assinaturas de livros, } \\
\text { revistas, jornais e outras obras indesejadas. }\end{array}$ & 021 & ,223 & ,790 &, 149 \\
\hline 7. Fui enganado(a) a pagar as contas de outra pessoa. & ,007 & 053 & 607 &,- 078 \\
\hline 9. Inquestionavelmente, acredito no que me dizem. &, 549 &,- 077 &, 550 & ,295 \\
\hline 15. Creio que os rumores são inquestionáveis. & ,302 &,- 106 & 220 & ,690 \\
\hline
\end{tabular}




\section{Discussão}

A pesquisa analisou fatores cognitivos e comportamentais da hesitação à vacina contra a COVID-19 de uma amostra da população do sudeste do Brasil em dois momentos diferentes da pandemia do novo coronavírus. Os instrumentos utilizados foram escolhidos de acordo com a base teórica sobre o tema de hesitação à vacina e os moderadores psicológicos que possam estar envolvidos neste processo. Assim, algumas escalas e questionamentos sociodemográficos são localizados em um contexto que precede a pandemia da COVID-19, mas que encobre outras epidemias.

As questões foram elaboradas para avaliar e mensurar os níveis de aceitação da vacina contra a COVID-19 em dois momentos da pandemia:

Fase 1 - 22 de julho de 2020 a 23 de outubro de 2020

Neste momento da pesquisa fazia 4 meses que a OMS havia declarado a pandemia. As vacinas ainda estavam em fase de teste-clínico - 166 candidatas ainda em desenvolvimento e 24 sendo testadas em humanos - a taxa de contaminação e de mortalidade do vírus em alta (Ritchie et al., 2021; WHO, 2020a). À data de início da coleta desta fase, o Brasil havia atingido a marca de 92 mil mortes por COVID-19, com uma média de 45.443 casos novos por dia e, ao final do período de coleta - outubro de 2020 -, a curva de mortes estava em queda e chegou a totalizar 154.226 óbitos (Consórcio Nacional de Veículos de Imprensa, 2020a).

Fase 2 - 14 de janeiro de 2021 a 20 de maio de 2021

$\mathrm{Na}$ Fase 2 do estudo as medidas restritivas de quarentena e isolamento social estavam mais flexíveis para os eventos de final de ano, no entanto, janeiro de 2021 havia sido o mês com maior número de mortes desde julho de 2020 , totalizando 224.534 mortes no Brasil até 31 de janeiro (Consórcio Nacional de Veículos de Imprensa, 2021). Em dezembro de 2020 a vacinação contra a COVID-19 já havia sido iniciada em países como Argentina, Estados Unidos da América e Inglaterra. No Brasil o estado de São Paulo foi o primeiro a iniciar a vacinação com profissionais da saúde no dia 17 de janeiro de 2021 e a nível nacional teve início no dia 19 de janeiro de 2021 com as vacinas para uso emergencial, aprovadas pela Agência Nacional de Vigilância Sanitária, são a Coronavac, do Instituto Butantan (ANVISA, 2021a), e a AstraZeneca, 
da Fiocruz (ANVISA, 2021b). Ao final da coleta de dados dessa pesquisa em maio de 2021, o Brasil havia totalizado 454.623 óbitos (Consórcio nacional de Veículos de Imprensa, 2020b).

$\mathrm{Na}$ caracterização da amostra foi possível observar que grande parte dela é composta por $265(73.61 \%)$ mulheres na Fase 1 e 77 (77\%) na Fase 2, com idade média de 35 e 35.61 anos, respectivamente, com ensino superior completo (41.67\% e 42\%) que moram no Estado de São Paulo (52.78\% e 56\%). Além disso, 339 (94.17\%) dos participantes da Fase 1 e 147 (92.45\%) dos da amostra da Fase 2 tomou as vacinas obrigatórias do PNI. Este perfil de participantes pode ser significativo, conforme alguns estudos (Camargo Jr, 2020; Nassaralla et al., 2019), pessoas do gênero feminino e pessoas com nível de escolaridade mais alto tendem a ter um maior índice de aceitação das vacinas devido ao maior acesso à informação. Além disso, conforme Almeida et al. (2020), o Sudeste apresenta uma das coberturas vacinais mais altas do país (89.33\%).

Em ambas fases da pesquisa mais da metade das amostras $(53.33 \%$ e $57 \%$, respectivamente) respondeu "sim" sobre a ação de se vacinar anualmente contra a gripe comum. Desde a fase de desenvolvimento das vacinas contra a COVID-19, sabia-se da probabilidade da vacina contra a Covid-19 precisar ser sazonal (Cuan-Baltazar, 2020; Taylor, 2019). Uma vez que a adesão à vacina deve atingir acima de $70 \%$ da população para diminuir a taxa de contaminação e letalidade (Taylor, 2019; Feemster, 2018), esse dado levantado pela pesquisa pode implicar em uma adesão abaixo da ideal nas doses anuais da vacina contra a COVID-19, podendo prejudicar a manutenção do controle da doença.

Na Fase 1, dos 360 participantes, 171 (47.5\%) não haviam sido infectados pela COVID-19, enquanto apenas 17 participantes (4.72\%) relataram ter contraído a doença e $172(47.78 \%)$ não sabiam. Para a pergunta "21. Considerando a situação atual, informe-nos sobre a probabilidade de você pensar (o quanto atualmente você acredita nisso), que será infectado pela Covid-19 em um futuro próximo de 0 a 10 (sendo 0 muito baixa e 10 muito alta)", os participantes relataram uma média de 6.47 para a chance de contaminação.

Segundo Taylor (2019), interpretações sobre o próprio estado de saúde e a probabilidade que um indivíduo pensa que tem em se infectar com alguma doença 
infecciosa são processos relacionados com a memória e lembranças de experiências anteriores. Crenças com base em falsas informações sobre o modo de contágio de determinada doença, pode aumentar essa percepção de contágio (Taylor, 2019). É importante lembrar que, à época da Fase 1, não havia materiais ou peças publicitárias governamentais sobre modos de contaminação e prevenção ao COVID-19 (Gramacho \& Turgeon, 2021), o que pode ter influenciado na média do quanto a amostra acreditava poder ser infectada.

De acordo com a Teoria do Comportamento Planejado (TPB) e o Modelo de Crenças à Saúde (HBM) (Park et al., 2020), atitudes que se propõem a mitigar o risco de contaminação à doença - uso de máscaras, higiene das mãos e isolamento social - são realizadas de modo individual quando há percepção do risco. Na questão “25. Geralmente, quantas vezes você sai de casa por dia?", considerando-se que eram os primeiros meses da pandemia e julho tendo sido o mais letal de 2020 no Brasil (Ritchie et al., 2020), os participantes saíam, em média, 1.03 vezes de casa por dia, o que pode indicar uma boa taxa de manutenção do isolamento social desta amostra.

Já na Fase 2, dos 100 participantes, 18 (18\%) relataram que foram infectados, 60 (60\%) não foram e 22 participantes (22\%) não sabiam. Referente à questão "28. Considerando a situação atual, informe-nos sobre a probabilidade de você pensar (o quanto atualmente você acredita nisso), que será infectado pela Covid-19 em um futuro próximo de 0 a 10 (sendo 0 muito baixa e 10 muito alta)", a média dessa amostra foi de 5.41 - pouco abaixo da média da Fase 1. Neste período, 32 participantes (32\%) responderam "Não” à questão "32. Mesmo após 10 meses de pandemia, você ainda se mantém em isolamento social?”. Da mesma forma que a percepção do risco influencia na crença de infecção (Taylor, 2019; Park et al., 2020), pode ocorrer também a fase de habituação ao risco e uma diminuição significativa na percepção de letalidade da doença, no medo de se infectar e, consequentemente, redução dos comportamentos preventivos (Taylor, 2019; Slovic et al., 2004).

Na questão “20. Você irá se vacinar contra a COVID-19?” da Fase 2, 98 (98\%) dos participantes responderam "Sim”. Já na questão "21. A origem da vacina (país e/ou laboratório) contra a COVID-19 tem influência na sua decisão para se vacinar?" 20 (20\%) dos participantes responderam "Sim". Apesar da maioria (80\%) ter respondido "Não", segundo estudo de Gramacho \& Turgeon (2021), 88.3\% dos brasileiros possuem 
a intenção de se vacinar contra a covid-19 quando nenhum país é citado como desenvolvedor da mesma.

Neste mesmo estudo quando é citado o país de origem da vacina principalmente China e Rússia - 67\% e $72.6 \%$ dos brasileiros relatam uma menor intenção à vacinação (Gramacho \& Turgeon, 2021). Vários estudos consideram que a aceitação à vacina é moderada pelas preferências políticas (Gramacho \& Turgeon, 2021; Cerda \& García, 2021; Urrunaga-Pastor et al., 2021; WHO, 2013). As respostas das pessoas ao COVID-19 são moldadas de acordo com a opinião de seus respectivos líderes e são um reflexo de suas preferências políticas (Jetten et al., 2020).

\subsection{Fatores cognitivos, comportamentais e personalidade nas atitudes antivacina}

O processo de tomada de decisão de tomar ou não uma vacina passa por questões pessoais, culturais e até políticas (Taylor, 2019; Shapiro et al., 2017; WHO, 2013). A aderência às teorias conspiratórias e ao movimento antivacina, de acordo com Taylor (2019), pode estar intimamente relacionada com pensamentos mágicos, traços de personalidade narcisista, alta percepção de vulnerabilidade à doença, pouco acesso às informações confiáveis, ingenuidade e aceitação de falsos tratamentos em detrimento de comprovações científicas.

Na Fase 1 do estudo o INP-16 foi aplicado em 201 participantes. A média total de escore foi 7.41, e, ao contrário do que é encontrado na literatura sobre o fator de personalidade (Taylor, 2019; Ames et al., 2005), não houve grande variação na frequência dos escores entre gênero. A média feminina (7.32) manteve-se semelhante à masculina (7.70) e ambas não apresentaram estatisticamente significativos para a correspondência de traços de personalidade narcisista.

Já na escala de auto-relato de credulidade (Teunisse et al., 2020), também aplicada à 201 participantes da Fase 1, foi possível observar uma diferença de gênero, a média de escores para as mulheres (33.23) foi maior que a média masculina (31.32). Essas médias indicam um nível médio de credulidade na amostra estudada e a diferença de gênero corresponde ao estudo de (Teunisse et al., 2020), que apresenta a amostra feminina com níveis de maiores de ingenuidade. 
Quando avaliamos o nível de aderência às teorias conspiratórias antivacina (Shapiro et al., 2016), na Fase 1 do estudo encontramos resultados que indicam um nível baixo de aderência, tanto na média feminina (13.52), quanto na masculina (11.88). No entanto, houve uma diferença significativa na diferença de gênero, apontando a amostra feminina como mais provável a aderir às teorias. Já no fator de atitudes antivacina (Martin \& Petrie, 2017), ainda na Fase 1, além de ter apresentado a média geral de escores (26.92) que indica um nível médio de atitudes antivacina. A média de escore feminina (27.6) também se mostrou significativamente maior que a masculina (24.82).

No geral, sugere-se que as teorias conspiratórias atraem pessoas que buscam significados para questões pessoais ou não possuem capacidade cognitiva para encontrar as respostas de maneira racional, o que pode levar à crença de que possuem informações raras que outras pessoas não têm (Camargo Jr, 2020; Taylor, 2019; Pummerer et al., 2020; Biddlestone et al., 2020). Assim, entende-se que os níveis de credulidade e a existência de traços de personalidade narcisista poderiam se relacionar positivamente com a adesão às teorias antivacina e a atitudes antivacina (Malik et al., 2020; Taylor, 2019; Succi, 2017). No movimento antivacina - e até na hesitação à vacina - a literatura aponta que o grupo mais afetado são mulheres e, geralmente grávidas (Skjefte, 2021; Malik et al., 2020).

Os resultados os escores dos moderadores cognitivos, comportamentais e de personalidade da Fase 1 desta pesquisa corroboram com esta relação que a literatura apresenta, pois, a amostra feminina apresentou scores maiores em todos os moderadores, com exceção do fator de personalidade narcisista, o que pode indicar uma tendência maior às atitudes antivacina ou de hesitação. No entanto, não indica médias relevantes para caracterizar esta amostra como antivacina.

As escalas de Aderência às Teorias Conspiratórias Antivacina (Shapiro et al., 2016) e a Escala de Atitudes Antivacinação (Martin \& Petrie, 2017) apresentaram uma correlação significativa ( $\mathrm{r}$ de Pearson $=0.468 ; \mathrm{p}<0,01)$. No entanto, nem a Escalade Auto-Relato de Credulidade, nem o INP-16 apresentaram níveis de correlação significativos com a Escala de Aderencia às Teorias Conspiratórias Antivacina nem com a Escala de Atitudes Antivacina, não corroborando com outros estudos (Malik et al., 2020; Taylor, 2019; Succi, 2018). 
É importante ressaltar que na Fase 1 da pesquisa, a vacina contra a Covid-19 ainda estava em fase de teste. As ideias antivacina começaram a ganhar força no país por meio das redes sociais e de opiniões do governo (Gramacho \& Turgeon, 2021) ao final desta Fase da pesquisa. Em setembro de 2020 a Secretaria Especial de Comunicação Social (SECOM) (Reuters, 2020) divulgou em suas redes sociais oficiais uma peca publicitária com frase que dizia "ninguém pode obrigar ninguém a tomar a vacina", como uma defesa à liberdade do povo brasileiro. Este tipo de discurso é padrão dos adeptos ao movimento antivacina e gera grande influência à população ter atitudes e comportamentos similares. A literatura também mostra que o fato de alguma personalidade importante acreditar, fazer parte ou divulgar determinado movimento, pode levar a parte da população de um país a aderir a este movimento, utilizando o prestígio e fama da personalidade como justificativa e confirmação (Camargo Jr., 2020; Vasconcellos-Silva \& Castiel, 2020).

$\mathrm{Na}$ Fase 2 da pesquisa, as escalas de Aderência às Teorias Conspiratórias Antivacina (Shapiro et al., 2016) e a Escala de Atitudes Antivacinação (Martin \& Petrie, 2017) foram reaplicadas. Na Escala de Aderência às Teorias Conspiratórias, a média de escore da amostra total foi de 12.26. Não teve diferença de gênero significativas, sendo a média para amostra feminina (12.32) próxima da masculina (12.04). Em relação à Escala de Atitudes Antivacina, a média da amostra total (26.73), o que indica um nível médio de adesão às atitudes antivacinas. Não foi observada diferenças significativas entre a média feminina (26.93) e masculina (26.04).

Apesar da média de escores da Escala de Aderência às Teorias Conspiratórias Antivacina ter sido maior na Fase 1 do que na Fase 2, ainda assim não são pontuações que indiquem um nível alto de aderência às teorias sobre as vacinas. $\mathrm{O}$ fato da coleta da Fase 2 ter ocorrido em um dos meses mais letais da pandemia da covid-19 no Brasil, concomitantemente com o início da vacinação, pode ter influenciado na queda da média dos escores dessas escalas.

\subsection{Hesitação à vacina}

Em um levantamento feito pelo Datafolha em 14 de dezembro de 2020, observou-se que a maior taxa de hesitação à vacina encontra-se na faixa etária entre 25 a 34 anos (30\%), entre quem está vivendo a vida normalmente durante a pandemia (37\%) e entres os apoiadores do atual Presidente da República (30\%) (Datafolha, 2020a). A 
divulgação destes dados pode demonstrar a influência que uma figura de poder - com falas sobre falsas consequências e prejuízos que as vacinas causam - pode ter sobre uma população e inferir graves consequências ao controle da pandemia da Covid-19.

No dia 7 de novembro de 2020 o Datafolha (2020b) divulgou dados sobre a intenção a adesão à vacina contra a Covid-19. Nestes dados, 46\% dos entrevistados alegaram que não concordam com a obrigatoriedade da vacina contra a Covid-19 e cerca de $39 \%$ dos respondentes alegaram que não tomariam uma vacina desenvolvida pela China, a Coronavac (Datafolha, 2020b). Um mês após a divulgação destes dados, a DataFolha fez novo levantamento divulgado no dia 14 de dezembro de 2020. Neste novo levantamento a intenção de vacinação dos brasileiros contra o coronavírus caiu de $89 \%$ para $73 \%$ (Datafolha, 2020a).

A obrigatoriedade à vacinação tem por objetivo evitar a baixa adesão à campanha vacinal de uma doença infecciosa que está em curso e não tão bem controlada (WHO, 2013). Historicamente, no entanto, é uma estratégia coercitiva que colabora para o movimento de hesitação à vacina (Dubé et al., 2017). É conhecido - e amplamente discutido por órgão especializados - que a negação e a hesitação da vacina têm como fator desconfiança em órgãos superiores e em especialistas (WHO, 2013; Larson et al., 2014; Camargo Jr, 2020). No entanto, quando o próprio governo faz parte desse movimento, acaba por "validar" a desconfiança em órgãos como a OMS e em infectologistas, ocasionando em uma baixa adesão às medidas protetivas e, consequentemente, à vacinação (Cuan-Baltazar et al., 2020; National Academies of Science, 2020).

Segundo estudo de Urrunaga-Pastor et al., (2021), um dos principais fatores que contribuem para a hesitação à vacina em países da América do Sul é o medo de reações adversas. A decisão de uma pessoa de ser vacinada diminui não apenas seu próprio risco de infecção, mas também reduz o risco para as pessoas com quem interage (Taylor, 2019). “Algumas pessoas se preocupam com a segurança da vacina, especialmente devido à velocidade sem precedentes com que as vacinas COVID-19 avançaram no processo de desenvolvimento" (Kahn et al., 2020).

Na Fase 1 da pesquisa, 159 participantes responderam à Escala de Hesitação à Vacina (Shapiro et al., 2018). A média do escore da amostra total (40.35) não apresentou variação das médias da amostra feminina (40.27) nem da masculina (40.58). 
Estes escores indicam um nível médio de hesitação à vacina. Na Fase 2, a média de escores da amostra total (41.52) e das amostras feminina (41.77) e masculina (40.65) apresentaram um pequeno aumento em relação às médias da Fase 1.

Pode-se dizer que, nas duas fases da pesquisa - e da pandemia - o nível de hesitação à vacina permaneceu o mesmo. Isso pode ser explicado pela constância das informações falsas sobre as vacinas contra a covid-19 e seus efeitos adversos divulgadas pelo Presidente da República. Apesar dos altos níveis de percepção à doença, o que corrobora com a literatura (Grmacho \& Turgeon, 2021; Urrunaga-Pastor et al., 2021) de que a percepção da letalidade e gravidade da doença, não tem grandes influências na intenção de se vacinar, no entanto, provoca um nível significativo de hesitação à vacina por medo dos possíveis - e às vezes desconhecidos - efeitos adversos da vacina.

A hesitação a vacina da Covid-19 pode trazer sérios problemas para o controle da pandemia. Uma das maneiras de adquirir a imunidade de rebanho - proteção indireta da doença em questão que ocorre quando um grande número de pessoas se torna imune - é com a vacinação. Segundo Taylor (2020) tem sido proposto uma média de cobertura vacinal de $80 \%$ da população para se alcançar essa imunidade.

Os dados obtidos da Escala de hesitação à Vacina não correspondem às diferenças apontadas pelos autores (Shapiro et al., 2018) em relação ao gênero, pois não encontramos diferenças significativas entre as médias de escores masculinas e femininas. No entanto, os autores (Shapiro et al., 2018) apontam que uma amostra com ensino superior completo e uma idade média de 35 anos tende a apresentar escores que correspondem a um nível médio de hesitação à vacina, o que corrobora com nossas amostras que se encontram dentro destes moderadores sociodemográficos.

\subsection{Percepção à doença infeciosa}

A percepção do risco de uma doença compreende a percepção da suscetibilidade de risco e sua severidade e pode ser também o ponto chave para o engajamento individual em comportamentos preventivos (Park et al., 2020). A preocupação com a segurança das vacinas pode ser alta quando os programas de vacinação para determinada doença foram bem sucedidos, fazendo os indivíduos terem uma percepção maior sobre o risco da vacina (Dubé et al., 2017; WHO, 2013). Por outro lado, se a percepção ao risco da doença for alta, indivíduos podem decidir se vacinar, 
independente de suas preocupações pessoais com as vacinas disponíveis (Karlsson et al., 2021).

Na Fase 1 desta pesquisa, os respondentes dos questionários do Módulo 7 (n = 201) apresentaram na Escala de Percepção à Vulnerabilidade à Doença Infecciosa uma medida total de escore de 67, indicando um alto nível de percepção. Neste mesmo módulo foi observada uma diferença relevante entre a média feminina (67.87) e masculina (64.4).

Os participantes que responderam aos questionários do Módulo $8(\mathrm{n}=159)$ mostraram uma média total do escore (68.97) um pouco mais alta que a do módulo 7. Entre esses participantes observou-se também uma diferença entre as médias femininas (68.25) e masculinas (70.77). Já na Fase 2 do estudo, a média de escore da amostra total (70.20) se mostrou maior que as médias totais anteriores. Em relação à diferença em frequência de gênero, a média feminina (71.16) se mostrou maior que a total e a masculina (66.95).

Em um estudo feito por Karlsson et al. (2021), mostrou-se que os indivíduos que tivessem uma percepção do risco da COVID-19 maior, teriam maiores intenções de se vacinarem. Alguns estudos sugerem que a percepção ao risco à doença seria maior durante o cumprimento de medidas de isolamento social (Caserotti et al., 20212; Karlsson et al., 2021; Park et al., 2020). Estes estudos corroboram com os dados desta pesquisa, tanto na Fase 1 quanto na Fase 2.

Na Fase 1, o país encontrava-se tentando flexibilizar algumas restrições, mas a população da amostra desta pesquisa ainda cumpria o isolamento social. Além disso, a amostra total da Fase 1 apresentou uma média elevada (6.47) ao serem questionados no quanto acreditavam que poderiam se infectar com o Corona vírus, o que pode estar relacionado aos altos escores de Percepção à Vulnerabilidade à Doença.

Enquanto isso, a Fase 2 apresentou os maiores escores de percepção à vulnerabilidade à doença em relação à Fase 1. Neste período, 68\% da amostra relatou ainda cumprir as medidas de isolamento social, apesar de diversas cidades estarem flexibilizadas, o que pode explicar a média menor (5.41) em relação às chances de se infectarem com o vírus. À época da Fase 2 desta pesquisa, o Brasil vivia seus meses 
mais letais em relação à COVID-19 desde março de 2020 e a intenção de vacinação contra a covid-19 nessa fase se mostrava em 98\%. Esses dados, além de justificarem os altos níveis de percepção e os baixos níveis de hesitação à vacina encontrados neste, ainda são corroborados por vários estudos (Caserotti et al., 2021; Karlsson et al., 2021; Park et al., 2020).

Vários estudos (Caserotti et al., 20212; Karlsson et al., 2021; Park et al., 2020; Duncan et al., 2009) apontam uma diferença de gênero na percepção à vulnerabilidade à doença, na qual o gênero feminino teria uma maior percepção, por geralmente serem as mulheres as encarregadas aos cuidados com a saúde da família. Com exceção dos respondentes do Módulo 8 da Fase 1, os dados de frequência de gênero do modulo 7 da Fase 1 e dos respondentes da. Fase 2 são corroborados por esses dados (Duncan et al, 2009).

\subsection{Inteligência social}

O construto de inteligência social, que se divide em componentes cognitivos e comportamentais é, em definição, a habilidade de compreender e lidar com indivíduos, ou seja, agir de maneira inteligente e funcional nas relações humanas (Thorndike, 1920, citado por Kosmitzki \& John, 1993). Os fatores da inteligência social podem ser divididos em manipulação social; habilidades sociais; empatia social; e extroversão; adaptabilidade social (Silvera et al., 2001). No contexto da pandemia da COVID-19 essas habilidades podem ser interpretadas no modo como o indivíduo percebe a real gravidade da doença e em como o contexto pode - e tem afetado - a população em geral (Karlsson et al., 2021; Jetten et al., 2020).

Durante a Fase 1 da pesquisa, os participantes que responderam aos instrumentos do Módulo $8(\mathrm{n}=159)$ apresentaram na Escala de Inteligência Social (Silvera et al., 2001) uma média total de escore de 95.37, indicando um nível alto de inteligência social. A média feminina (96.84) apresentou um escore maior que a média da amostra masculina (91.64). No estudo de validação da escala, os autores (Silvera et al., 2001) não encontraram diferenças significativas de gênero.

A escala possui as sub escalas de consciência social (CS), processamento de informação social (PS) e habilidades sociais (HS) - a amostra total apresentou escores 
que indicam níveis altos de cada uma, CS (31.47), PS (30.30) e HS (33.59). As médias dos escores das sub escalas apresentaram pouca diferença entre a amostra feminina (CS 31.87; PS 30.85; HS 34.10) e a masculina (CS 30.46; PS 28.88; HS 32.28). Essa baixa diferença de gênero encontrada neste construto corrobora com os estudos prévios dos autores da escala (Silvera et al., 2001) e em estudos mais recentes sobre a inteligência social (Habib et al., 2013).

Os escores totais da escala (95.37) e da sub escala de processamento de informação social (30.30), podem ajudar a explicar - dentro desta amostra - os altos níveis de isolamento social (68\% da amostra da Fase 2), mesmo com as flexibilizações sendo feitas, e os altos índices de percepção à doença infecciosa que esta amostra apresentou na Fase 1 do estudo (67 e. 68.25). A percepção da real gravidade da pandemia e da alta probabilidade de infecção pelo coronavírus nas duas fases da pesquisa, são fatores que, possivelmente, podem ser influenciados por baixos níveis de narcisismo e uma alta percepção da realidade social, indo além da própria comunidade (Jetten et al., 2020; Taylor, 2019; Silvera et al., 2001).

\subsection{O lugar do Brasil na pandemia da covid-19}

Nesta pesquisa não foram encontrados níveis altos de hesitação à vacina ou de tendências a comportamentos negacionistas. Estes resultados corroboram com outro estudo realizado em 2021 pelos autores Urrunaga-Pastor et al. (2021). Neste estudo realizado em países da América Latina, $83.1 \%$ da amostra brasileira declarou ter intenção de se vacinar contra a COVID-19. No entanto, os autores apontaram que, da mesma forma que a intenção de se vacinar no Brasil e na América Latina era alta, o medo de efeitos adversos. Causados pela vacina da COVID-19 foi relatado por $68.2 \%$ da amostra brasileira (Urrunaga-Pastor et al., 2021).

Diversos estudos têm mostrado que, quando a indicação para se vacinar vem de especialistas da saúde ou órgãos especializados, a intenção a se vacinar é maior do que quando a indicação vem de políticos ou do governo (Urrunaga-Pastor et al., 2021; Cerda \& García, 2021; Malik et al., 2020). A situação da pandemia da COVID-19 na Fase 2 deste estudo era significativamente pior do que a Fase 1 em relação à lotação dos hospitais, à falta de insumos e de vacinas (já disponíveis em outros países desde 
dezembro de 2020) e ao número de óbitos e taxa de contaminação do vírus (WHO, 2020b; Consórcio Nacional de Veículos de Imprensa, 2021; ANVISA, 2021a, 2021b).

Como mostraram os resultados obtidos, a alta percepção da gravidade da doença superou o medo à vacina na população desta amostra. A literatura traz que a provável relação dos governos às vacinas - seja indicando ou contraindicando as mesmas - pode gerar um maior nível de hesitação na população (Urrunaga-Pastor et al., 2021; Cerda \& García, 2021; Malik et al., 2020; Taylor, 2019). No entanto, tem-se levantado a hipótese de que durante a pandemia no Brasil a opinião do governo sobre a vacina pode apresentar maior influência na intenção de se vacinar do que a explicação de especialistas (Gramacho \& Turgeon, 2021; Camargo Jr, 2020; Vasconcellos-Silva, 2020).

\subsection{Análise Fatorial Exploratória e Correlações entre fatores}

Foram feitas as análises de correlação de Pearson entre escalas que, de acordo com a literatura (Camargo Jr, 2020; Taylor, 2019; Shapiro et al., 2018, 2016; Duncan et al., 2009; WHO, 2013), possuem fatores que podem apresentar alguma correlação significativa entre si, dentro do contexto do problema da hesitação à vacina.

As escalas Aderência às Teorias Conspiratórias e Atitudes Antivacina apresentaram uma tendência a correlação, com $r=0.468$ para $p<0.01$. A correlação apresentada, apesar de baixa devido ao tamanho da amostra, é direta e corrobora com a teoria de que há uma tendência a apresentar atitudes antivacina - ou hesitantes à vacina - à medida que se acredita em teorias conspiratórias e falsas sobre as mesmas (WHO, 2013; Camargo Jr, 2020).

Entre a Escala de Hesitação à Vacina e à Escala de Percepção à Vulnerabilidade à Doença Infecciosa apresentaram uma correlação baixa, mas significativa $(r=0.221 ; \mathrm{p}$ $<0.01)$. Embora tenha sido significativo, houve tendência devido ao tamanho da amostra. As demais análises de correlação feitas entre o Inventário de Personalidade Narcisista (INP-16) e às escalas Aderência às Teorias Conspiratórias e Atitudes Antivacina não apresentaram correlações significativas, o que não vai ao encontro do que é proposto na literatura (Taylor, 2020). Acredita-se que em uma amostra maior do que a alcançada nesta pesquisa, as análises apresentariam resultados mais significativos.

Para verificar a validade da estrutura interna das escalas tipo Likert utilizadas na pesquisa (Escala de Auto-Relato de Credulidade; Escala de Percepção à 
Vulnerabilidade à Doença Infecciosa; Escala de Aderência às Teorias Conspiratórias; Escala de Atitudes Antivacina; Escala de Hesitação à Vacina, Escala de Vulnerabilidade Social; e Escala de Inteligência Social) foi realizada uma Análise Fatorial Exploratória, pois foram traduzidas ao português e algumas tiveram alguns itens adaptados ao cenário da pandemia. Todas as escalas apresentaram boa fidedignidade em todos os seus itens.

A Escala de Auto-Relato de Credulidade (George et al., 2020), com idioma original no inglês foi traduzida para o português. No estudo original para a escala de 12 itens, foram encontrados 2 fatores na AFE (Teunisse et al., 2020). Na AFE feita com a escala traduzida, também resultaram 2 dimensões, com variância total de $60.20 \%$.

No estudo da Escala de Percepção à Vulnerabilidade à Doença, analisaram a versão da escala com 15 itens, no idioma original - inglês - e encontraram 2 dimensões com variância total de 46.3\% (Duncan et al., 2009). Para esta pesquisa, a escala foi traduzida para o português e os itens não foram alterados. Na AFE realizada, resultaram em 3 dimensões significativas com variância de. 50.57\% para a escala.

$\mathrm{Na}$ Escala de Aderência às Teorias Conspiratórias os autores Shapiro et al. (2016) analisaram a estrutura interna da escala com uma dimensão que contaria com $68.37 \%$ da variância total. Para este estudo foi adicionado o item "8. A vacina da gripe permite ao governo monitorar os idosos por meio da implantação de pequenos dispositivos de rastreamento", o que apresentou a escala com duas dimensões (sendo mias significativa apenas no item 5, como mostra a Tabela 18) e com $71.29 \%$ da variância total.

Ao analisar a Escala de Atitudes Antivacina, os autores concluíram que a versão de 12 itens era a que melhor possuía consistência interna, com 4 dimensões (Martin et al., 2017). Para esta pesquisa, foi utilizada a versão com 12 itens traduzida para o português e a partir da AFE, foram encontradas 3 dimensões com $70.93 \%$ para variância. A diferença entre as dimensões pode ter se dado devido ao número da amostra dessa pesquisa, que foi menor que a do estudo original.

A Escala de Hesitação à Vacina foi validada originalmente em inglês e contendo 10 itens. Na AFE do estudo conduzido pelos autores da escala, avaliaram a escala com 2 dimensões que validam os constructos da escala, com variância total de $54.81 \%$ (Shapiro et al., 2018). Para esta pesquisa apenas traduzimos a escala para o português. $\mathrm{Na}$ AFE foram encontradas 2 dimensões e com variância total de $62.20 \%$.

Já a Escala de Inteligência Social, originalmente no idioma norueguês, considerou 3 dimensões significativas na AFE, com variância total de 30\% (Silvera et 
al., 2001). Nesta pesquisa, utilizou-se a versão em inglês da escala para traduzir ao português. Na AFE deste estudo, foram encontradas 5 dimensões com variância de $61.86 \%$, os componentes 1,2 e 3 são mais significativos do que os componentes 4 e 5 , como mostra a Tabela 24.

A Escala de Vulnerabilidade Social foi validada na versão com 15 itens em inglês. No estudo de validade do constructo, os autores encontraram 2 fatores com variância total de 53.44\% (Pinsker et al., 2011). Nesta pesquisa, foram encontradas 4 dimensões com variância total de 57.71\%, mas com apenas os componentes 1 e 2 mais significativos, como mostrou a Tabela 26. 


\section{Conclusão}

No contexto de uma pandemia global, na qual não se sabe exatamente os efeitos da doença e não existe nenhum remédio ou vacina disponíveis, é esperado que em um primeiro momento o medo seja o sentimento predominante e as pessoas passem a adotar comportamentos preventivos. Saber o que fazer - ou até mesmo compreender a gravidade real da situação - exige certo nível de percepção à própria vulnerabilidade à doença e alta percepção de que provavelmente existem pessoas que são mais vulneráveis e dependem do cuidado de terceiros para evitar a contaminação.

A vacinação é historicamente conhecida por erradicar ou prevenir a morte de doenças que já são evitáveis. Vacinas novas podem causar medo de efeitos adversos e com isso possibilitar a hesitação à vacina em algum nível, o que pode ser corroborado nesta amostra. A pandemia da COVID-19, em 2020, tratava-se de uma doença com letalidade, consequências e sintomas pouco conhecidos, além de não possuir tratamento eficaz ou vacina.

O conhecimento popular de que vacinas demoram muitos anos para serem aprovadas e liberadas para a população entra em conflito no cenário pandêmico, no qual cientistas do mundo inteiro - incluindo do Brasil com a Butanvac (Butantan, 2021) conseguem produzir uma vacina eficaz contra o novo coronavírus em menos de um ano. Esta velocidade pode, consequentemente, provocar medo e desconfiança na população em relação à vacina e a propagação de notícias falsas. $\mathrm{O}$ que foi observado na amostra pelos níveis médios de hesitação à vacina, mas altos índices de intenção à vacinação pela população da amostra.

Neste contexto fatores como medo, percepção à doença infecciosa e ao cenário social, capacidade de pensamento crítico para diferenciar informações sensacionalistas de verdadeiras e confiança em órgãos especializados podem ser definitivos para indicar a intenção de vacinar ou não de uma população, como foi demonstrado nos resultados deste estudo tanto na Fase 1 quanto na Fase 2. É possível levantar a hipótese de que, o fato da região sudeste do Brasil mantinha altos níveis de cobertura vacinal nos últimos anos, pode ter influência na intenção de se vacinar contra a COVID-19 e nos baixos níveis de atitudes antivacina. 
A hesitação à vacina e um constructo complexo e muito amplo, então fatores culturais, influências políticas e afetivas - que não foram avaliados profundamente nesta população - podem influenciar na tomada de decisão à vacina.

Não foi possível verificar se nível educacional e traços de personalidade influenciam na intenção de ser vacinar, pois a amostra deste estudo se mostrou homogênea no nível de escolaridade. É importante ressaltar que a amostra desta pesquisa não representa uma amostra a nível nacional, não permitindo extrapolar estes dados para populações diferentes da caracterizada neste estudo.

A falta de acesso e entendimento sobre cuidados preventivos com a saúde e a natureza de doenças infeciosas pode deixar a população em um estado de extrema vulnerabilidade e de desinformação. Novos estudos serão necessários para aprofundar estes fatores que permeiam a hesitação à vacina, a percepção à doença e ao contexto da comunidade em outras populações de diferentes níveis socioeonômicos e educacionais para compreender este fenômeno que é recente e pode impactar na vacinação contra a COVID-19 para a contenção desta e de futuras pandemias ou epidemias. As mensagens de saúde pública precisam ser adaptadas para se adequar ao grupo pretendido: reforço daqueles que aceitam totalmente a vacina, respostas para aqueles que estão hesitantes e abordagens muito diferentes para aqueles que recusam completamente todas as vacinas. 


\section{Referências}

Ajzen, I. (2002a). Perceived behavioral control, self-efficacy, locus of control, and the theory of planned behavior. Journal of Applied Social Psychology, 32, 665-683.

https://doi.org/10.1111/j.1559-1816.2002.tb00236.x

Ajzen, I. (2002b). Residual effects of past on later behavior: Habituation and reasoned action perspectives. Personality and Social Psychology Review, 6, 107-122. https://doi.org/10.1207/S15327957PSPR0602_02

Almeida, C.M.S., Souza, L.G.D., Coelho, G.N., Almeida, K.C. (2020). Correlação entre o aumento da incidência de sarampo e a diminuição da cobertura vacinal dos últimos 10 anos no Brasil. Brazilian Journal of Health Review, 3(1). https://doi.org/10.34119/bjhrv3n1-031

Ames, D. R., Rose, P., \& Anderson, C. P. (2006). The NPI-16 as a short measure of narcissism. Journal of Research in Personality, 40(4), 440450. https://doi.org/10.1016/j.jrp.2005.03.002

ANVISA - Agência Nacional de Vigilância Sanitária. (2021a) Andamento da análise das vacinas na ANVISA. [acesso em 20 jan 2021]. Disponível em: https://www.gov.br/anvisa/pt-br/assuntos/noticias-anvisa/2021/nota-uso-emergencialbutantan.

ANVISA - Agência Nacional de Vigilância Sanitária. (2021b) Andamento da análise das vacinas na ANVISA. [acesso em 20 jan 2021]. Disponível em: https://www.gov.br/anvisa/pt-br/assuntos/noticias-anvisa/2021/nota-uso-emergencialfiocruzBeltrão, R. P. L., Mouta, A. A. N., Silva, N. S., Oliveira, J. E. N., BeltrãoI. T., Beltrão. C. M. F., Fontenele, S. M., \& da Silva, A. C. B. (2020). Perigo do movimento antivacina: análise epidemio-literária do movimento antivacinação no Brasil. Revista Eletrônica Acervo Saúde, 12(6), e3088. https://doi.org/10.25248/reas.e3088.2020

BRASIL, Ministério da Saúde. (2019). Situação do Sarampo no Brasil -. Brasília, DF.

BRASIL, Ministério da Saúde. (2013). Programa Nacional de Imunizações (PNI): 40 anos. - Secretaria de Vigilância em Saúde, Departamento de Vigilância Epidemiológica.

Biddlestone, M., Green, R., \& Douglas, K. M. (2020). Cultural orientation, power, belief in conspiracy theories, and intentions to reduce the spread of COVID-19. The British journal of social psychology, 59(3), 663-673. https://doi.org/10.1111/bjso.12397 
Camargo Jr, KR. (2020). Lá vamos nós outra vez: a reemergência do ativismo antivacina na Internet. Cadernos de Saúde Pública,36(2). https://doi.org/10.1590/0102$\underline{311 X 00037620}$

Carroll, J. B. (1997). Psychometrics, Intelligence, and Public Perception, 24(1), 25-52.

Caserotti, M., Girardi, P., Rubaltelli, E., Tasso, A., Lotto, L., \& Gavaruzzi, T. (2021). Associations of COVID-19 risk perception with vaccine hesitancy over time for Italian $\begin{array}{lllll}\text { residents. Social science } \quad \& \quad \text { medicine } & \text { (1982), 272, } 113688 .\end{array}$ https://doi.org/10.1016/j.socscimed.2021.113688

Cerda, A. A., \& García, L. Y. (2021). Hesitation and Refusal Factors in Individuals' Decision-Making Processes Regarding a Coronavirus Disease 2019 Vaccination. Frontiers in public health, 9, 626852. https://doi.org/10.3389/fpubh.2021.626852

Chapman, G.B., \& Coups, E.J. (2006). Emotions and preventive health behavior: worry, regret, and influenza vaccination. Health Psychol, 25, 82-90. https://doi.org/ 10.1037/0278-6133.25.1.82.

Consórcio Nacional de Veículos de Imprensa (2020a). [acesso em 28 de agosto de 2021]. Disponível em: https://g1.globo.com/bemestar/coronavirus/noticia/2020/07/31/casos-emortes-por-coronavirus-no-brasil-em-31-de-julho-segundo-consorcio-de-veiculos-deimprensa.ghtml

Consórcio Nacional de Veículos de Imprensa (2020b). [acesso em 28 de agosto de 2021]. Disponível em: https://g1.globo.com/bemestar/coronavirus/noticia/2020/10/19/casos-emortes-por-coronavirus-em-19-de-outubro-segundo-consorcio-de-veiculos-deimprensa.ghtml

Consórcio Nacional de Veículos de Imprensa (2021). [acesso em 28 de agosto de 2021]. Disponível em: https://g1.globo.com/bemestar/coronavirus/noticia/2021/02/01/brasiltem-295-mil-mortes-por-covid-19-em-janeiro-numero-e-o-terceiro-maior-desde-oinicio-da-pandemia.ghtml

Coronavirus, Kahn, B., Brown, L., Foege, W., \& Gayle, H. (Eds.). (2020). Framework for Equitable Allocation of COVID-19 Vaccine. National Academies Press (US). 
Cuan-Baltazar, J. Y., Muñoz-Perez, M. J., Robledo-Vega, C., Pérez-Zepeda, M. F., \& Soto-Vega, E. (2020). Misinformation of COVID-19 on the Internet: Infodemiology Study. JMIR public health and surveillance, 6(2), e18444. https://doi.org/10.2196/18444

Da Silva, J. A. (2003). Inteligência Humana: Abordagens Biológicas e Cognitivas. São Paulo: Lovise.

Datafolha. Pesquisa Nacional. [acesso em 20 de dezembro 2020b]. Disponível em: https://www1.folha.uol.com.br/equilibrioesaude/2020/11/adesao-a-vacinacao-contracovid-19-cai-mostra-datafolha.shtml

Datafolha. Pesquisa Nacional. [acesso em 20 de dezembro 2020a]. Disponível em: http://media.folha.uol.com.br/datafolha/2020/12/14/ad8a599a43kj9u94hu9hv9u94j99no 278vc.pdfDouglas, K. M., Sutton, R. M., \& Cichocka, A. (2017). The psychology of conspiracy theories. Current Directions in Psychological Science, 26, 538-542. doi:10.1177/0963721417718261

Douglas, K. M., Uscinski, j. E., Sutton, R. M., Cichocka, A., Nefes, T., Ang, C. S., \& Deravi, F. (2019). Understanding conspiracy theories. Political Psychology, 40, 3-35. doi:10.1111/pops.12568

Dubé, E., Vivion, M., \& MacDonald, N. E. (2015). Vaccine hesitancy, vaccine refusal and the anti-vaccine movement: influence, impact and implications. Expert review of vaccines, 14(1), 99-117. https://doi.org/10.1586/14760584.2015.964212

Duncan, L. A., Schaller, M., Park, J. H. (2009). Perceived vulnerability to disease: Development and validation of a 15-item self-report instrument. Personality and Individual Differences, 47, 541-546. https://doi.org/10.1016/j.paid.2009.05.001

Eysenbach, G., Powell, J., Kuss, O., \& Sa, E. R. (2002). Empirical studies assessing the quality of health information for consumers on the world wide web: a systematic review. JAMA, 287(20), 2691-2700. https://doi.org/10.1001/jama.287.20.2691

Feemster, K. A. (2018). Vaccines: what everyone needs to know. New York, NY: Oxford University Press. 
Fishbein, M., Cappella, J.N. (2006). The Role of Theory in Developing Effective Health Communications. Journal of Communication, $56(1), 1-$ 17, https://doi.org/10.1111/j.1460-2466.2006.00280.x

Fishbein, M., \& Ajzen, I. (2010). Belief, attitude, intention, and behavior: an introduction to theory and research. Reading, Mass: Addison-Wesley Pub. Co; 1975.

Galliford, N., \& Furnham, A (2017). Individual difference factors and beliefs in medical and political conspiracy theories. Scandinavian Journal ofPsychology, 58, 422-428. doi:10.1111/sjop.12382

Gramacho, W. G., \& Turgeon, M. (2021). When politics collides with public health: COVID-19 vaccine country of origin and vaccination acceptance in Brazil. Vaccine, 39(19), 2608-2612. https://doi.org/10.1016/j.vaccine.2021.03.080

Gunaratne, K., Coomes, E. A., \& Haghbayan, H. (2019). Temporal trends in anti-vaccine discourse on $\quad$ Twitter. Vaccine, 37(35), 4867-4871. https://doi.org/10.1016/j.vaccine.2019.06.086

Habib, S., Saleem, S., Mahmood, Z. (2013) Development and validation of social intelligence scale for university students. Pakistan J Psy-chol Res, 28(1):65-83.

Hotez P. J. (2020). COVID19 meets the antivaccine movement. Microbes and infection, 22(4-5), 162-164. https://doi.org/10.1016/j.micinf.2020.05.010

Hunt, E. (2010). Human Intelligence. Cambridge: Cambridge University Press. doi:10.1017/CBO9780511781308

Ibuka, Y., Chapman, G.B., Meyers, L.A., Li, M., Galvani, A.P. (2010). The dynamics of risk perceptions and precautionary behavior in response to 2009 (H1N1) pandemic influenza. BMC Infect. Dis. 10 https://doi.org/10.1186/1471-2334-10-296.

Jetten, J., Reicher, S.D., Cruwys, T. (2020). Together Apart: The Psychology of COVID19. Ed. SAGE Publications, 1.

Karlsson, L. C., Soveri, A., Lewandowsky, S., Karlsson, L., Karlsson, H., Nolvi, S., Karukivi, M., Lindfelt, M., \& Antfolk, J. (2021). Fearing the disease or the vaccine: The case of COVID-19. Personality and individual differences, 172, 110590. https://doi.org/10.1016/j.paid.2020.110590 
Kosmitzki, C., \& John, O. P. (1993). The implicit use of explicit conceptions of social intelligence. Personality and Individual Differences, 15(1), 1123. https://doi.org/10.1016/0191-8869(93)90037-4

Lantian, A, Muller, D., Nurra, c., \& Douglas, K M. (2017). "I know things they don't know!": The role of need for uniqueness in belief in conspiracy theories. Social Psychology, 48, 160-173. doi:10.1027/1864-9335/a000306

Larson, H. J., Clarke, R. M., Jarrett, C., Eckersberger, E., Levine, Z., Schulz, W. S., \& Paterson, P. (2018). Measuring trust in vaccination: A systematic review. Human vaccines \& immunotherapeutics, 14(7), 1599-1609. https://doi.org/10.1080/21645515.2018.1459252

Larson, H. J., Jarrett, C., Eckersberger, E., Smith, D. M., \& Paterson, P. (2014). Understanding vaccine hesitancy around vaccines and vaccination from a global perspective: a systematic review of published literature, 2007-2012. Vaccine, 32(19), 2150-2159. https://doi.org/10.1016/j.vaccine.2014.01.081

MacDonald, N. E., \& SAGE Working Group on Vaccine Hesitancy (2015). Vaccine hesitancy: Definition, scope and determinants. Vaccine, 33(34), 4161-4164. https://doi.org/10.1016/j.vaccine.2015.04.036

Malik, A. A., McFadden, S. M., Elharake, J., \& Omer, S. B. (2020). Determinants of COVID-19 vaccine acceptance in the US. EClinicalMedicine, 26, 100495. https://doi.org/10.1016/j.eclinm.2020.100495

Martin, L. R., \& Petrie, K. J. (2017). Understanding the Dimensions of Anti-Vaccination Attitudes: the Vaccination Attitudes Examination (VAX) Scale. Annals of behavioral medicine : a publication of the Society of Behavioral Medicine, 51(5), 652-660. https://doi.org/10.1007/s12160-017-9888-y

Muller, A., Sirianni, L.A., Addante, R.J. (2021). Neural correlates of the Dunning-Kruger effect. The European Journal of Neuroscience, 53(2), 460-484. https://doi.org/10.1111/ejn.14935

Murphy, J., Vallières, F., Bentall, R.P. et al. (2021). Psychological characteristics associated with COVID-19 vaccine hesitancy and resistance in Ireland and the United Kingdom. Nat Commun., 12, 29. https://doi.org/10.1038/s41467-020-20226-9 
Nassaralla, A.P.A., Doumit, A.M., Melo, F.C., Léon, L.C., Vidal, R.A.R., Moura, L.R. (2019). Dimensões e consequências do movimento antivacina na realidade brasileira. Rev. Educação em Saúde, 7(1), 120-125.

National Academies of Sciences, Engineering, and Medicine; Health and Medicine Division; Board on Population Health and Public Health Practice; Board on Health Sciences Policy; Committee on Equitable Allocation of Vaccine for the Novel

National Institute of Health - National Institute of Allergy and Infectious Disease. (2020). Safety and immunogenicity study of 2019-nCoV vaccine (mRNA- 1273) for prophylaxis of SARS-CoV-2 infection (COVID-19). https:// clinicaltrials.gov/ct2/show/NCT04283461.

Oliveira, M. R. A, \& Da Silva, J. A. (2021). Reações Físicas, Cognitivas, Psicológicas e Comportamentais como indicadores de Saúde à Pandemia COVID-19 - Um Retrato Luso-Brasileiro. In L. A. M. Campos, S. F. Paiva, F. A. Cardoso \& J. A. Da Silva (Orgs.), Fatores Cognitivos-Comportamentais e o Movimento Antivacina: efeitos no controle da pandemia da COVID-19 (pp. 185-200). Editora CRV.

Ortiz-Sánchez, E., Velando-Soriano, A., Pradas-Hernández, L., Vargas-Román, K., Gómez-Urquiza, J. L., Cañadas-De la Fuente, G. A., \& Albendín-García, L. (2020). Analysis of the Anti-Vaccine Movement in Social Networks: A Systematic Review. International journal of environmental research and public health, 17(15), 5394. https://doi.org/10.3390/ijerph17155394

Park, T., Ju, I., Ohs, J.E., \& H., A. (2020). Optimistic bias and preventive behavioral engagement in the context of COVID-19. Research in Social and Administrative Pharmacy, 17(1), 1859-1866. https://doi.org/10.1016/j.sapharm.2020.06.004

Passos, L., Prazeres, F., Teixeira, A., \& Martins, C. (2020). Impact on Mental Health Due to COVID-19 Pandemic: Cross-Sectional Study in Portugal and Brazil. International journal of environmental research and public health,17(18), 6794. https://doi.org/10.3390/ijerph17186794

Petousis-Harris, H., \& Alley, L. (2020). Impact of antivaccination campaigns on health worldwide: lessons for Australia and the global community. The Medical journal of Australia, 213(7), 300-301.e1. https://doi.org/10.5694/mja2.50779 
Pinsker, D. M., McFarland, K., \& Stone, V. E. (2011). The Social Vulnerability Scale for Older Adults: An Exploratory and Confirmatory Factor Analytic Study. Journal of elder abuse \& neglect, 23(3), 246-272. https://doi.org/10.1080/08946566.2011.584049

Pummerer, L., Böhm, R., Lilleholt, L., Winter, K., Zettler, I., \& Sassenberg, K. (2021). Conspiracy Theories and Their Societal Effects During the COVID-19 Pandemic. Social Psychological and Personality Science. https://doi.org/10.1177/19485506211000217

Ritchie, H., Mathieu, E., Rodés-Guirao, L., Appel, C., Giattino, C., Ortiz-Ospina, E., Hasell, J., Macdonald, B., Beltekian, D., \& Roser, M. (2021) - "Coronavirus Pandemic (COVID-19)". [acesso em 15 de julho de 2021] Disponível em: https://ourworldindata.org/coronavirus

Reuters. Secom faz propaganda com frase de Bolsonaro contra obrigatoriedade da vacina. UOL. (2020) [acesso em 01 de setembro de 2020]. Disponível em: https://noticias.uol.com.br/ultimas-noticias/reuters/2020/09/01/secom-faz-propagandacom-frase-de-bolsonaro-contra-obrigatoriedade-da-vacina.htm

Salmon, D. A., Dudley, M. Z., Glanz, J. M., \& Omer, S. B. (2015). Vaccine Hesitancy: Causes, Consequences, and a Call to Action. American journal of preventive medicine, 49(6 Suppl 4), S391-S398. https://doi.org/10.1016/j.amepre.2015.06.009

Skjefte, M., Ngirbabul, M., Akeju, O., Escudero, D., Hernandez-Diaz, S., Wyszynski, D. F., \& Wu, J. W. (2021). COVID-19 vaccine acceptance among pregnant women and mothers of young children: results of a survey in 16 countries. European journal of epidemiology, 36(2), 197-211. https://doi.org/10.1007/s10654-021-00728-6

Shapiro, G. K., Tatar, O., Dube, E., Amsel, R., Knauper, B., Naz, A., Perez, S., \& Rosberger, Z. (2018). The vaccine hesitancy scale: Psychometric properties and validation. Vaccine, 36(5), 660-667. https://doi.org/10.1016/j.vaccine.2017.12.043

Shapiro, G. K., Holding, A., Perez, S., Amsel, R., \& Rosberger, Z. (2016). Validation of the vaccine conspiracy beliefs scale. Papillomavirus research (Amsterdam, Netherlands), 2, 167-172. https://doi.org/10.1016/j.pvr.2016.09.001

Silvera, D. H., Martinussen, M., \& Dahl, T. I. (2001). The Troms $\varnothing$ Social Intelligence Scale, a self-report measure of social intelligence. Scandinavian journal of psychology, 42(4), 313-319. https://doi.org/10.1111/1467-9450.00242 
Slovic, P., Finucane, M.L., Peters, E., MacGregor, D.G. (2004). Risk as analysis and risk as feelings: some thoughts about affect, reason, risk, and rationality. Risk Anal.: Int. J. 24, 311-322. https://doi.org/10.1111/j.0272-4332.2004.00433.x.

Sternberg, R. J. (2000). Inteligência para o sucesso pessoal: como a inteligência prática e criativa determina o sucesso. Rio de Janeiro: Campus.

Succi, R. (2018). Vaccine refusal - what we need to know. Jornal de pediatria, 94(6), 574581. https://doi.org/10.1016/j.jped.2018.01.008

Taylor S. (2019). The Psychology of Pandemics: Preparing for the Next Global Outbreak of Infectious Disease. Cambridge Scholars Publishing.

Teunisse, A. K., Case, T. I., Fitness, J., \& Sweller, N. (2020). I should have known better: Development of a self-report measure of gullibility. Personality and Social Psychology Bulletin, 46(3), 408-423. https://doi.org/10.1177/0146167219858641.

Urrunaga-Pastor, D., Bendezu-Quispe, G., Herrera-Añazco, P., Uyen-Cateriano, A., ToroHuamanchumo, C. J., Rodriguez-Morales, A. J., Hernandez, A. V., \& Benites-Zapata, V. A. (2021). Cross-sectional analysis of COVID-19 vaccine intention, perceptions and hesitancy across Latin America and the Caribbean. Travel medicine and infectious disease, 41, 102059. https://doi.org/10.1016/j.tmaid.2021.102059

Vasconcellos-Silva, P.R., Castiel, L.D. (2020). COVID-19, as fakes news e o sono da razão comunicativa gerando monstros: a narrativa dos riscos e os riscos das narrativas. Cadernos de Saúde Pública, 36(7), e00101920. https://doi.org/10.1590/0102-311X00101920

Vasconcellos-Silva, P.R., Castiel, L.D., Griep, R.H. (2015). A sociedade de risco midiatizada, o movimento antivacinação e o risco do autismo. Ciência \& Saúde Coletiva, 20(2), 607-616. https://doi.org/10.1590/1413-81232015202.10172014

Wakefield AJ, Murch SH, Anthony A, Linnell J, Casson DM, Malik M, et al. Ileallymphoid- nodular hyperplasia, non-specific colitis, and pervasive developmental disorder in children. Lancet. 1998; 351:637-41.

Ward J. K. (2016). Rethinking the antivaccine movement concept: A case study of public criticism of the swine flu vaccine's safety in France. Social science \& medicine (1982), 159, 48-57. https://doi.org/10.1016/j.socscimed.2016.05.003 
Weitz, L., Bellach, L., Faltum, A., Berger, A., \& Maurer, W. (2020). Vaccine hesitancy : Report of a student study group. Wiener klinische Wochenschrift, 132(9-10), 243-252. https://doi.org/10.1007/s00508-020-01655-4

WHO, World Health Organization. (2020a). Coronavirus disease (COVID-19): situation report 106. World Health Organization; [acesso em 12 dez 2020]. Disponível em: https://www.who.int/emergencies/diseases/novel-coronavirus-2019/situation-reports.

WHO, World Health Organization. (2020b). DRAFT landscape of COVID-19 candidate vaccines - 20 April 2020. https://www.who.int/blueprint/priority-diseases/keyaction/novel-coronavirus-landscape-ncov.pdf.

WHO, World Health Organization. (2020c). Coronavirus disease (COVID-19) outbreak situation. Available at: https://www.who.int/emergencies/diseases/novel-coronavirus2019. Accessed June 2, 2020.

WHO, World Health Organization. (2019). Ten threats to global health in 2019 [acesso em 20 nov 2020]. Disponível em: https://www.who.int/ emergencies/ten-threats-to-globalhealth- in-2019

WHO, World Health Organization. (2014). Report of the SAGE Working Group on Vaccine Hesitancy. [acesso em 10 de novembro de 2020]. Disponível em: https://www.who.int/immunization/sage/meetings/2014/october/1_Report_WORKING_ GROUP_vaccine_hesitancy_final.pdf

WHO, World Health Organization. (2013). Global Vaccine Action Plan 2011-2020. Geneva: WHO. [acesso em 10 nov 2020]. Disponível em: http://www.who.int/immunization/global_vaccine_action_ plan/GVAP_doc_2011_2020/en/

Xiao, X., \& Wong, R. M. (2020). Vaccine hesitancy and perceived behavioral control: A meta-analysis. Vaccine, 38(33), $5131-5138$. https://doi.org/10.1016/j.vaccine.2020.04.076

Zajenkowski, M., \& Czarna, A. (2015). What makes narcissists unhappy? Subjectively assessed intelligence moderates the relationship between narcissism and psychological 
well-being. Personality and Individual Differences, 77, 50-54. https://doi.org/10.1016/j.paid.2014.12.045

Anexo A

INVENTÁRIO DE PERSONALIDADE NARCISISTA - (IPN)-16

INSTRUÇÕES: Este é um Teste de Personalidade para ajudar você a conhecer mais sobre si próprio. Há $\mathbf{1 6}$ afirmações pareadas, isto é, uma na frente da outra. Leia atentamente todas elas, duas a duas, e escolha uma afirmativa de cada par, a qual espelhe melhor seu sentimento.

\begin{tabular}{|c|c|}
\hline ( ) Eu sei que sou bom, pois é o que todos dizem. & $\begin{array}{l}\text { ( ) Quando outras pessoas me elogiam eu me sinto } \\
\text { envergonhado }\end{array}$ \\
\hline ( ) Eu gosto de ser o centro das atenções. & ( ) Eu prefiro me misturar no meio da multidão \\
\hline ( ) Eu acho que sou uma pessoa especial. & ( ) Eu não sou melhor ou pior do que os demais \\
\hline ( ) Eu gosto de ter autoridade sobre outros. & ( ) Eu não me importo de seguir ordens \\
\hline ( ) Eu acho fácil manipular outras pessoas. & ( ) Eu não gosto de manipular outras pessoas \\
\hline ( ) Eu insisto em receber o respeito que mereço. & ( ) Eu usualmente recebo o respeito que eu mereço \\
\hline ( ) Eu me exibo se tenho a oportunidade. & ( ) Eu tento não me mostrar \\
\hline ( ) Eu sempre sei o que estou fazendo. & $\begin{array}{l}\text { ( ) Às vezes eu não tenho certeza do que eu estou } \\
\text { fazendo }\end{array}$ \\
\hline ( ) Todos gostam de ouvir as minhas histórias. & ( ) Às vezes eu conto histórias boas \\
\hline ( ) Eu espero bastante dos demais. & ( ) Eu gosto de fazer coisas para os demais \\
\hline ( ) Eu realmente gosto de ser o centro das atenções. & ( ) Ser o centro das atenções me deixa desconcertado \\
\hline $\begin{array}{l}\text { ( ) Os demais sempre reconhecem a minha } \\
\text { autoridade. }\end{array}$ & ( ) Ser uma autoridade não significa tanto para mim \\
\hline ( ) Eu serei uma grande pessoa. & ( ) Eu espero ser bem sucedido \\
\hline $\begin{array}{l}\text { ( ) Eu posso fazer com que qualquer um faça o que eu } \\
\text { quero. }\end{array}$ & $\begin{array}{l}\text { ( ) As pessoas ocasionalmente acreditam no que eu } \\
\text { falo }\end{array}$ \\
\hline ( ) Eu sou mais capaz do que os demais. & $\begin{array}{l}\text { ( ) Tem muitas coisas que posso aprender com os } \\
\text { demais }\end{array}$ \\
\hline ( ) Eu sou extraordinário. & ( ) Eu sou bem parecido com os demais \\
\hline
\end{tabular}




\section{Anexo B}

\section{ESCALA DE AUTO-RELATO CREDULIDADE}

INSTRUÇÕES: Abaixo segue uma série de afirmações sobre crenças e

comportamentos. Leia atentamente cada uma delas e indique, de 1 a 7, o quão

verdadeiro estas afirmações referem-se particularmente a você. Para sua escolha, 1

significa que você discorda totalmente e 7 você concorda totalmente com a afirmação escolhida.

\begin{tabular}{|c|}
\hline AFIRMAÇÕES \\
\hline $\begin{array}{l}\text { 1. Eu sou muito experto quando alguém está tentando me enganar } \\
\text { Discorda fortemente } 1234567 \text { concorda fortemente }\end{array}$ \\
\hline $\begin{array}{l}\text { 2. Geralmente sou rápido em perceber quando alguém está tentando me trapacear } \\
\text { Discorda fortemente } 1234567 \text { concorda fortemente }\end{array}$ \\
\hline $\begin{array}{l}\text { 3. Sou muito lento em perceber se alguém está me enganando. } \\
\text { Discorda fortemente } 12334567 \text { concorda fortemente }\end{array}$ \\
\hline $\begin{array}{l}\text { 4. Percebo rapidamente quando alguém está me passando a perna. } \\
\text { Discorda fortemente } 1234567 \text { concorda fortemente }\end{array}$ \\
\hline $\begin{array}{l}\text { 5. Geralmente, eu levo um tempo para "cair a ficha" (detectar) quando alguém está me } \\
\text { enganando. } \\
\quad \text { Discorda fortemente } 12334567 \text { concorda fortemente }\end{array}$ \\
\hline $\begin{array}{l}\text { 6. Não sou tão bom em ler os sinais de que alguém está tentando me manipular. } \\
\text { Discorda fortemente } 1234567 \text { concorda fortemente }\end{array}$ \\
\hline $\begin{array}{l}\text { 7. Minha família acha que sou um alvo fácil para os golpistas. } \\
\text { Discorda fortemente } 12345567 \text { concorda fortemente }\end{array}$ \\
\hline $\begin{array}{l}\text { 8. Se é provável que alguém caia num golpe, ou farsa, esse alguém sou eu. } \\
\text { Discorda fortemente } 1234567 \text { concorda fortemente }\end{array}$ \\
\hline
\end{tabular}




\begin{tabular}{|c|}
\hline $\begin{array}{l}\text { 9. Meus amigos acham que eu sou facilmente enganado } \\
\text { Discorda fortemente } 1234567 \text { concorda fortemente }\end{array}$ \\
\hline $\begin{array}{l}\text { 10. No geral, sou facilmente manipulado. } \\
\text { Discorda fortemente } 1234567 \text { concorda fortemente }\end{array}$ \\
\hline $\begin{array}{l}\text { 11. As pessoas pensam que sou uma pessoa pouco ingênua. } \\
\text { Discorda fortemente } 1234567 \text { concorda fortemente }\end{array}$ \\
\hline $\begin{array}{l}\text { 12. Eu acho que sou mais crédulo que a pessoa média. } \\
\text { Discorda fortemente } 1234567 \text { concorda fortemente }\end{array}$ \\
\hline
\end{tabular}

\section{Anexo C \\ ESCALA DE PERCEPÇÃO DA VULNERABILIDADE À DOENÇA INFECCIOSA}

Abaixo são descritas diferentes afirmações sobre a transmissão de doenças infecciosas. Por favor, indique o quanto você concorda (ou discorda) de cada afirmação considerando à sua própria susceptibilidade às doenças infecciosas.

\begin{tabular}{|c|c|c|c|c|c|c|c|}
\hline Afirmações & $\begin{array}{l}\text { Discordo } \\
\text { fortemen } \\
\text { te }\end{array}$ & Discordo & $\begin{array}{c}\text { Discordo } \\
\text { mais ou } \\
\text { menos }\end{array}$ & $\begin{array}{c}\text { Nem } \\
\text { concordo e } \\
\text { nem } \\
\text { discordo } \\
\text { (neutro) }\end{array}$ & $\begin{array}{l}\text { Concordo } \\
\text { mais ou } \\
\text { menos }\end{array}$ & $\begin{array}{l}\text { Concor } \\
\text { do }\end{array}$ & $\begin{array}{l}\text { Concor } \\
\text { do } \\
\text { forteme } \\
\text { nte }\end{array}$ \\
\hline $\begin{array}{c}\text { 1.Realmente me incomoda } \\
\text { quando as pessoas espirram sem } \\
\text { cobrir a boca }\end{array}$ & 1 & 2 & 3 & 4 & 5 & 6 & 7 \\
\hline $\begin{array}{l}\text { 2.Se uma doença está circulando, } \\
\text { eu vou pegá-la. }\end{array}$ & 1 & 2 & 3 & 4 & 5 & 6 & 7 \\
\hline $\begin{array}{l}\text { 3.Não me importo em } \\
\text { compartilhar uma garrafa de água } \\
\text { com um amigo. }\end{array}$ & 1 & 2 & 3 & 4 & 5 & 6 & 7 \\
\hline $\begin{array}{l}\text { 4.Não gosto de escrever com um } \\
\text { lápis que alguém obviamente } \\
\text { tenha mastigado }\end{array}$ & 1 & 2 & 3 & 4 & 5 & 6 & 7 \\
\hline $\begin{array}{l}\text { 5.Minhas experiências passadas } \\
\text { me fazem acreditar que não tenho } \\
\text { probabilidade de ficar doente, } \\
\text { mesmo quando meus amigos } \\
\text { estão doentes. }\end{array}$ & 1 & 2 & 3 & 4 & 5 & 6 & 7 \\
\hline $\begin{array}{l}\text { 6.Eu tenho um histórico de } \\
\text { suscetibilidade a doenças } \\
\text { infecciosas }\end{array}$ & 1 & 2 & 3 & 4 & 5 & 6 & 7 \\
\hline $\begin{array}{l}\text { 7.Prefiro lavar as mãos logo após } \\
\text { apertar a mão de alguém }\end{array}$ & 1 & 2 & 3 & 4 & 5 & 6 & 7 \\
\hline $\begin{array}{l}\text { 8.Em geral, sou muito suscetível } \\
\text { a resfriados, gripes e outras } \\
\text { doenças infecciosas }\end{array}$ & 1 & 2 & 3 & 4 & 5 & 6 & 7 \\
\hline $\begin{array}{l}\text { 9.Não gosto de usar roupas } \\
\text { usadas porque não sei como era a } \\
\text { pessoa que as vestiu no passado. }\end{array}$ & 1 & 2 & 3 & 4 & 5 & 6 & 7 \\
\hline $\begin{array}{l}\text { 10.Eu sou mais propenso do que } \\
\text { as pessoas ao meu redor a pegar } \\
\text { uma doença infecciosa }\end{array}$ & 1 & 2 & 3 & 4 & 5 & 6 & 7 \\
\hline
\end{tabular}




\begin{tabular}{|c|c|c|c|c|c|c|}
\hline $\begin{array}{c}\text { 11.Minhas mãos não ficam sujas } \\
\text { depois de tocar em dinheiro }\end{array}$ & 1 & 2 & 3 & 4 & 5 & 7 \\
\hline $\begin{array}{c}\text { 12.É improvável que eu pegue } \\
\text { um resfriado, gripe ou outra } \\
\text { doença, mesmo que ela esteja } \\
\text { ocorrendo }\end{array}$ & 1 & 2 & 3 & 4 & 5 & 6 \\
\hline $\begin{array}{c}\text { 13.Não fico ansioso por estar } \\
\text { perto de pessoas doentes }\end{array}$ & 1 & 2 & 3 & 4 & 5 & 7 \\
\hline $\begin{array}{c}\text { 14, Meu sistema imunológico me } \\
\text { protege da maioria das doenças } \\
\text { que outras pessoas sofrem }\end{array}$ & 1 & 2 & 3 & 4 & 5 & 7 \\
\hline $\begin{array}{c}\text { 15.Evito usar telefones públicos, } \\
\text { celulares de outras pessoas, } \\
\text { devido ao risco de pegar algo do } \\
\text { usuário anterior }\end{array}$ & 1 & 2 & 3 & 4 & 5 & 6 \\
\hline
\end{tabular}

\section{Anexo D}

\section{Escala de aderência às teorias conspiratórias antivacina}

Instruções: Abaixo estão listadas oito afirmações acerca das concepções das pessoas acerca de vacinas. Leia cada afirmação e, dependendo de quanto você concorda com cada uma delas, circule um número de 1 a 7 . Um valor igual a 1 significa que você discorda totalmente da afirmação. Um valor igual a 7 significa que você concorda plenamente com a mesma. Suas respostas devem levar em consideração como você as concebe no contexto da pandemia pela COVID-19, que está assolando o Brasil há 5 meses.

\begin{tabular}{|c|c|c|c|c|c|c|c|}
\hline Afirmações & $\begin{array}{l}1 \text { Discordo } \\
\text { Totalmente }\end{array}$ & 2 & 3 & 4 & 5 & 6 & $\begin{array}{l}7 \text { Concordo } \\
\text { Totalmente }\end{array}$ \\
\hline \multicolumn{8}{|l|}{$\begin{array}{l}\text { 1.Imunizações permitem ao governo rastrear e } \\
\text { controlar pessoas. }\end{array}$} \\
\hline \multicolumn{8}{|l|}{$\begin{array}{l}\text { 2. Vacinas são prejudiciais, e esse fato é ocultado } \\
\text { do público. }\end{array}$} \\
\hline \multicolumn{8}{|l|}{$\begin{array}{l}\text { 3.Pequenos dispositivos são colocados em } \\
\text { vacinas a fim de rastrear indivíduos. }\end{array}$} \\
\hline \multicolumn{8}{|l|}{$\begin{array}{l}\text { 4.Companhias farmacêuticas, cientistas e } \\
\text { acadêmicos trabalham em conjunto para ocultar } \\
\text { os perigos associados às vacinas. }\end{array}$} \\
\hline \multicolumn{8}{|l|}{ 5.Vacinas não sofrem adulterações. } \\
\hline \multicolumn{8}{|l|}{$\begin{array}{l}6 . O \text { governo está tentando ocultar o vínculo } \\
\text { entre vacinas e autismo. }\end{array}$} \\
\hline \multicolumn{8}{|l|}{$\begin{array}{l}\text { 7.Pequenos dispositivos são implantados em } \\
\text { vacinas para a realização de experimentos de } \\
\text { controle da mente. }\end{array}$} \\
\hline $\begin{array}{l}\text { 8. A vacina da gripe permite ao governo } \\
\text { monitorar os idosos por meio da implantação de } \\
\text { pequenos dispositivos de rastreamento. }\end{array}$ & & & & & & & \\
\hline
\end{tabular}




\section{Anexo E \\ ESCALA DE ATITUDES ANTIVACINAÇÃO}

INSTRUÇÕES: Abaixo estão listadas 12 afirmações sobre as atitudes que as pessoas têm em relação à vacinação. Leia cada afirmação e, dependendo do quanto você concorda com cada uma delas, circule um número, de 1 a 6 , que represente sua atitude revelada em cada uma delas. Um valor igual 1 significa que você concorda totalmente com a afirmação. Um valor igual a 6 significa que você discorda totalmente da mesma. Suas respostas devem levar em consideração suas atitudes em relação à vacinação dentro do contexto da pandemia da Covid-19 que estamos vivenciando ao longo dos últimos 5 meses.

\begin{tabular}{|c|}
\hline $\begin{array}{l}\text { 1. Sinto-me seguro depois de ser vacinado. } \\
\text { Concordo totalmente } 123456 \text { Discordo totalmente }\end{array}$ \\
\hline $\begin{array}{l}\text { 2. Posso confiar em vacinas para parar doenças infecciosas graves. } \\
\text { Concordo totalmente } 123456 \text { Discordo totalmente }\end{array}$ \\
\hline $\begin{array}{l}\text { 3. Sinto-me protegido depois de ser vacinado. } \\
\text { Concordo totalmente } 123456 \text { Discordo totalmente }\end{array}$ \\
\hline $\begin{array}{l}\text { 4. Embora a maioria das vacinas pareça ser segura, pode haver problemas que ainda não descobrimos. } \\
\qquad \text { Concordo totalmente } \begin{array}{l}1 \\
2\end{array} 456 \text { Discordo totalmente }\end{array}$ \\
\hline $\begin{array}{l}\text { 5. As vacinas podem causar problemas imprevistos em crianças. } \\
\text { Concordo totalmente } 123456 \text { Discordo totalmente }\end{array}$ \\
\hline $\begin{array}{l}\text { 6. Preocupo-me com os efeitos desconhecidos das vacinas no futuro. } \\
\text { Concordo totalmente } 123456 \text { Discordo totalmente }\end{array}$ \\
\hline 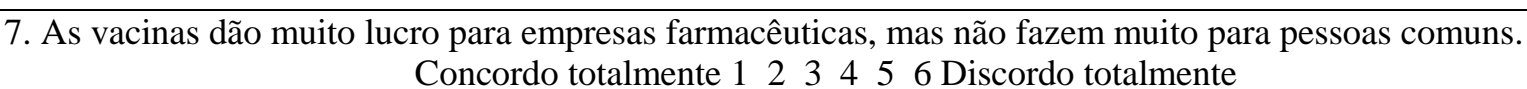 \\
\hline $\begin{array}{l}\text { 8. As autoridades promovem a vacinação para ganho financeiro, não para a saúde das pessoas. } \\
\text { Concordo totalmente } \begin{array}{l}123456 \text { Discordo totalmente }\end{array}\end{array}$ \\
\hline
\end{tabular}




\begin{tabular}{|c|}
\hline $\begin{array}{l}\text { 9. Os programas de vacinação são um grande golpe. } \\
\text { Concordo totalmente } \begin{array}{lllll}2 & 3 & 456 \text { Discordo totalmente }\end{array}\end{array}$ \\
\hline $\begin{array}{l}\text { 10. A imunidade natural dura mais que uma vacinação. } \\
\text { Concordo totalmente } 123456 \text { Discordo totalmente }\end{array}$ \\
\hline $\begin{array}{l}\text { 11. A exposição natural a vírus e germes oferece a proteção mais segura. } \\
\text { Concordo totalmente } 123456 \text { Discordo totalmente }\end{array}$ \\
\hline 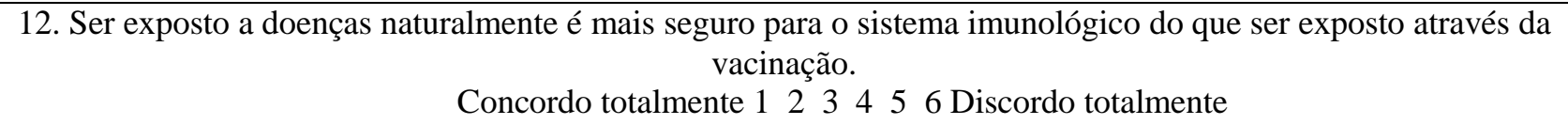 \\
\hline
\end{tabular}

\section{Anexo F \\ ESCALA DE HESITAÇÃO À VACINA}

Abaixo encontra-se um questionário de crenças e comportamentos. Leia cada afirmação com atenção e, usando as categorias numéricas que variam de 1 (um) a 5 (cinco), indique o quanto você concorda ou discorda das mesmas. Observe que, algumas vezes, as categorias numéricas começam da maior (5) para a menor (1).

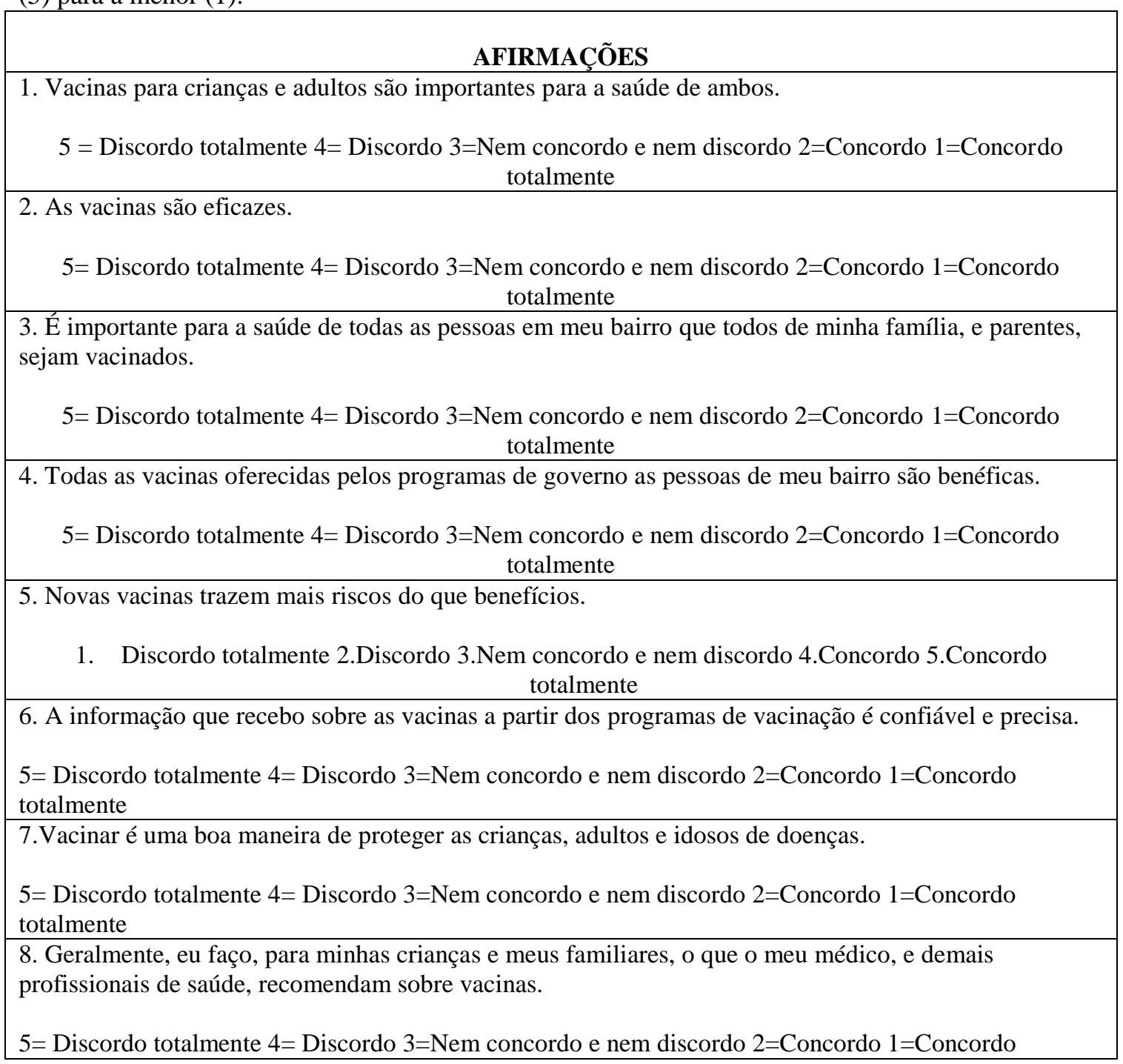


totalmente

9. Eu me preocupo com as reações, ou efeitos, adversos que as vacinas provocam.

1=Discordo totalmente $2=$ Discordo $3=$ Nem concordo e nem discordo $4=$ Concordo $5=$ Concordo totalmente

10. Minhas crianças e/ou meus familiares necessitam ou não necessitam de vacinas para as doenças que não são mais comuns.

1=Discordo totalmente $2=$ Discordo $3=$ Nem concordo e nem discordo $4=$ Concordo $5=$ Concordo totalmente

\section{Anexo G}

\section{Escala de Inteligência Social Auto Avaliada}

As pessoas diferem em relação à inteligência geral, podendo ter um nível baixo, médio ou alto da mesma. Usando a escala abaixo, verifique em qual opção você se situa ao comparar sua inteligência geral com a de outras pessoas. Marque o nível que entende ser correspondente a sua opinião.

1 a 2 - Muito baixa

3 a 4 - Baixa

5 a 6 - Média

7 a 8 - Alta

9 a 10 - Muito alta

\section{Como você considera sua inteligência com base nas informações acima?}

$\begin{array}{llllllllll}\text { Muito baixa } 1 & 2 & 3 & 4 & 5 & 6 & 7 & 8 & 9 & 10 \text { Muito Alta }\end{array}$




\section{Escala de Inteligência Social}

\section{Anexo H}

Por favor, preencha o seguinte questionário. Não pense muito nas suas respostas. Leia cada pergunta com atenção e indique o quanto essas afirmações são verdadeiras em uma escala de 1 (Descreve-me mal) a 7 (Descreve-me bem).

\section{Descreve-me mal 1234567 Descreve-me bem}

1. Eu posso prever o comportamento de outras pessoas

2. Muitas vezes sinto que é difícil entender as escolhas dos outros

3. Eu sei como minhas ações farão os outros se sentirem

4. Costumo me sentir inseguro em relação a novas pessoas que não conheço

5. As pessoas geralmente me surpreendem com o que fazem

6. Eu entendo os sentimentos de outras pessoas

7. Eu me encaixo facilmente em situações sociais

8. Outras pessoas ficam com raiva de mim sem que eu seja capaz de explicar por que

9. Entendo os desejos dos outros

10. Sou bom em entrar em novas situações e conhecer pessoas pela primeira vez

11. Parece que as pessoas ficam com raiva ou irritadas comigo quando digo o que penso

12. Eu tenho dificuldade em me dar bem com outras pessoas

13. Acho as pessoas imprevisíveis

14. Muitas vezes consigo entender o que os outros estão tentando realizar sem que eles necessitem me dizer qualquer coisa 
15. Levo muito tempo para conhecer bem os outros

16. Costumo magoar outras pessoas sem perceber

17. Posso prever como os outros reagirão ao meu comportamento

18. Sou bom em me relacionar bem com novas pessoas

19. Muitas vezes consigo entender o que os outros realmente querem dizer através de suas expressões faciais, linguagem corporal, etc.

20. Freqüentemente, tenho problemas para encontrar bons tópicos de conversa

21. Muitas vezes me surpreendo com a reação dos outros ao que faço

\section{Anexo I \\ ESCALA DE VULNERABILIDADE SOCIAL}

INSTRUÇÕES: Abaixo encontra-se um questionário sobre crenças e comportamentos. Leia cada pergunta com atenção e indique o quanto essas afirmações são verdadeiras em uma escala de 0 (Nunca) a 4 (Sempre).

\begin{tabular}{|c|c|c|c|c|}
\hline \multicolumn{5}{|c|}{ 1. Fui convencido a comprar itens desnecessários. } \\
\hline $\begin{array}{r}\text { Nunca } \\
0\end{array}$ & $\begin{array}{c}\text { Raramente } \\
1\end{array}$ & $\begin{array}{c}\text { Às vezes } \\
2\end{array}$ & $\begin{array}{l}\text { Frequentemente } \\
\quad 3\end{array}$ & $\begin{array}{l}\text { Sempre } \\
4\end{array}$ \\
\hline \multicolumn{5}{|c|}{ 2. Paguei por itens que nunca chegaram. } \\
\hline Nunca & Raramente & Às vezes & Frequentemente & Sempre \\
\hline 0 & 1 & 2 & 3 & 4 \\
\hline \multicolumn{5}{|c|}{ 3. Eu apliquei em investimentos duvidosos. } \\
\hline Nunca & Raramente & Às vezes & Frequentemente & Sempre \\
\hline 0 & 1 & 2 & 3 & 4 \\
\hline \multicolumn{5}{|c|}{ 4. Fui persuadido a fazer grandes doações. } \\
\hline Nunca & Raramente & Às vezes & Frequentemente & Sempre \\
\hline 0 & 1 & 2 & 3 & 4 \\
\hline \multicolumn{5}{|c|}{ 5. Fui enganado por golpes postais. } \\
\hline Nunca & Raramente & Às vezes & Frequentemente & Sempre \\
\hline 0 & 1 & 2 & 3 & 4 \\
\hline \multicolumn{5}{|c|}{ 6. Forneci os detalhes da minha conta bancária a um estranho. } \\
\hline Nunca & Raramente & Às vezes & Frequentemente & Sempre \\
\hline 0 & 1 & 2 & 3 & 4 \\
\hline \multicolumn{5}{|c|}{ 7. Fui enganado a pagar as contas de outras pessoas. } \\
\hline Nunca & Raramente & Ăs vezes & Frequentemente & Sempre \\
\hline 0 & 1 & 2 & 3 & 4 \\
\hline \multicolumn{5}{|c|}{ 8. Fui convencido a assinar livros, revistas e outras obras indesejadas } \\
\hline Nunca & Raramente & Às vezes & Frequentemente & Sempre \\
\hline 0 & 1 & 2 & 3 & 4 \\
\hline \multicolumn{5}{|c|}{ 9. Inquestionavelmente, acredito no que me dizem. } \\
\hline Nunca & Raramente & Às vezes & Frequentemente & Sempre \\
\hline 0 & 1 & 2 & 3 & 4 \\
\hline \multicolumn{5}{|c|}{ 10. Eu acredito em coisas que são claramente falsas. } \\
\hline Nunca & Raramente & Às vezes & Frequentemente & Sempre \\
\hline 0 & 1 & 2 & 3 & 4 \\
\hline
\end{tabular}




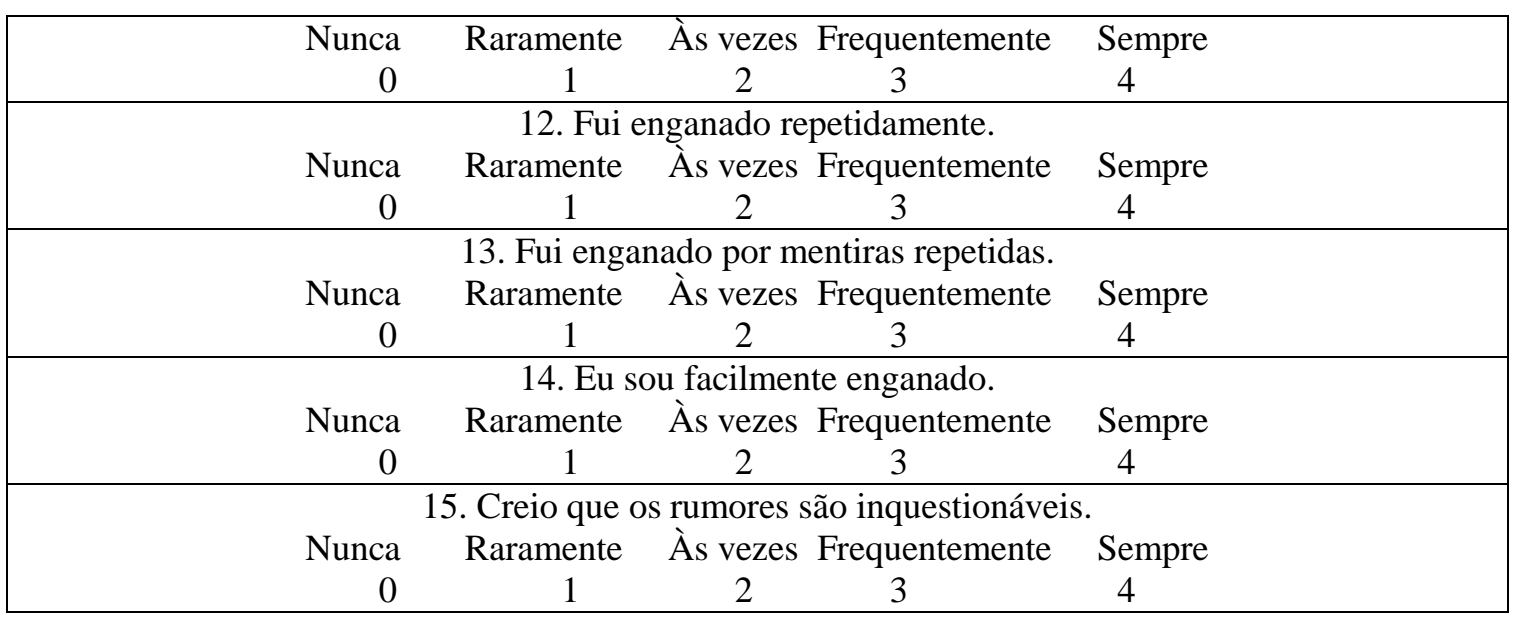

\section{Anexo J \\ DADOS SOCIODEMOGRÁFICOS FASE 1}

\section{Gênero *}

Marcar apenas uma oval.

Feminino

Masculino

Outro

2. Ano de nascimento (ex.: 1952) *

3. Em qual estado do Brasil você vive: *

Acre (AC)

Alagoas (AL)

Amapá (AP)

Amazonas (AM)

Bahia (BA)

Ceará (CE)

Distrito Federal (DF)

Espírito Santo (ES)

Goiás (GO)

Maranhão (MA)

Mato Grosso (MT)

Mato Grosso do Sul (MS)

Minas Gerais (MG)

Pará (PA)

Paraíba (PB)

Paraná (PR)

Pernambuco (PE)

Piauí (PI)

Rio de Janeiro (RJ)

Rio Grande do Norte (RN)

Rio Grande do Sul (RS)

Rondônia (RO)

Roraima (RR) 
Santa Catarina (SC)

São Paulo (SP)

Sergipe (SE)

Tocantins (TO)

Outro país

4. Qual o seu nível educacional *

Primário completo

Secundário completo

Universitário completo

Pós-graduação completa (Mestrado, Doutorado)

Outro:

5. Ocupação principal *

Autônomo

Empregado

Estudante

Desempregado

Aposentado

Profissional da saúde

Profissional da saúde atuando no combate à COVID-19

Outro:

6. Na semana passada, eu, principalmente

Trabalhei no local que usualmente trabalho

Trabalhei em casa

Não trabalhei devido à Covid-19 ou por causa de restrições legais proibindo movimento (mas, permaneço empregado)

Perdi meu emprego desde a pandemia da Covid-19 pela implementação do controle de movimentação pelas autoridades locais

Desempregado antes da pandemia da Covid-19 ou implementação de controle de movimentos pelas autoridades locais

Outro:

7. Número de crianças abaixo de 18 anos de idade que moram em casa *

8. Você fez teste clínico para a Covid-19?*

Sim Não

9. Você conhece alguém que contraiu a Covid-19? *

Sim Não Não tenho certeza disso

10. Se você conhece alguém que contraiu a Covid-19, qual a sua relação com ele(a)? *

É um morador da casa

É um parente, mas não mora na mesma casa

É um amigo próximo

É um colega de trabalho ou escola (universidade)

É um vizinho

Não se aplica

11. Você foi infectado com a Covid-19? *

Sim Não Não sei

12. Você tem se automedicado para a Covid-19? *

Sim Não

13. Você tem alguma doença crônica? *

Sim Não Não sei

14. Você faz uso de automedicação? * 
Sim Não

15. Você já foi vacinado contra alguma doença infecciosa? (Vacinas obrigatórias: BCG; DTP e HIB; Hepatite B; Pneumocócica 10; VOHR; VOP; Meningocócica C; SCR ou Tríplice Viral) *

Sim Não Não sei

16. Se tem filhos, os leva para vacinar? (Vacinas obrigatórias) *

Sim Não Não se aplica

17. Se você é adulto ou idoso, vacina-se todo ano contra a gripe? *

Sim Não Não sei

18. Na semana passada, quantas horas você se exercitou? Note que a escala possui o número 0 (não se exercitou) e vai de 1 ao 10, que correspondem a quantidade total de horas somando-se todos os dias da semana. *

não me exercitei $0 \begin{array}{llllllllll}1 & 2 & 3 & 4 & 5 & 6 & 7 & 8 & 9 & 10\end{array}$

19. Na semana passada, quantos dias você foi ao local de seu trabalho? *

20. Na semana passada, em média, quantas horas por dia você trabalhou em casa? *

21. Considerando a situação atual, informe-nos sobre a probabilidade de você pensar (o quanto atualmente você acredita nisso), que será infectado pela Covid-19 em um futuro próximo *

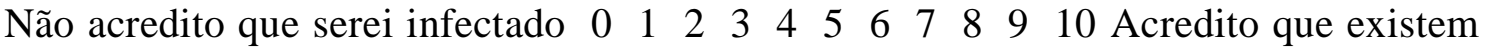
muitas chances de eu ser infectado num futuro próximo

22. Considerando a situação atual, informe-nos sobre a probabilidade de você pensar (o quanto atualmente você acredita nisso), que um de seus familiares poderá ser infectado pela Covid-19 em um futuro próximo *

Não acredito que serão infectados $\begin{array}{lllllllllll}0 & 1 & 2 & 3 & 4 & 5 & 6 & 7 & 8 & 9 & 10 \\ \text { Acredito que existem }\end{array}$ muitas chances de serem infectados num futuro próximo

23. Considerando a situação atual, informe-nos sobre a probabilidade de você pensar (o quanto atualmente você acredita nisso), que algum de seus colegas ou amigos poderá ser infectado pela Covid-19 em um futuro próximo *

Não acredito que serão infectados $1 \begin{array}{llllllllll}1 & 2 & 3 & 4 & 5 & 6 & 7 & 8 & 9 & \text { 10Acredito que existem }\end{array}$ muitas chances de serem infectados num futuro próximo

24. Se você trabalha, qual é o porte de sua empresa ou companhia? *

MEI (Microempreendendor Individual)

Micro empresa

Média empresa

Grande Empresa

Não estou trabalhando

Outro:

25. Geralmente, quantas vezes você sai de casa por dia? *

26. Na semana passada, eu passei ....... horas por dia na internet, celular ou telefone, tablet e/ou laptop (Responda com o número de horas) *

27. Na semana passada, eu gastei ....... horas por dia na mídia social (ex.: Whatsapp, Facebook, Instagram, Twitter, Youtube) - Responda com o número de horas. *

28. Na semana passada, eu gastei ....... horas por dia na busca de informações relacionadas à Covid-19 na mídia social (ex.: Whatsapp, Facebook, Instagram, Twitter, Youtube) - Responda com o número de horas.

29. De qual cidade/estado e país você preencheu estes dados? 


\section{ANEXO K \\ TERMO DE CONSENTIMENTO LIVRE E ESCLARECIDO}

Você está sendo convidado a participar no Módulo VII do projeto de pesquisa intitulado "Reações Físicas, Cognitivas e Psicológicas ao COVID19. Neste módulo, cujos temas são hesitação à vacina, inteligência social e autoavaliada, e vulnerabilidade social e à doença, você responderá às seguintes escalas: 1-Inventário de Personalidade Narcisista (IPN) - 16; 2- Escala de Auto-Relato de Credulidade; 3- Escala de Percepção à Vulnerabilidade à Doença Infecciosa; 4- Escala de de Aderência às Teorias Conspiratórias Anti-Vacina; 5- Escala de Atitudes Anti-Vacinação. Pode ser que que você já tenha colaborado com os módulos anteriores, mas sua participação neste módulo também é muito importante. Este projeto é fruto da colaboração que envolve um grupo pesquisadores brasileiros oriundos de diversas universidades públicas e um grupo de pesquisadores estrangeiros interessados nos efeitos do impacto e nos estados psicológicos variados provocados pela rápida propagação da Covid-19 ao redor do mundo, especialmente no Brasil. Caso você concorde em participar, responderá algumas perguntas por meio de um formulário eletrônico que levará em média 20 minutos do seu tempo para colaborar com esta pesquisa. Sua participação, é gratuita e voluntária. Por isso, a qualquer momento, você poderá desistir de participar da pesquisa. Sua identidade e seus dados serão mantidos em sigilo e suas respostas serão utilizados somente nesta pesquisa por meio de relatórios materiais bibliográficos, artigos e eventos científicos sem trazer qualquer prejuízo, situação de risco ou danos aos participantes. 
Ao acessar os questionários você verá que pode decidir responder ou não a estes. Se continuar, por favor, entenda que não há resposta correta, boa ou ruim. Todas são importantes. A tarefa que você irá realizar não é difícil de ser completada e, simplesmente, requer que você leia atentamente as questões (itens) de cada questionário, ou escala, e, em seguida, circule a categoria numérica que melhor reflita o seu comportamento, ou atitude, em relação a aquela atividade descrita. Cada questionário está apresentado separadamente nas folhas seguintes aos dados demográficos. Pedimos a gentileza de não deixar qualquer item (questão) sem resposta. Siga as instruções de cada questionário e assinale a cada questão uma categoria de resposta como solicitada. Quanto aos benefícios, acreditamos que a participação de todos possibilitará o desenvolvimento maior consciência dos aspectos da sua saúde através de um processo de reflexão e, consequentemente, na melhora na qualidade de vida por meio da autopercepção.

Durante toda a pesquisa você tem o direito de tirar suas dúvidas com os pesquisadores que estarão à disposição para qualquer esclarecimento por meio do endereço eletrônico gpsicovid@gmail.com ou no endereço Av. Bandeirantes, 3900 - Vila Monte Alegre, Ribeirão Preto - SP.

É importante que você saiba que esta pesquisa está de acordo com os preceitos éticos e foi submetida ao CONEP - Comissão Nacional de Ética em Pesquisa, o órgão institucional que tem por objetivo analisar os aspectos éticos e junto com o CEP Comitê de Ética em Pesquisa que visa proteger o bem-estar dos indivíduos pesquisados. Número de aprovação do projeto: 31703720.9.1001.0008. Este órgão pode ser consultado através dos contatos (61)3315-5877 E-mail: conep@ saude.gov.br Endereço: SRTVN 701, Via W 5 Norte, lote D - Edifício PO 700, $3^{\circ}$ andar - Asa Norte BRASILIA/DF.

Agradecemos desde já sua contribuição e participação!

\section{AO CLICAR EM ACEITAR VOCÊ INDICARÁ QUE CONCORDA EM PARTICIPAR DA PESQUISA E SE DESEJAR UM CÓPIA DESTE TERMO O MESMO PODERÁ SER OBTIDO ATRAVÉS DO EMAIL gpsicovid@gmail.com}




\begin{abstract}
ANEXO L
Você está sendo convidado a participar no Módulo VIII do projeto de pesquisa intitulado "REAÇÕES FÍSICAS, PSICOLÓGICAS E COGNITIVAS À COVID-19". Neste módulo, cujos temas são hesitação à vacina, inteligência social e autoavaliada, e vulnerabilidade social e à doença, você responderá às seguintes escalas: 1-Escala d Hesitação à Vacina; 2- Escala de Inteligência autoavaliada; 3- Escala de Inteligência Social Autoavaliada; 4- Escala de Vulnerabilidade Social; 5- Escala de Percepção Vulnerabilidade às doenças infecciosas. Pode ser que que você já tenha colaborado com os módulos anteriores, mas sua participação neste módulo também é muito importante. Este projeto é fruto da colaboração que envolve um grupo pesquisadores brasileiros oriundos de diversas universidades públicas e um grupo de pesquisadores estrangeiros interessados nos efeitos do impacto e nos estados psicológicos variados provocados pela rápida propagação da Covid-19 ao redor do mundo, especialmente no Brasil. Caso você concorde em participar, responderá algumas perguntas por meio de um formulário eletrônico que levará em média 20 minutos do seu tempo para colaborar com esta pesquisa. Sua participação, é gratuita e voluntária. Por isso, a qualquer momento, você poderá desistir de participar d pesquisa. Sua identidade e seus dados serão mantidos em sigilo e suas respostas serão utilizados somente nesta pesquisa por meio de relatórios materiais bibliográ;cos, artigos e eventos cientí;cos sem trazer qualquer prejuízo, situação de risco ou danos aos participantes.
\end{abstract}


Ao acessar os questionários você verá que pode decidir responder ou não a estes. Se continuar, por favor, entenda que não há resposta correta, boa ou ruim. Todas são importantes. A tarefa que você irá realizar não é difícil de ser completada e, simplesmente, requer que você leia atentamente as questões (itens) de cada questionário, ou escala, e, em seguida, circule a categoria numérica que melhor reflita o seu comportamento, ou atitude, em relação a aquela atividade descrita. Cada questionário está apresentado separadamente nas folhas seguintes aos dados demográficos. Pedimos a gentileza de não deixar qualquer item (questão) sem resposta. Siga as instruções de cada questionário e assinale a cada questão uma categoria de resposta como solicitada. Quanto aos benefícios, acreditamos que a participação de todos possibilitará o desenvolvimento maior consciência dos aspectos da sua saúde através de um processo de reflexão e, consequentemente, na melhora na qualidade de vida por meio da autopercepção.

Durante toda a pesquisa você tem o direito de tirar suas dúvidas com os pesquisadores que estarão à disposição para qualquer esclarecimento por meio do endereço eletrônico gpsicovid@gmail.com ou no endereço Av. Bandeirantes, 3900 - Vila Monte Alegre, Ribeirão Preto - SP.

É importante que você saiba que esta pesquisa está de acordo com os preceitos éticos e foi submetida ao CONEP - Comissão Nacional de Ética em Pesquisa, o órgão institucional que tem por objetivo analisar os aspectos éticos e junto com o CEP Comitê de Ética em Pesquisa que visa proteger o bem-estar dos indivíduos pesquisados. Número de aprovação do projeto: 31703720.9.1001.0008. Este órgão pode ser consultado através dos contatos (61)3315-5877 E-mail: conep@saude.gov.br Endereço: SRTVN 701, Via W 5 Norte, lote D - Edifício PO 700, $3^{\circ}$ andar - Asa Norte BRASILIA/DF.

Agradecemos desde já sua contribuição e participação!

\section{AO CLICAR EM ACEITAR VOCÊ INDICARÁ QUE CONCORDA EM PARTICIPAR DA PESQUISA E SE DESEJAR UM CÓPIA DESTE TERMO O MESMO PODERÁ SER OBTIDO ATRAVÉS DO EMAIL gpsicovid@gmail.com}




\section{ANEXO M}

1. Gênero *

Marcar apenas um.

Feminino

Masculino

Outro

2. Ano de nascimento (ex.: 1952)*

3. Em qual estado do Brasil você vive: * Marcar apenas um.

Acre (AC)

Alagoas (AL)

Amapá (AP)

Amazonas (AM)

Bahia (BA)

Ceará (CE)

Distrito Federal (DF)

Espírito Santo (ES)

Goiás (GO)

Maranhão (MA)

Mato Grosso (MT)

Mato Grosso do Sul (MS)

Minas Gerais (MG)

Pará (PA)

Paraíba (PB)

Paraná (PR)

Pernambuco (PE)

Piauí (PI)

Rio de Janeiro (RJ)

Rio Grande do Norte (RN)

Rio Grande do Sul (RS) 
Rondônia (RO)

Roraima (RR)

Santa Catarina (SC)

São Paulo (SP)

Sergipe (SE)

Tocantins (TO)

Outro país

4. Qual o seu nível educacional *

Marcar apenas um.

Ensino Fundamental completo

Ensino Médio completo

Ensino Superior completo

Pós-graduação completa (Mestrado, Doutorado)

Outro:

5. Ocupação principal *

Marcar apenas um.

Autônomo

Empregado

Estudante

Desempregado

Aposentado

Profissional da saúde

Profissional da saúde atuando no combate à COVID-19

Outro:

6. Na semana passada, eu, principalmente *

Marcar apenas um.

Trabalhei no local que usualmente trabalho

Trabalhei em casa

Não trabalhei devido à Covid-19 ou por causa de restrições legais proibindo os deslocamentos (mas, permaneço empregado)

Perdi meu emprego desde a pandemia da Covid-19 pela implementação do controle de deslocamentos pelas autoridades locais

Desempregado antes da pandemia da Covid-19 ou implementação de controle de deslocamentos pelas autoridades locais

Outro:

7. Número de crianças abaixo de 18 anos de idade que moram em casa *

8. Você fez teste clínico para a Covid-19? *

Marcar apenas uma oval.

Sim

Não

9. Você conhece alguém que contraiu a Covid-19? *

Marcar apenas uma oval.

Sim

Não 
Não tenho certeza disso

10. Se você conhece alguém que contraiu a Covid-19, qual a sua relação com ele(a)? * Marcar apenas uml.

É um morador da casa

É um parente, mas não mora na mesma casa

É um amigo próximo

É um colega de trabalho ou escola (universidade)

É um vizinho

Não se aplica

11. Você foi infectado com a Covid-19? *

Marcar apenas um.

Sim

Não

Não sei

12. Se você teve a Covid-19, você está percebendo que houve alguma alteração na sua saúde mental ou nos seus comportamentos rotineiros?

Marcar apenas um.

Sim

Não

13. Se você teve Covid-19, você tem percebido alguma alteração cognitiva que não tinha antes? (Marque todas as opções que você identificou)

Dificuldade de concentração

Comprometimento no raciocínio

Alterações na qualidade da memória

Dificuldades motoras (controle da força muscular ou dos movimentos)

Insônia

Perda do olfato ou paladar

Não percebi alterações

14. Você tem se automedicado para a Covid-19? $*$

Marcar apenas um.

Sim

Não

15. Você tem alguma doença crônica? *

Marcar apenas um.

Sim

Não

Não sei

16. Você faz uso de automedicação? *

Marcar apenas uma oval.

Sim

Não 
17. Você já foi vacinado contra alguma doença infecciosa? (Vacinas obrigatórias: BCG; DTP e HIB; Hepatite B; pneumocócica 10; VOHR; VOP; Meningocócica C; SCR ou Tríplice Viral) *

Marcar apenas um.

Sim

Não

Não sei

18. Se tem filhos, os leva para vacinar? (Vacinas obrigatórias) *

Marcar apenas um.

Sim

Não

Não se aplica

19. Se você é adulto ou idoso, vacina-se todo ano contra a gripe? *

Marcar apenas um.

Sim

Não

Não sei

20. Você irá se vacinar contra a COVID-19? *

Marcar apenas um.

Sim

Não

21. A origem da vacina (país e/ou laboratório) contra a COVID-19 tem influência na sua decisão para se vacinar? *

Marcar apenas um.

Sim

Não

22. Na semana passada, quantas horas você se exercitou? Note que a escala possui o número 0 (não se exercitou) e vai de 1 ao 10, que correspondem a quantidade total de horas somando-se todos os dias da semana. *

não me exercitei $\begin{array}{lllllllllll}0 & 1 & 2 & 3 & 4 & 5 & 6 & 7 & 8 & 9 & 10 \text { horas ou mais }\end{array}$

23. Na semana passada, quantos dias você foi ao local de seu trabalho?

24. Na semana passada, em média, quantas horas por dia você trabalhou em casa? *

25. Considerando sua vida durante o período de pandemia, você se sente: *

Marcar apenas uma oval.

Feliz

Pouco feliz

Não mudou nada

Muito Infeliz

26. Você sentiu que houve alguma modificação emocional durante a pandemia? * Marcar apenas um. 
Sim, porém temporárias

Sim, duradouras

Não ocorreram alterações emocionais durante a pandemia

27. Você sentiu fadiga durante o período pandêmico? *

Marcar apenas uma oval.

Muita fadiga

Pouca fadiga

Não senti

28. Considerando a situação atual, informe-nos sobre a probabilidade de você pensar (o quanto atualmente você acredita nisso), que será infectado pela Covid-19 em um futuro próximo *

Marcar apenas uma oval.

Não acredito que serei infectado $1 \begin{array}{llllllllll}1 & 2 & 3 & 4 & 5 & 6 & 7 & 8 & 9 & 10 \\ \text { Acredito que existem }\end{array}$ muitas chances de eu ser infectado num futuro próximo

29. Considerando a situação atual, informe-nos sobre a probabilidade de você pensar (o quanto atualmente você acredita nisso), que um de seus familiares poderá ser infectado pela Covid-19 em um futuro próximo *

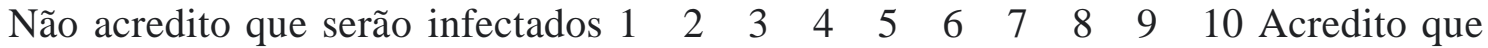
existem muitas chances de serem infectados num futuro próximo

30. Considerando a situação atual, informe-nos sobre a probabilidade de você pensar (o quanto atualmente você acredita nisso), que algum de seus colegas ou amigos poderá ser infectado pela Covid-19 em um futuro próximo *

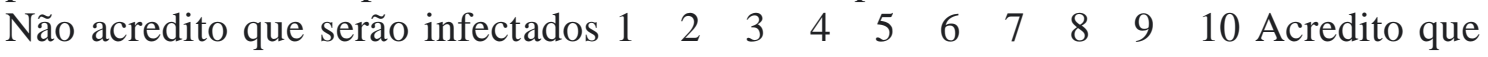
existem muitas chances de serem infectados num futuro próximo

31. Se você trabalha, qual é o porte de sua empresa ou companhia? *

Marcar apenas uma oval.

MEI (Microempreendendor Individual)

Micro empresa

Média empresa

Grande Empresa

Não estou trabalhando

Outro:

32. Mesmo após 10 meses de pandemia, você ainda se mantém em isolamento social? *

Marcar apenas um.

Sim

Não

33. Geralmente, quantas vezes você sai de casa por dia? *

34. Na semana passada, eu passei horas por dia na internet, celular ou telefone, tablet e/ou laptop (Responda com o número de horas por dia) *

35. Na semana passada, eu gastei ...... horas por dia na mídia social (ex.: Whatsapp, Facebook, Instagram, Twitter, Youtube) - Responda com o número de horas por dia. * 
36. Na semana passada, eu gastei horas por dia na busca de informações relacionadas à Covid-19 na mídia social (ex.: Whatsapp, Facebook, Instagram, Twitter, Youtube) - Responda com o número de horas por dia. *

37. De qual cidade/ país você preencheu estes dados?

\section{ANEXO N \\ TERMO DE CONSENTIMENTO LIVRE E ESCLARECIDO}

Você está sendo convidado a participar no Módulo12 do projeto de pesquisa intitulado "Reações Físicas, Cognitivas e Psicológicas ao COVID19. Várias nações no mundo e, particularmente, o Brasil estão vivenciando uma segunda onda da pandemia da Covid19. Ao longo da primeira onda investigamos várias reações psicológicas à Covid-19, incluindo hesitação, atitudes e comportamentos de aderência a vacinas e outras reações afetivas, cognitivas e comportamentais relacionadas à Pandemia. Agora, ao longo da segunda onda, especificamente, neste módulo 12, estamos interessados em saber a posição do brasileiro em relação à vacina da Covid-19. Neste módulo você responderá às seguintes escalas: 1- Escala de Atitudes Anti-Vacinação; 2-Escala de Aderência às Atitudes Conspiratórias Antivacina; 3- Escala de Hesitação à Vacina; e 4- Escala de Percepção à Vulnerabilidade à Doença Infecciosa. Pode ser que que você já tenha colaborado com os módulos anteriores, mas sua participação neste módulo também é muito importante. Este projeto é fruto da colaboração que envolve um grupo pesquisadores brasileiros oriundos de diversas universidades públicas e um grupo de pesquisadores estrangeiros interessados nos efeitos do impacto e nos estados psicológicos variados provocados pela rápida propagação da Covid-19 ao redor do 
mundo, especialmente no Brasil. Caso você concorde em participar, responderá algumas perguntas por meio de um formulário eletrônico que levará em média 15 minutos do seu tempo para colaborar com esta pesquisa. Sua participação, é gratuita e voluntária. Por isso, a qualquer momento, você poderá desistir de participar da pesquisa. Sua identidade e seus dados serão mantidos em sigilo e suas respostas serão utilizados somente nesta pesquisa por meio de relatórios materiais bibliográficos, artigos e eventos científicos sem trazer qualquer prejuízo, situação de risco ou danos aos participantes.

Ao acessar os questionários você verá que pode decidir responder ou não a estes. Se continuar, por favor, entenda que não há resposta correta, boa ou ruim. Todas são importantes. A tarefa que você irá realizar não é difícil de ser completada e, simplesmente, requer que você leia atentamente as questões (itens) de cada questionário, ou escala, e, em seguida, circule a categoria numérica que melhor reflita o seu comportamento, ou atitude, em relação a aquela atividade descrita. Cada questionário está apresentado separadamente nas folhas seguintes aos dados demográficos. Pedimos a gentileza de não deixar qualquer item (questão) sem resposta. Siga as instruções de cada questionário e assinale a cada questão uma categoria de resposta como solicitada. Quanto aos benefícios, acreditamos que a participação de todos possibilitará o desenvolvimento maior consciência dos aspectos da sua saúde através de um processo de reflexão e, consequentemente, na melhora na qualidade de vida por meio da autopercepção.

Durante toda a pesquisa você tem o direito de tirar suas dúvidas com os pesquisadores que estarão à disposição para qualquer esclarecimento por meio do endereço eletrônico gpsicovid@gmail.com ou no endereço Av. Bandeirantes, 3900 - Vila Monte Alegre, Ribeirão Preto - SP.

É importante que você saiba que esta pesquisa está de acordo com os preceitos éticos e foi submetida ao CONEP - Comissão Nacional de Ética em Pesquisa, o órgão institucional que tem por objetivo analisar os aspectos éticos e junto com o CEP Comitê de Ética em Pesquisa que visa proteger o bem-estar dos indivíduos pesquisados. Número de aprovação do projeto: 31703720.9.1001.0008. Este órgão pode ser consultado através do contatos (61)3315-5877 E-mail: conep@saude.gov.br Endereço: 
SRTVN 701, Via W 5 Norte, lote D - Edifício PO 700, $3^{\circ}$ andar - Asa Norte BRASILIA/DF.

Agradecemos desde já sua contribuição e participação!

AO CLICAR EM ACEITAR VOCÊ INDICARÁ QUE CONCORDA EM PARTICIPAR DA PESQUISA E SE DESEJAR UM CÓPIA DESTE TERMO O MESMO PODERÁ SER OBTIDO ATRAVÉS DO EMAIL gpsicovid@gmail.com

Pesquisadores responsáveis: Mayra Antonelli-Ponti; Scheila Paiva; Mariana Rezende Alves de Oliveira; José Aparecido Da Silva. 